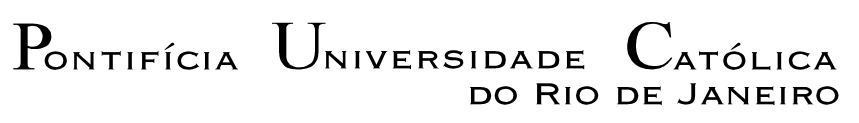

Felipe Martins Roballo Ferreira

Indicação e Dimensionamento de Trincas Aplicando Técnicas Tradicionais e Avançadas de Ensaios Não-Destrutivos

Dissertação de Mestrado

Dissertação apresentada como requisito parcial para obtenção do grau de Mestre pelo programa de Pós-graduação em Engenharia de Materiais e de Processos Químicos e Metalúrgicos da PUCRio.

Orientador: Prof. Marcos Venicius Soares Pereira

Rio de Janeiro

Setembro de 2018 


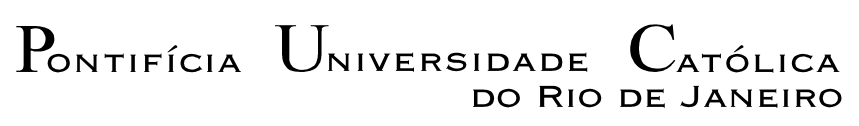

Felipe Martins Roballo Ferreira

\section{Indicação e Dimensionamento de Trincas Aplicando \\ Técnicas Tradicionais e Avançadas de \\ Ensaios Não-Destrutivos}

Dissertação apresentada como requisito parcial para obtenção do grau de Mestre pelo Programa de Pós-graduação em Engenharia de Materiais e de Processos Químicos e Metalúrgicos da PUCRio. Aprovado pela Comissão Examinadora abaixo assinada.

Prof. Marcos Venicius Soares Pereira

Orientador

Departamento de Engenharia Química e de Materiais - PUC-Rio

Prof. Fathi Aref Ibrahim Darwish

Departamento de Engenharia Civil - UFF

Prof. Ricardo Pondé Weber

Instituto Militar de Engenharia - IME

Prof. Ricardo Tadeu Lopes

Laboratório de Instrumentação Nuclear - COPPE/UFRJ

Prof. Marcio de Silveira Carvalho

Coordenador Setorial do Centro Técnico Científico - PUC-Rio 
Todos os direitos reservados. É proibida a reprodução total ou parcial do trabalho sem autorização do autor, do orientador e da universidade.

\section{Felipe Martins Roballo Ferreira}

Formado em Tecnico em Mecânica no CEFET-RJ (Centro Educacional Celso Suckow da Fonseca do Rio de Janeiro) em 2010. Graduou-se em Engenharia Mecanica na PUC-Rio (Pontifícia Universidade Católica do Rio de Janeiro) em 2016.

Ficha Catalográfica

\section{Ferreira, Felipe Martins Roballo}

Indicação e dimensionamento de trincas aplicando técnicas tradicionais e avançadas de ensaios não-destrutivos / Felipe Martins Roballo Ferreira ; orientador: Marcos Venicius Soares Pereira. - 2018. 83 f. : il. color. ; $30 \mathrm{~cm}$

Dissertação (mestrado)-Pontifícia Universidade Católica do Rio de Janeiro, Departamento de Engenharia Química e de Materiais, 2018.

Inclui bibliografia

1. Engenharia Química e de Materiais - Teses. 2. Aço DIN 42CrMo4. 3. Eixo virabrequim. 4. Ultrassom Phased Array. 5. Radiografia. 6. Time of Flight Diffraction e tomografia computadorizada. I. Pereira, Marcos Venicius Soares. II. Pontifícia Universidade Católica do Rio de Janeiro. Departamento de Engenharia Química e de Materiais. III. Título. 


\section{Agradecimentos}

Ao meu orientador, Prof. Marcos Venicius Soares Pereira pela oportunidade, pela excelente orientação durante a apresentação desse trabalho e pela amizade demonstrada nesse período.

A minha família, por me apoiar durante o período e por me proporcionar a melhor educação. Em especial à minha mãe Laise, minha noiva Isabelly e meu filho Thor, pela compreensão em momentos difíceis, incentivo e amor.

A PUC-Rio, pelo excelente ensino e instalações, sem os quais esta pesquisa não poderia ter sido realizada.

A empresa ENEVA, pelo apoio financeiro e suporte à pesquisa.

Aos colegas e amigos de mestrado, pelo convívio, estímulo e apoio.

A ARCtest pelo auxílio com experimentos de Ultrassom e Radiografia.

Ao Prof. Ricardo Tadeu Lopes, pelo auxilio com os experimentos de Radiografia Digital e Tomografia Computadorizada.

Ao José Marques pela paciência e trabalho nos corpos de prova.

Ao DEQM pelo ensino e disponibilidade das instalações para realização da pesquisa.

Pelo departamento de Engenharia Civil, por ceder equipamento para trincamento dos corpos de prova. 
Este trabalho foi desenvolvido no âmbito do Programa de Pesquisa e Desenvolvimento Tecnológico do Setor de Energia Elétrica regulado pela ANEEL, com o apoio das empresas ENEVA - Pecém II Geração de Energia S.A., Itaqui Geração de Energia S.A. e Parnaíba I, II e III Geração de Energia S.A. 


\section{Resumo}

Ferreira, Felipe Martins Roballo; Pereira, Marcos Venicius Soares. Indicação e Dimensionamento de Trincas Aplicando Técnicas Tradicionais e Avançadas de Ensaios Não-Destrutivos. Rio de Janeiro, 2018. 83p. Dissertação de Mestrado - Departamento de Engenharia Quimica e de Materiais, Pontifícia Universidade Católica do Rio de Janeiro.

Os Ensaios Não-Destrutivos são técnicas utilizadas na inspeção de materiais e equipamentos sem dano a integridade física, podendo ser executados nas etapas de pós-fabricação, montagem, operação e manutenção. São utilizados pela indústria como ferramenta de controle e garantia da qualidade de materiais, produtos e processos. Esta pesquisa teve como objetivo identificar trincas e estimar o seu comprimento em corpos de prova de aço DIN 42CrMo4, adotando diferentes técnicas de END. Os corpos de prova foram de um eixo virabrequim de um motor Diesel, utilizado como unidades geradora em usinas termoelétricas, que falhou por fadiga de baixo ciclo. Os corpos de prova foram projetados de acordo com as normas ASTM E1820, ASTM E1290 e ISO 15653, bem como adotando sugestões de inspetores de ultrassom quanto a uma geometria que otimizasse a eficiência das medições. Subsequente ao trincamento dos corpos de prova em fadiga, os mesmos foram inspecionados com o emprego das técnicas de Radiografia Digital (RD), Ultrassom Phased Array (UT-PA), métodos Pulso-Eco (PE) e Time os Flight Diffraction (TfOD), e Tomografia Computadorizada (TC). Em sequência, os corpos de prova foram fraturados com o uso de uma carga em flexão e nitrogênio liquido, o que permitiu a medição real dos comprimentos das trincas. As técnicas de UTPA, RD e TC indicaram tamanhos de trincas próximos entre si. Nos métodos de PE e ToFD, de UT-PA, se observou que a indicação das trincas sofre influência da distancia entre o cabeçote do equipamento e a posição da trinca. Em trincas menores, essa influência é mais acentuada, levando a uma medição errônea do comprimento da trinca. A técnica de RD apresentou um bom resultado da medida lateral da trinca, porem foi necessário um processamento digital da imagem para obtenção de melhores resultados, explicado devido a sensibilidade do ensaio à 
geometria do corpo de prova e da densidade do material utilizado. Já a TC apresentou imagens melhores e medidas de trinca similares se comparada com a $\mathrm{RD}$, o que pode influenciar em outros tipos/dimensões de defeitos. Em compensação, sofre mais influencia do volume de material presente no entorno do defeito, o que impossibilitou a detecção de defeitos em algumas amostras.

\section{Palavras-chave}

Aço DIN 42CrMo4; eixo virabrequim; Ultrassom Phased Array; Radiografia; Time of Flight Diffraction e Tomografia Computadorizada. 


\section{Abstract}

Ferreira, Felipe Martins Roballo; Pereira, Marcos Venicius Soares (Advisor). Indication and Measurement of Cracks Applying Traditional and Advanced Non-Destructive Testing Techniques. Rio de Janeiro, 2018. 83p. Dissertação de Mestrado - Departamento de Engenharia Quimica e de Materiais, Pontifícia Universidade Católica do Rio de Janeiro.

Non-Destructive Testing (NDT) are techniques applied to materials and equipment inspection without integrity degradation and can be performed in the post-manufacture, assembly, operation and maintenance stages. Those techniques are used by the industry to control a guarantee the quality of materials, products and processes. The aim of this research was to identify cracks and estimate their length on DIN 42CrMo4 steel specimens adopting different NDT techniques. The material to the test specimen was taken from a crankshaft of a Diesel engine, utilized as generating units in thermoelectric power plant, which has failed due to low cycle fatigue. The test specimen were designed according to ASTM E1820, ASTM E1290 and ISO 15653 standards, as well as suggestions made by NDT inspectors for a geometry that optimized the efficiency of the measurement. Subsequent to the fatigue induced crack on the specimens, they were inspected using, Digital Radiography (RD), Phased Array Ultrasound (UT-PA), Pulse-Echo (PE) and Time of Flight Diffraction (ToFD) methods, and Digital Tomography (TC). The specimens were then fractured with a bending load and liquid nitrogen, which allowed the measurement of the real crack length. UT-PA, PE and ToFD, and RD techniques showed a closer estimate crack size among then. It was observed that both UT-PA methods, PE and ToFD, presented an influence of the distance between the equipment head and the crack position, on the crack measurement. This was more pronounced in smaller cracks, leading to an erroneous measurement of the crack length. The RD technique presented a good a good result of lateral crack length, but a good digital image processing was necessary to obtain these results, explained by the sensitivity of the test to the geometry to the geometry of the specimen and to the material density. TC presented better imaging and similar 
lateral crack lengths when compared to RD, which could influence the detection of other types/dimensions of defects. In contrast, it is more influenced by the volume of material around the object, which made it impossible to detect defects in some samples.

\section{Keywords}

DIN 42CrMo4 Steel; Crankshaft; Radiography; Phased Array Ultrasound; Time of Flight Diffraction and Digital Tomography 


\section{Sumário}

$\begin{array}{ll}\text { 1. Introdução } & 17\end{array}$

2. Revisão bibliográfica 19

2.1. Ensaios Não Destrutivos 19

2.2. Ensaio por Ultrassom 19

2.2.1. Princípio Físico 20

2.2.2. Ondas Sonoras 22

2.2.3. Modo de Propagação das Ondas 23

2.2.4. Ondas Longitudinais 24

2.2.5. Ondas Transversais 24

2.2.6. Ondas Superficiais 25

2.2.7. Atenuação Sonora 26

2.2.8. Impedância Acústica 26

2.2.9. Geração de Ondas Ultrasônicas 27

2.3. Ultrassom Phased Array 29

2.3.1 Tipos de Representação Gráfica 30

2.4. Técnicas de Inspeção por Ultrassom Phased Array 33

2.4.1. Pulso-Eco 34

2.4.2. TANDEM 35

2.4.3. Time of Flight Diffraction 35

2.5. Ensaio Radiográfico 36

2.5.1. Princípios Físicos $\quad 37$

2.5.2. Fontes de Radiação 38

2.5.3. Radiografia Digital 39

2.5.4. Tomografia Computadorizada 40

3. Metodologia 42

3.1. Material 42

3.2. Corpos de Prova 42 
3.3. Nucleação e Propagação de Trincas 44

3.4. Técnicas de Ensaios Não-Destrutivos 46

3.4.1. Ultrassom Phased Array 46

3.5. Radiografia Digital 48

3.6. Tomografia Computadorizada 49

3.7. Fratura e Análise dos Corpos de Prova 51

4. Resultados e discussão

4.1. Medição Visual dos Tamanhos de Trinca 52

4.2. Ultrassom Phased Array 53

4.3. Radiografia Digital 55

4.4. Tomografia Computadorizada 57

4.5. Comparação entre Técnicas 59

5. Conclusões 61

6. Sugestões para trabalhos futuros 62

7. Referências bibliográficas 63

8. Anexos 65

Anexo 01 - Medição das Trincas: 66

Anexo 02 - Resultados UT-PA: $\quad 67$

$\begin{array}{ll}\text { Anexo } 03 \text { - Resultados da RD: } & 79\end{array}$

Anexo 04 - Resultados da TC: $\quad 81$ 


\section{Lista de Figuras}

Figura 1 - Ensaio de ultrassom e visualização por A-scan

[Berke, 2017].

Figura 2 - Espectro sonoro. 23

Figura 3 - Diferentes tipos de estrutura atômica [VIEIRA, 2013]. 23

Figura 4 - llustração de onda longitudinal [Berke, 2005]. 24

Figura 5 - Ilustração de uma onda transversal [Berke, 2005].

Figura 6 - llustração dos tipos [Berke, 2005]. 25

Figura 7 - Refração e reflexão da onda incidente. 27

Figura 8 - Ilustração dos tipos de transdutors de ultrassom [Andreucci, 2017]. 28

Figura 9 - Equipamento controlador OmniScan MX-2 para UT-PA. 29

Figura 10 - Exemplo detecção de trinca por A-scan [Richter, 2007]. 30

Figura 11 - Exemplo de um defeito em material polimerico por B-scan [Andreucci, 2017].

Figura 12 - Resultado da inspeção de uma solda por C-Scan

[Andreucci, 2017].

Figura 13 - Resultado em S-scan de um material com trinca

[Andreucci, 2017].

Figura 14 - Desenho das representações possíveis para UT-PA

[Andreucci, 2017].

Figura 15 - Desenho esquematico da técnica ToFD e suas representações gráficas.

Figura 16 - Grafico do comprimento de ondas para diferentes tipos de ondas eletromagnéticas.

Figura 17 - Radiografia de uma solda com uma trinca e um poro. $\quad 38$

Figura 18 - Radiografia a) tradicional e b) digital de uma curva soldada. 40

Figura 19 - Desenho esquemático da geração de imagens da TC.

Figura 20 - Trinca em um bloco de alumínio (acima) e representação digital da trinca em 3D (Nilsson, 2014). 
Figura 21 - Eixo virabrequim de motor Diesel de termoelétrica.

Figura 22 - Geometria de corpo de prova adaptado à proposta pelo trabalho anterior.

Figura 23 - Detalhe de fabricação para a) ASTM E1820; e

b) ISO 15653 (dimensões em milímetros).

Figura 24 - Desenho esquemático do ensaio por flexão em três pontos (retirado da norma ASTM E1290 versão 2008).

Figura 25 - Visão geral da Máquina MTS 810-500 kN com corpo de prova CP01 posicionado para ensaio de fadiga por flexão.

Figura 26 - Foto do equipamento Omniscan MX2 utilizado com o software tomoview utilizado.

Figura 27 - Foto do corpo de prova com esquema da nomenclatura. $\quad 47$

Figura 28 - Desenho esquemático da inspeção pelo método de PE. 47

Figura 29 - Desenho esquemático da inspeção pelo método ToFD. 48

Figura 30 - Desenho esquemático do ensaio por RD. 49

Figura 31 - Sistema de microCT Phoenix VTomex, da fabricante GE. $\quad 50$

Figura 32 - Representação esquemática do processo de aquisição de imagens para TC.

Figura 33 - Superfície de fratura e medição das trincas para o CP04. 51

Figura 34 - ToFD dos CP01, itens (a) e (b); e CP02, itens (a) e (b); $\quad 55$

Figura 35 - Medida lateral da trinca do CP04. 56

Figura 36 - TC do CP04 pela a. vista lateral; b. corte longitudinal. $\quad 57$

Figura 37 - Gráfico com o valor de trinca mais entalhe pra todas as técnicas de END e o valor real da trinca.

Figura 38 - Gráfico com os valores de media lateral real da trinca e medida indicada pelas técnicas de TC e RD. 


\section{Lista de Tabelas}

Tabela 1 - Composição química do aço DIN 42CrMo4.

Tabela 2 - Comprimento de trinca inicial pretendido: $a_{0}=a_{\text {entalhe }}+a_{\text {fadiga }}$ e sua respectivas carga.

Tabela 3 - Medidas das trincas pela superficie de fratura.

Tabela 4 - Valores das trincas calculados, da media lateral, do entalhe e da trinca total.

Tabela 5 - Valores de trinca pelo método de PE, valor real e erro relativo.

Tabela 6 - Valores de trinca pelo método de ToFD, valor real e erro relativo.

Tabela 7 - Valor da medida lateral por RD da trinca, comparação com a medida lateral da trinca real e ao tamanho total da trinca.

Tabela 8 - Valor da medida lateral por TC da trinca, comparação com a medida lateral da trinca real e ao tamanho total da trinca. 


\section{Lista de Abreviaturas}

\begin{tabular}{|c|c|}
\hline ASTM & American Society Testing and Materials \\
\hline $\mathrm{CP}$ & Corpo de Prova \\
\hline CTOD & Crack Tip Opening Displacement \\
\hline DIN & Deutsche Institu für Normung \\
\hline END & Ensaio Não Destrutivo \\
\hline ISO & International Organization for Standartization \\
\hline NDT & Non Destructive Testing \\
\hline PA & Phased Array \\
\hline PE & Pulso-Eco \\
\hline $\mathrm{RD}$ & Radiografia Digital \\
\hline $\mathrm{TC}$ & Tomografia Computadorizada \\
\hline ToFD & Time of Flight Diffraction \\
\hline UT & Ultrassom \\
\hline
\end{tabular}




\section{Lista de Símbolos}

$\begin{array}{ll}\mathrm{P}_{\mathrm{adm}} & \text { Carga máxima admissível } \\ \mathrm{b}_{0} & \text { Espessura do CP descontada da trinca } \\ \mathrm{B} & \text { Largura do corpo de prova } \\ \sigma_{\mathrm{y}} & \text { Média das tensões de escoamento e resistência mecânica } \\ \mathrm{S} & \text { Espaçamento entra apoios } \\ \mathrm{P}_{\max } & \text { Carga máxima, equivalente a } 60 \% \text { da } \mathrm{P}_{\mathrm{adm}} \\ \mathrm{P}_{\min } & \text { Carga mínima, equivalente a } 10 \% \text { da } \mathrm{P}_{\mathrm{adm}} \\ \mathrm{R} & \text { Razão entre as cargas máxima e mínima } \\ \mathrm{P}_{0} & \text { Carga inicial } \\ \mathrm{P}_{\mathrm{i}} & \text { Carga para um tamanho de trinca i } \\ \text { aentalhe } & \text { Profundidade do entalhe } \\ \text { afadiga } & \text { Comprimento da trinca de fadiga } \\ \text { ao } & \text { Valor da soma do aentalhe com afadiga }\end{array}$




\section{Introdução}

A maior parte dos equipamentos industriais está sujeito a carregamentos cíclicos durante operação, sendo esse tipo de carregamento responsável por falhas de fadiga, pois permite nucleação e propagação de trincas sob cargas abaixo do limite de escoamento e da resistência mecânica. Essas trincas são concentradores de tensão severos, ocasionando falha por fadiga, que acontece a níveis de carregamento abaixo de limites normalmente usados para carregamentos não cíclicos (NDT Resource Center, 2013). Falha por fadiga é a falha mais recorrente em equipamento em operação (Einav, 2005), sendo o entendimento dos mecanismos de fadiga e o acompanhamento da trinca de extrema importância para evitar falha catastrófica do equipamento, gerando uma interrupção operacional e até a substituição do equipamento falhado, gerando um custo operacional enorme, além de possíveis acidentes nocivos ao meio ambiente e perdas humanas. Portanto é de extrema importância que se evite o aparecimento da trinca e, principalmente, que este seja acompanhado a fim de evitar uma falha catastrófica, porém ainda acarretaré em uma possível substituição do componente e custos operacionais de manutenção (Zhiliang, 2017).

Especificamente na indústria termoelétrica, o critério de projeto de vida infinita em fadiga, por exemplo, em válvulas e virabrequim, não é atendido. Isso decorre da nucleação e propagação de trincas por fadiga multiaxial.

Os métodos para medições de trincas de fadiga podem ser divididos em dois grupos, os de Ensaios Destrutivos e os Ensaios Não Destrutivos (END). Nos Ensaios Destrutivos é necessário acesso direto a superfície da trinca, o que acarreta em uma usinagem ou quebra do material, ou seja, acabam por afetar a integridade do equipamento e a inutilização do mesmo. Já os END são caracterizados por técnicas de analise não intrusivas ao material, mantendo a integridade do equipamento em sua plenitude (Andreucci, 2017).

As técnicas de END são muito valiosas pra indústria, pois permitem minimizar custo e tempo de manutenção e evitar acidentes industriais. Com isso mantem confiabilidade da operação e qualidade de produção. 
Entre os métodos de END estão "inspeção visual”, "ensaio de líquidos penetrantes", "inspeção por partículas magnéticas", inspeção por ultrassom e inspeção por radiografia. Mais especificamente, a técnica de Ultrassom pode ser realizada através de diversos métodos, como, por exemplo, ultrassom convencional, Phased Array, Pulso-Eco, etc. Por sua vez, a técnica de radiografia pode ser digitalizada, o que permite melhorar a qualidade da imagem caso necessário e, com equipamento e programas computacionais especificos, permitem uma superposição de imagens, denominada de Tomografia Computadorizada. Estas técnicas são as mais usuais, na indústria, para o dimensionamento de defeitos, tendo cada qual a suas vantagens e desvantagens. Essas técnicas auxiliam na tomada de decisão quanto a desqualificar ou qualificar soldas, equipamento, etc., manutenção ou substituição de equipamento, de parâmetros de operação para evitar falha/postergar à manutenção de equipamentos, entre outros (Andreucci, 2017).

O tópico de END tem sido assunto de muitos trabalhos de pesquisas que visam a um maior desenvolvimento dessas técnicas, com objetivo principal de se ter uma precisão e sensibilidade à detecção do defeito e custo de inspeção, podendo esses trabalhos serem de cunho cientifico ou diretamente tecnológico/industrial.

Este trabalho objetiva a avaliação experimental de corpos de prova de aço com trincas induzidas por fadiga, pelas técnicas de Radiografia Digital (RD), Tomografia Computadorizada (TC) e Ultrassom Phased Array (UT-PA), nos métodos de Pulso-Eco (PE) e Time of Flight Diffractioc (ToFD), e posterior comparação do resultados das técnicas com a medida real da trinca, obtida por um método destrutivo, e analise de assertividade dos END propostos. 


\section{Revisão bibliográfica}

\subsection{Ensaios Não Destrutivos}

END são, atualmente, o melhor método de análise da integridade de equipamentos, componentes estruturais e materiais na indústria, pois com a aplicação destas técnicas é possivel avaliar as propriedades mecânicas e avaliar defeitos de manufatura, antes e durante a operação, possibilitando asim um controle de qualidade e prevenções de falhas criticam, reduzindo custos por perdas materiais e humanas, multas e interrupção do processo (Andreucci, 2017).

O número de métodos de END que podem ser usados para inspecionar diversos tipos de equipamentos, materiais ou até mesmo para efetuar medições é grande e não para de crescer, pois pesquisadores continuam a descobrir novas formas de aplicação das teorias físicas e outras disciplinas científicas para desenvolver sofisticados métodos de END (Andreucci, 2017). Dentre os metodos mais utilizados estão à inspeção visual, liquidos penetrantes, ultrassom, radiografia, fuga de corrente e particulas maginéticas. Destes metodos, esse estudo visa aprofundar o conhecimento em ultrassom, pela técnica de ultrassom Phased Array, pelos metodos de Pulso-Eco e Time of Flight Diffraction (ToFD), e radiografia, pelos metodos de Radiografia Digital (RD) e Tomografia Computadorizada (TC), com o intuito de avaliar essas tecnicas quanto a aplicabilida de na inspeçãode trincas de fadiga.

\subsection{Ensaio por Ultrassom}

Este ensaio surgiu da necessidade de indentificar defeitos internos por métodos diferentes da radiografia, tanto raios X como Gama, devido a nocividade do ensaio por radiação. A Firestone, em 1942, estudou o princípio da eco-sonda para análise de componentes industrial, em pouco tempo o processo passou para a escala industrial, uma vez que, o UT se mostrou ser tão confiavel quanto a radiografia para a indicação de irregulaaridades internas, sem o õnus da severidade 
associado à radiação. A partir de então, a evolução das técnicas que se utilizam o principio do ultrassom é continua, e recorrentemente novas tecnologias são desenvolvidas, exemplo disso são as novas técnicas de Phased Array, Pulso-Eco e Time of Flight Difraction (TOFD). Atualmente, essas duas tecnicas estão em grande uso na indústria, atuando como verificador de qualidade de produção, analisando diversos tipos de irregularidades, e como principal responsavel na inspeção de equipamento e componentes mecânicos no sentido de degradação fisica e de propriedades, como trincas e corrosão (Berke, 2017).

A técnica consiste na indução de um feixe sonoro de alta frequência através de um aparato eletrônico, no equipamento em analise. $\mathrm{O}$ feixe sonoro sofre reflexões em interfaces da peça, uma vez que diferentes tipos de material, trincas, poros, inclusões diversas e falta de fusão agem como interfaces ao feixe sonoro. Assim, pode-se realizar a detecção de descontinuidades e determinar o seu tamanho, orientação e localização, alem de ser possível determinar espessura de material pela simples comparação de tempo entre as reflexões sonoras que ocorrem. Método esse que também pode ser utilizado para determinar diferenças de propriedades físicas e na estrutura do material.

\subsubsection{Princípio Físico}

O princípio básico dos ultrassons é baseado no fato de materiais sólidos serem bons condutores de ondas sonoras. A propagação das ondas sonoras na matéria segue princípios físicos simples, que é a transferencia do esforço mecânico em forma de onda de atomo a atomo, sendo a velocidade de propagação da onda constante e diferente para cada material, sendo relacionada com a rigidez da estrutura atômica, portanto um fator que possibilita medir irregularidades no material, que são para o ultrassom, uma diferença de impedância, o que gera uma reflexão na onda. Tambem é possivel descobrir o módulo de elasticidades avaliando a velocidade com que a onda se propaga no mesmo. A indução de frequências variáveis permite que seja selecionado o comprimento de onda adequado para a sensibilidade de detecção desejada. Quando temos um comprimento de onda menor a sensibilidade na detecção de pequenas descontinuidades é maior. A escolha da 
frequência é necessaria para adaptar o ensaio aos diferentes tipos de materiais e sua estrutura (NDT Resource Center, 2013).

No ensaio, o feixe sonoro é transmitido ao equipamento em análise através da produção de ondas sonoras por um cristal (piezoelétrico) que, excitado por um campo elétrico, provoca uma oscilação de volume no cristal, gerando assim ondas mecânicas com frequência igual à frequência de oscilação do cristal e da corrente ao qual ele está induzido. Ao ocorrer o retorno das ondas sonoras ao cristal, é gerado o efeito inverso, ou seja, a onda mecânica gera uma distribuição de cargas elétricas no cristal, criando um campo elétrico que é transmitido para o osciloscópio. O processo de inspeção é realizado de forma que o som produzido pelo transdutor é transmitido para o interior do material a ser inspecionado através de um acoplante que é colocado entre a sonda e a superfície do material, para preencher o gap entre as superficies com um material mais transmissor do que o ar, a fim de evitar uma reflexão severa logo no inicio da transmissão da onda. É normal que ocorra essa reflexão na superfície de contato e em outras superficies do material, conhecidos como ecos de fundo, que podem ser normatizadas no caso de uma inspeção Também ocorrem reflexões em defeitos ou descontinuidades (interfaces) presentes no material inspecionado. A reflexão do feixe sonoro é captada pelo transdutor e devido à diferença de sinais visualizados no osciloscópio é possível determinar que a peça se encontre com defeito. Esses feixes sonoros depois de transformados em impulsos elétricos são apresentados em um aparelho especifico (osciloscópio). A Figura 1 ilustra a técnica de contato pulso-eco, onde no visor existe o pulso inicial (face de contato do transdutor com a peça), o defeito e o eco de fundo (Berke, 2017). 


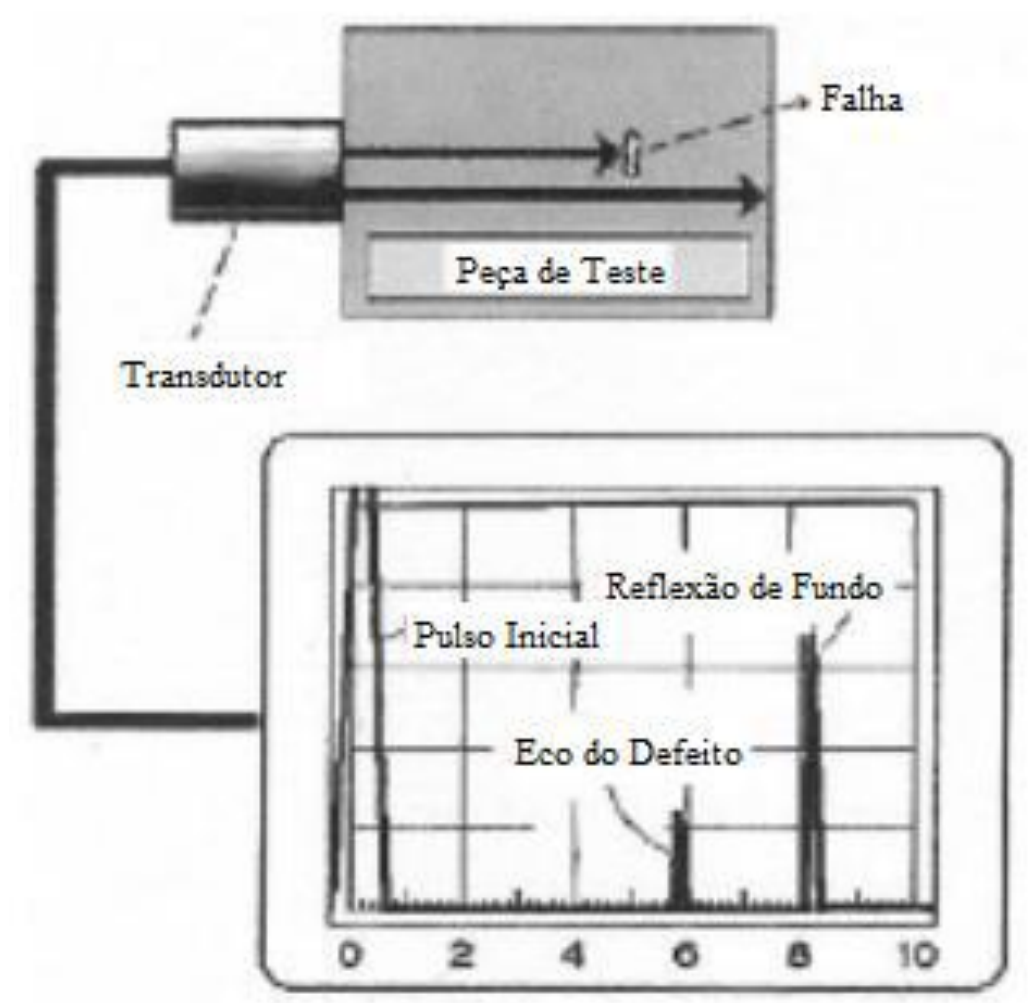

Figura 1 - Ensaio de ultrassom e visualização por A-scan (Berke, 2017).

\subsubsection{Ondas Sonoras}

Os sons (ondas sonoras) são sinonimos pra ondas criadas mecanicamente, ou seja, através de uma energia mecânica, conseguem se propagar pelo choque entre átomos, isto é, se propagam em sólidos, líquidos ou gases. Características do material, como seu módulo de elasticidade, a sua densidade assim como a frequência da onda sonora, podem influenciar positivamente ou negativamente nessa propagação. Como exemplo, o sistema auditivo humano consegue detectar ondas sonoras nas frequências entre $20 \mathrm{~Hz}$ e $20.000 \mathrm{~Hz}$. As ondas sonoras com frequências acima de $20.000 \mathrm{~Hz}$ são denominadas por ultrassom, como pode ser observado na Figura 2. As ondas sonoras seguem as regras físicas para ondas, como reflexão, difração e refração (Andreucci, 2017).

Nos sólidos, é possível ter diversos modos de propagação (tipos de onda) devido à possibilidade de se utilizar vários tipos de vibrações. Fundamentalmente o som pode se propagar através de três diferentes tipos de ondas: Ondas longitudinais, transversais e ondas superficiais, de Rayleith ou Creeping. 


\section{Frequência audivel}

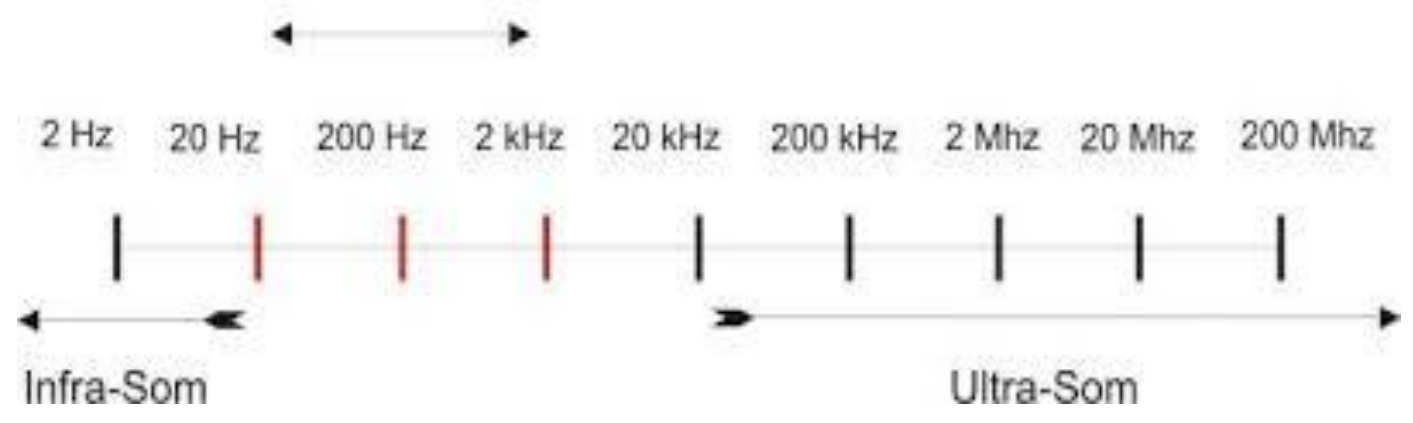

Figura 2 - Espectro sonoro.

\subsubsection{Modo de Propagação das Ondas}

A densidade dos materiais sólidos é muito maior se comparados com a densidade de líquidos ou gases, isso é, à distância interatômica é menor, além dos átomos se encontram organizados em uma rede cristalina, como se pode observar na Figura 3. Em razão destes dois fatores, o som consegue se propagar de formas mais eficiente nos materiais sólidos, atraves de diversos tipos de excitação, como as ondas longitudinais, transversais e de superfície, cada um com suas características especificas e principalmente com uma velocidade própria e impedâncias acústicas diferentes (NDT Resource Center, 2013).

\section{Gás}

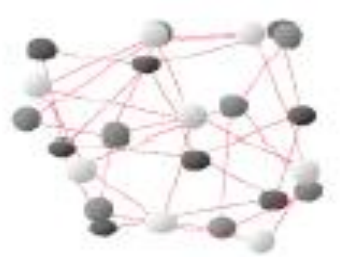

Líquido

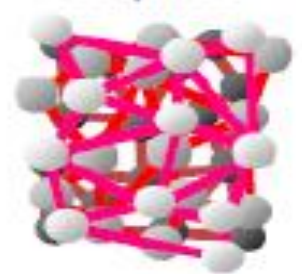

Sólido

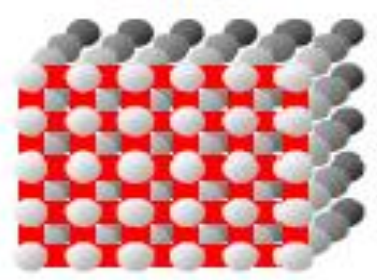

Figura 3 - Diferentes tipos de estrutura atômica (NDT Resource Center, 2013). 


\subsubsection{Ondas Longitudinais}

As ondas longitudinais são ondas de compressão-tração, pois a direção do deslocamento atômico imposto por elas é paralela à direção de propagação da onda, ou seja, a oscilação das partículas ocorre na mesma direção de propagação das ondas. Assim são criadas zonas de diferentes tamanhos entre as partículas, zonas de estiramento e compressão (Figura 4).

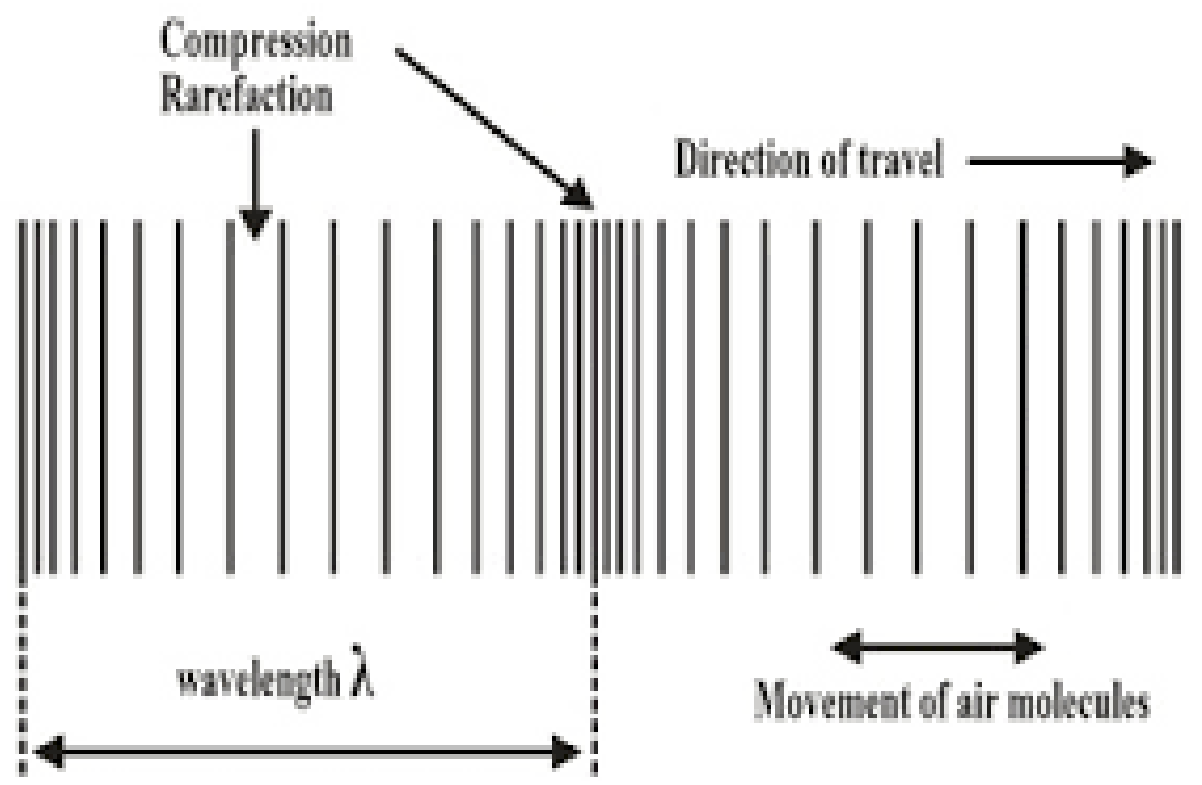

Figura 4 - Ilustração de onda longitudinal (Berke, 2017).

\subsubsection{Ondas Transversais}

As ondas transversais são ondas de corte, ou cisalhamento, nas quais a direção de vibração das partículas é perpendicular à direção de propagação da onda (Figura 5). Estas ondas não se propagam em gases ou líquidos e sua velocidade de propagação é de aproximadamente metade das ondas longitudinais. 


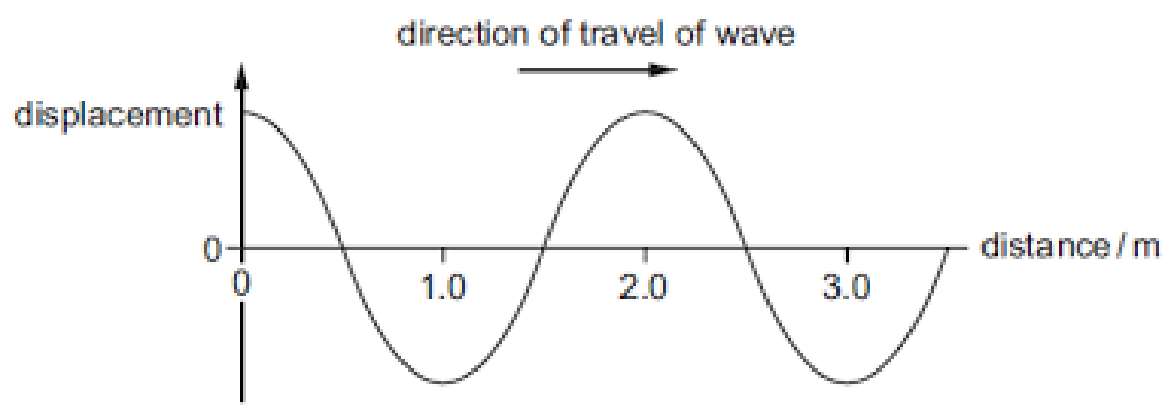

Figura 5 - Ilustração de uma onda transversal (Berke, 2017).

\subsubsection{Ondas Superficiais}

Esse tipo de onda tem como característica a propagação ao longo da interface de dois materiais com diferentes impedãncias, tendo profundidade equivalente ao seu comprimento de onda. Devido a essas caracteristicas pequenas trincas e descontinuidades superficiais conseguem ser detectadas na peça. Pode ser utilizada na inspeção de equipamentos com geometria complexa, contanto que seja avaliada as condições de reflexão nas extremidades, pois podem ser gerados sinais que atrapalhem na análise de resultados.

Há dois tipos de ondas superficiais: As ondas de Rayleigh, que são formadas por ondas transversais que se propagam na superfície e as ondas de Creeping, que são adquiridas pelas ondas longitudinais na superfície (Metals Handbook VOL 17). É possível observar, na Figura 6, a propagação de uma onda superficial Creeping.

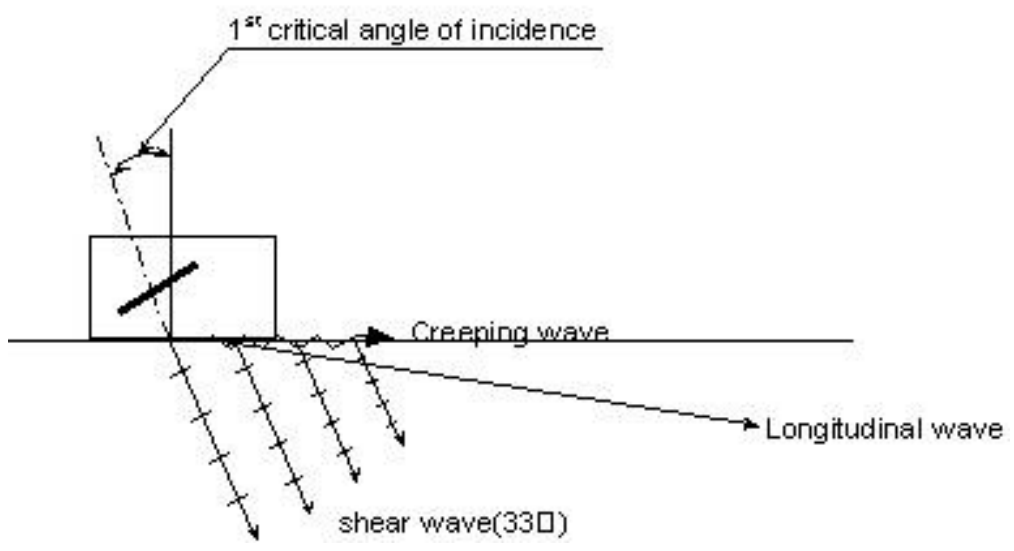

Figura 6 - Ilustração dos tipos (Berke, 2017). 


\subsubsection{Atenuação Sonora}

Baseia-se na diminuição da energia da onda, amplitude de oscilação em função do tempo, ou seja, diminuição da energia transmitida ao longo do termpo, diminuindo assim a intensidade do feixo sonoro á medida que a onda se propaga pelo material, o que faz com que, por exemplo, a intensidade do feixe sonoro que volta ao transdutor seja menor do que o feixe original. Esta redução é ocasionada pelos efeitos de dispersão, ocasionado pelas interfaces internas no material, como contornos de grãos, e absorção, quando o meio percorrido pela vibração acústica tem caráter elástico, fazendo com que parte da energia seja perdida na forma de calor (Andreucci, 2017).

\subsubsection{Impedância Acústica}

A impedância acústica de um material pode ser definida como o produto da velocidade de propagação do som pela massa específica, o que determina características importantes sobre a quantidade de energia refletida e transmitida na inspeção entre dois meios.

Quando uma onda sonora se propaga em uma peça em que existe uma descontinuidade de material, isto é, existe uma interface entre dois materiais naquele equipamento, parte da energia sonora é refletida nesse ponto, enquanto a outra parte continua sua trajetória. A quantidade de energia sonora que será transmitida e refletida nas interfaces é dependente da impedância acústica dos dois materiais. No caso de impedâncias acústicas similares, a reflexão não ocorre. Quanto maior forem a diferença de impedância entre os dois materiais, maior será a reflexão na interface.

$\mathrm{Na}$ incidência oblíqua de uma onda ultrasônica, devem ser considerados os fenômenos de reflexão e de refração da onda incidente. Podem-se observar na Figura 7 as possibilidades de geração de ondas em uma interface a partir de uma onda longitudinal numa incidência oblíqua (Andreucci, 2017). 


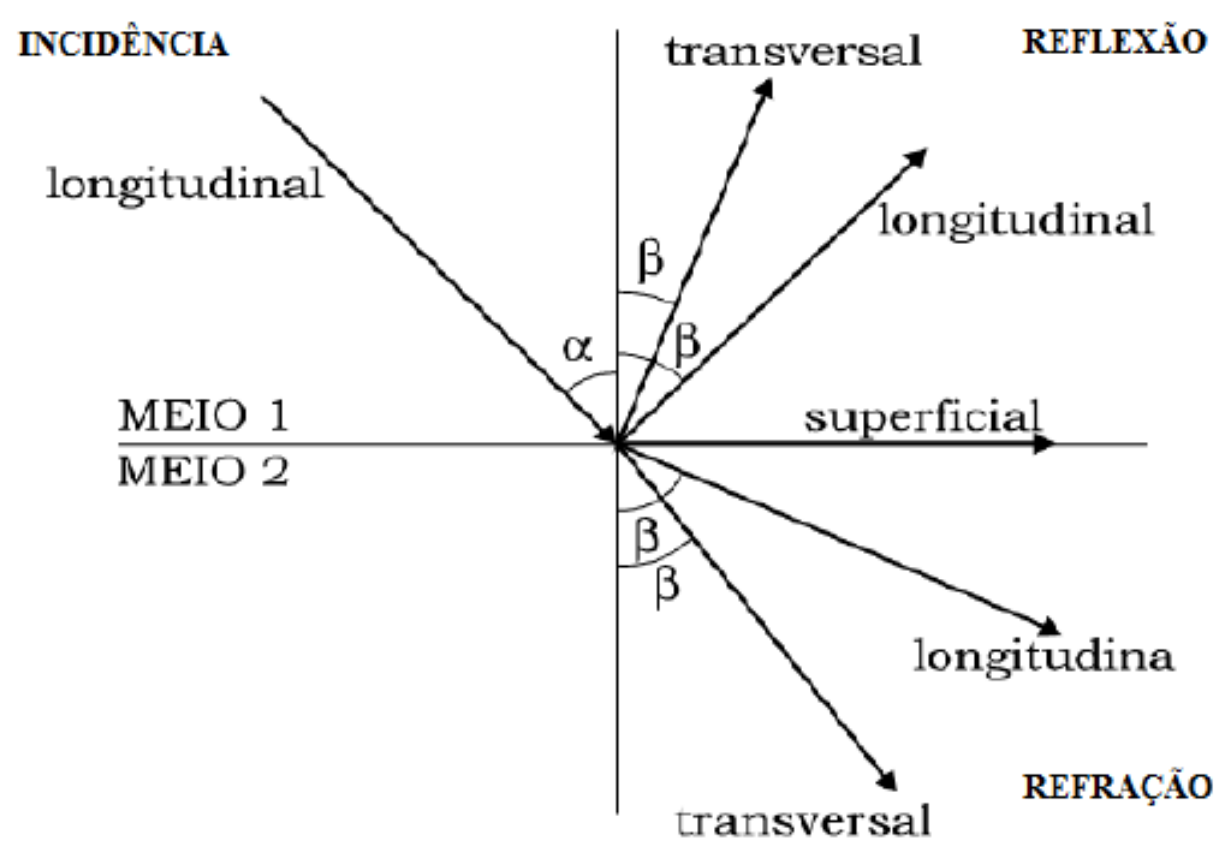

Figura 7 - Refração e reflexão da onda incidente.

\subsubsection{Geração de Ondas Ultrasônicas}

As ondas ultrasônicas são geradas por transdutores (Figura 8) nos quais cristais piezoelétricos, como quartzo, sulfato de lítio, titânio de bário, transformam uma aplicação de tensão mecânica em resposta de tensão elétrica e vice-e-versa. Estes cristais se deformam mecanicamente quando submetidos a uma diferença de potencial elétrico, assim como produz cargas elétricas quando o cristal sofre deformação mecânica. Para que seja alcançada uma onda ultrasônica, a frequência imposta no cristal deve ser da ordem de $50 \mathrm{kHz}$ a $100 \mathrm{kHz}$ para inspecionar materiais não metálicos, ao passo que, para materiais metálicos é utilizada, na inspeção, frequências entre 0,5 MHz a 10 MHz (Andreucci, 2017).

A transmisão e recepção do feixe podem ser feita pelo mesmo transdutor de cristais ou transdutores distintos, a depender do material do cristal e do tipo de técnica, por exemplo, o ToFD requer um receptor separado do transmissor, enquanto o PE necessita que o receptor seja junto do transmissor. 
a) Cristais com sinal em fase

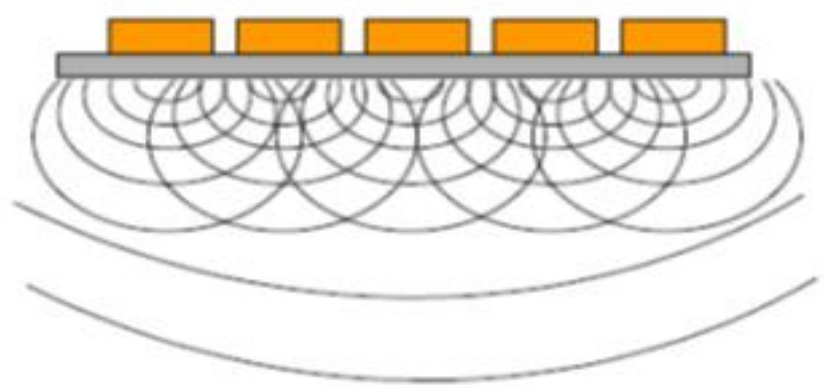

frente de onda resultante

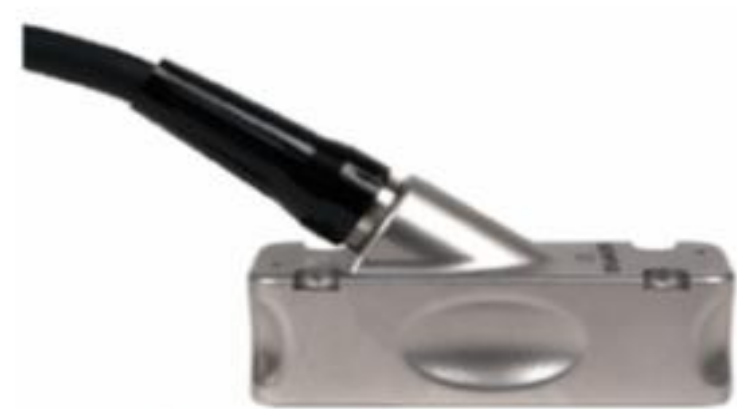

Transdutor Olympus com 60 elementos (cristais) , $5 \mathrm{MHz}$

b) Cristais com sinal defasado no tempo

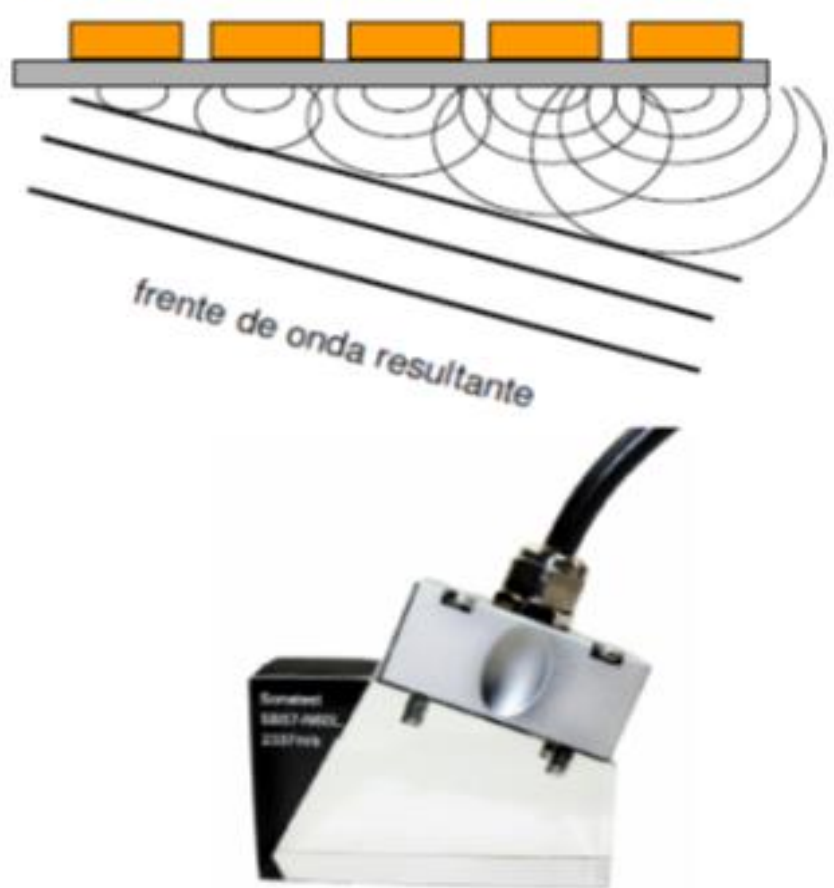

Transdutor com sapata intercambiável angular 60 graus 64 elementos, Sonatest

Figura 8 - Ilustração dos tipos de transdutors de ultrassom [Andreucci, 2017]. 


\subsection{Ultrassom Phased Array}

A técnica de Ultrassom Phased Array (UT-PA) vem adquirindo mais espaço e importância na indústria com o pasar dos anos. Devido a crescente necessidade de se obter uma maior precisão no dimensionamento de descontinuidades e propriedades mecânicas no menor espaço de tempo possivel.

Por diversas décadas a inspeção por radiografia industrial foi utilizada para a análise de dutos e tubulações industriais, porém a mesma apresenta limitações no dimensionamento de algumas descontinuidades, principalemte em casos onde o volume da descontinuidade seja muito pequeno em relação à espessura da seção inspecionada e da densidade do material, pois o feixe ultrasônico sofre grande atenuação antes e depois da reflexão no defeito, resultando em um sinal fraco. Alem disso, o ensaio por UT-PA demanda menores custos, maior velocidade e menor risco a saúde do trabalhador, sem contar uma maior precisão de resultados [Richter, 2007].

Com o desenvolvimento de hardwares e softwares, com circuitos e processadores mais rápidos, e desenvolvimento também de materiais novos materiais piezoeletricos, foi possível desenvolver uma tecnologia diferenciada em que funcionam em um mesmo transdutor uma serie de pequenos cristais, cada um deles ligado a circuitos independentes dos demais cristais, possibilitando em uma única varredura se inspecionar com diversos ângulos de refração distintos, uma vez que a mudança de ângulo é feita eletronicamente pelo controlador de UT-PA (Figura 9), fazendo, de maneira geral, que a velocidade seja menor e a identificação e dimensionamento de defeitos seja mais precisa.

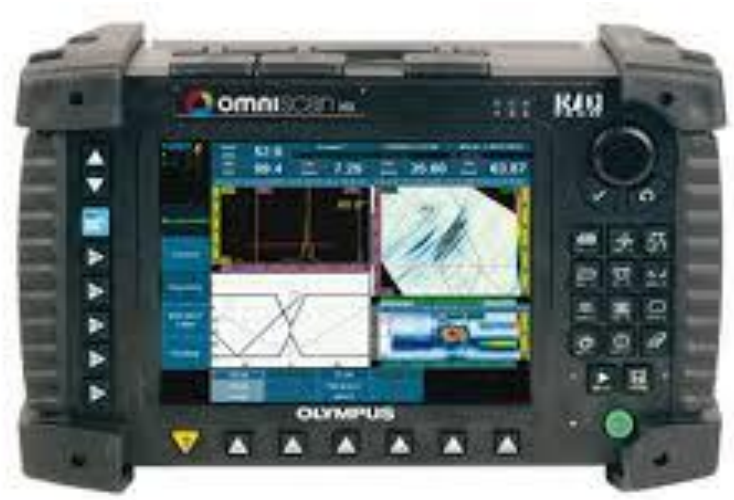

Figura 9 - Equipamento controlador OmniScan MX-2 para UT-PA. 


\subsubsection{Tipos de Representação Gráfica}

Existem diferentes vistas para a interpretação dos dados, que são adquiridos durante a realização da inspeção por UT-PA, as mesmas são: A-Scan, B-Scan, CScan e S-Scan. Cada um deles selecionado de acordo com o tipo de defeito que é esperado e o que se deseja dimensionar.

\subsubsection{A-scan}

Essa vista é muito utilizada durante as inspeções, pois mostra um ecograma onde na escala horizontal a posição dos picos determina a profundidade do agente de reflexão que deve ser medida empregando como parâmetro a posição da sonda durante a varredura e a escala vertical a altura dos picos indica a quantidade de energia que foi recebida pela sonda, quantificando a atenuação sônica do material e servindo como parâmetro para avaliação do defeito. A Figura 10 apresenta o resultado de uma inspeção com visualização em A-scan com detecção de uma trinca.

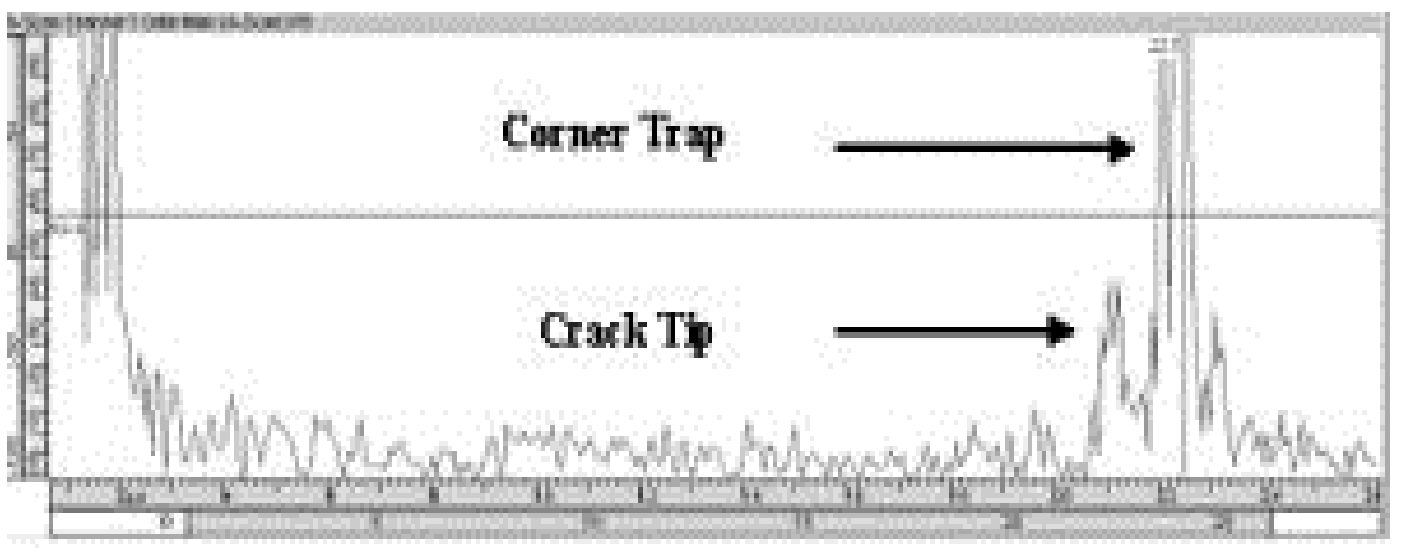

Figura 10 - Exemplo detecção de trinca por A-scan (Richter, 2007). 


\subsubsection{B-Scan}

A visualização em B-scan mostra a seção transversal à superfície inspecionada, de forma que um dos eixos equivale ao tempo decorrido e o outro retrata a posição do cabeçote ao longo da superfície de contato da peça inspecionada, tomando como parâmetro o início da coleta dos dados. As medidas das intensidades dos ecos de reflexão não podem ser realizadas diretamente como é realizado na vista A-scan. A Figura 11 ilustra a inspeção de um polimero com defeito interno com a técnica de visualização dos dados de inspeção em B-scan, sendo possivel localizar e dimensionar a descontinuidade no comprimento.

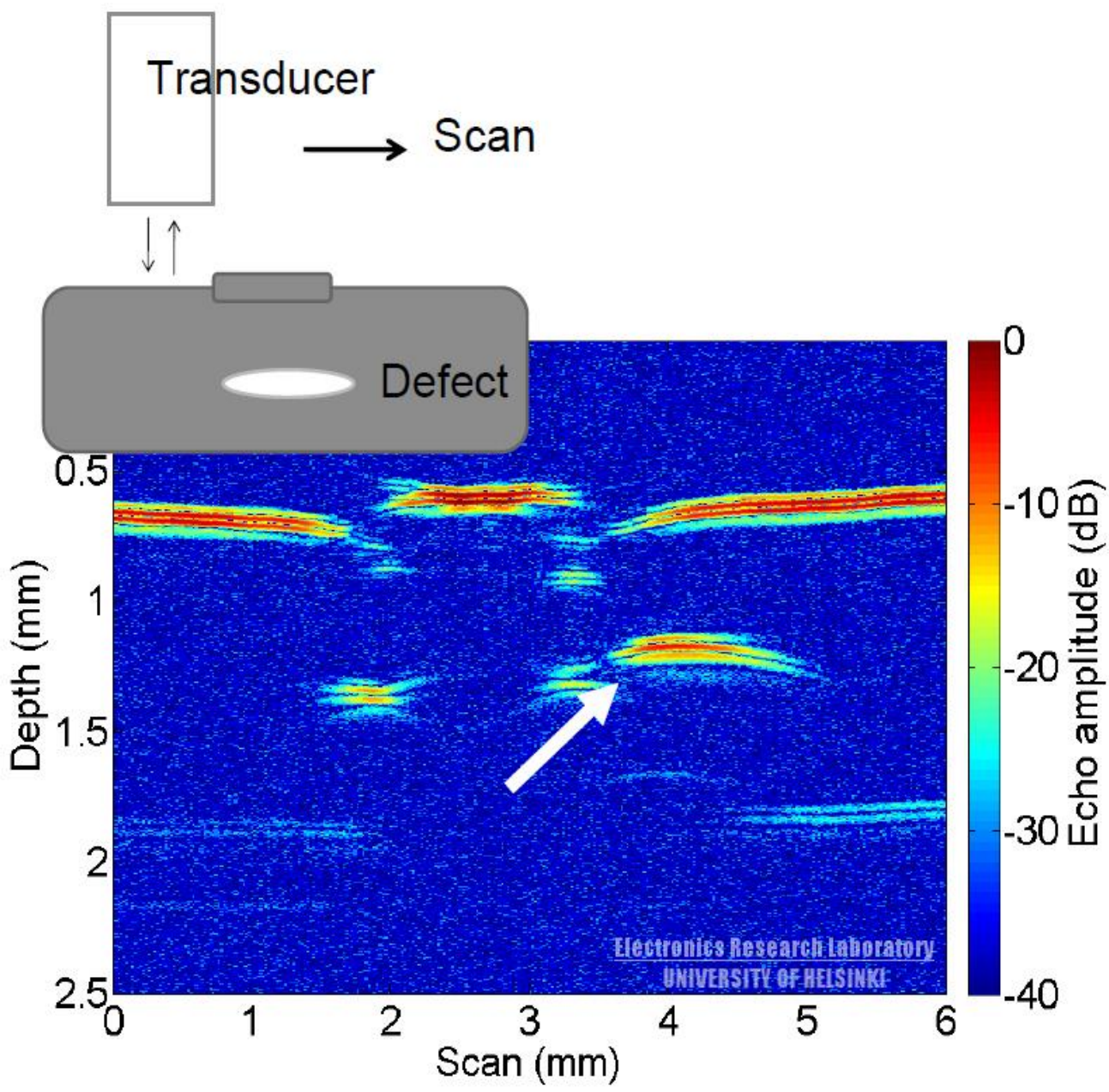

Figura 11 - Exemplo de um defeito em material polimerico por B-scan (Andreucci, 2017). 


\subsubsection{C-scan}

Neste modo de visualização os dados de inspeção são plotados graficamente exibindo uma vista em planta da superfície inspecionada, paralela a superficie de inspeção, indicando a posição e a largura da descontinuidade. Geralmente a profundidade não é dimensionada, mesmo que hoje existam sistemas que são capacitados para determinar de forma semi-quantitativa a profundidade das descontinuidades, por meio de superposição das imagens adquiridas. A Figura 12 exibe o resultado da inspeção de uma junta soldada com Phased Array com focalização na raiz da solda com a exposição dos dados em C-scan, é identificada a existência de descontinuidades caracterizadas como falta de fusão.

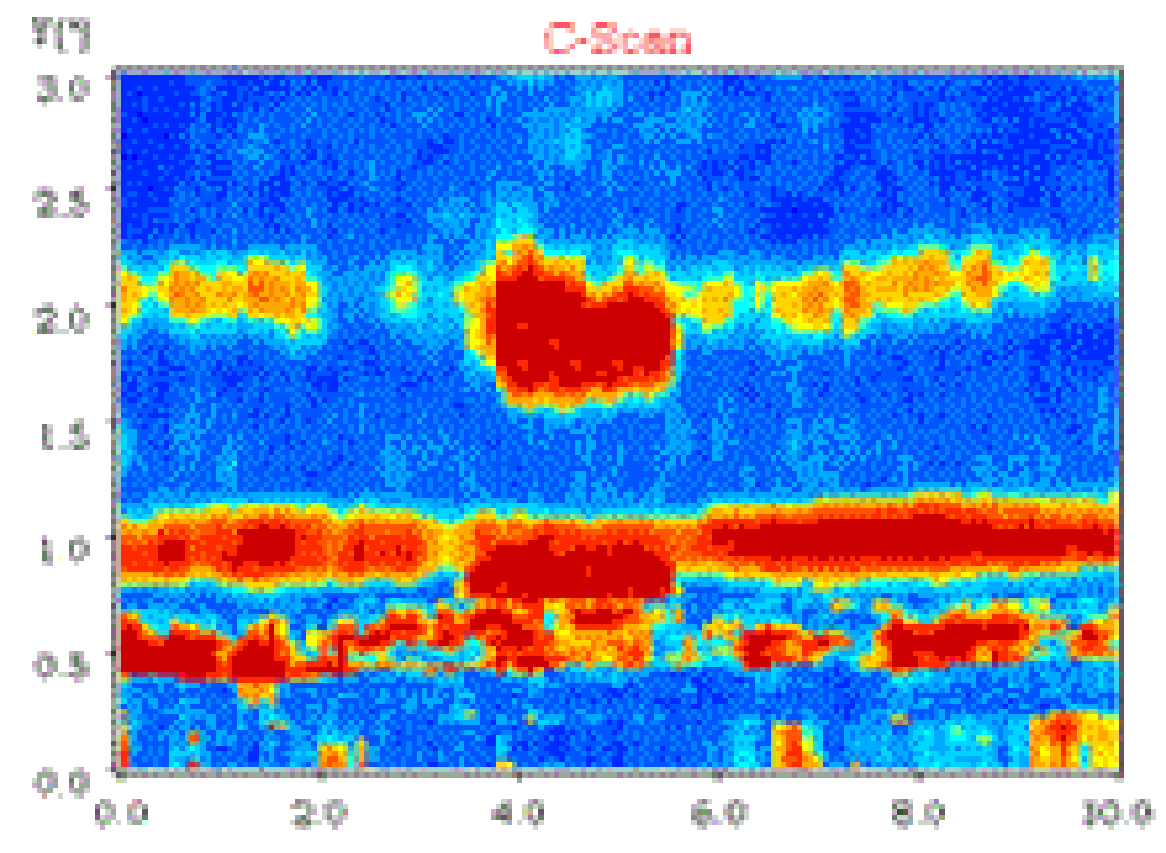

Figura 12 - Resultado da inspeção de uma solda por C-Scan (Andreucci, 2017).

\subsubsection{S-scan}

A exposição dos dados de inspeção em S-scan gera uma imagem de uma seção da espessura do material inspecionado e mostra possíveis descontinuidades presentes e detectadas pelas leis focais que foram produzidas para a inspeção. Os S-scans empregados na área industrial foram adaptados dos utilizados na área médica. As vistas em S-scan combinadas com os outros tipos de apresentação possibilitam determinar a morfologia do defeito encontrado, com a possibilidade de geração de uma imagem tridimensional caso haja mais desenvolvimento em 
software e hardware. A Figura 13, mostra o resultado de uma inspeção com Phased Array em S-scan com varredura setorial com os ângulos variando entre $42^{\circ}$ e $68^{\circ}$.

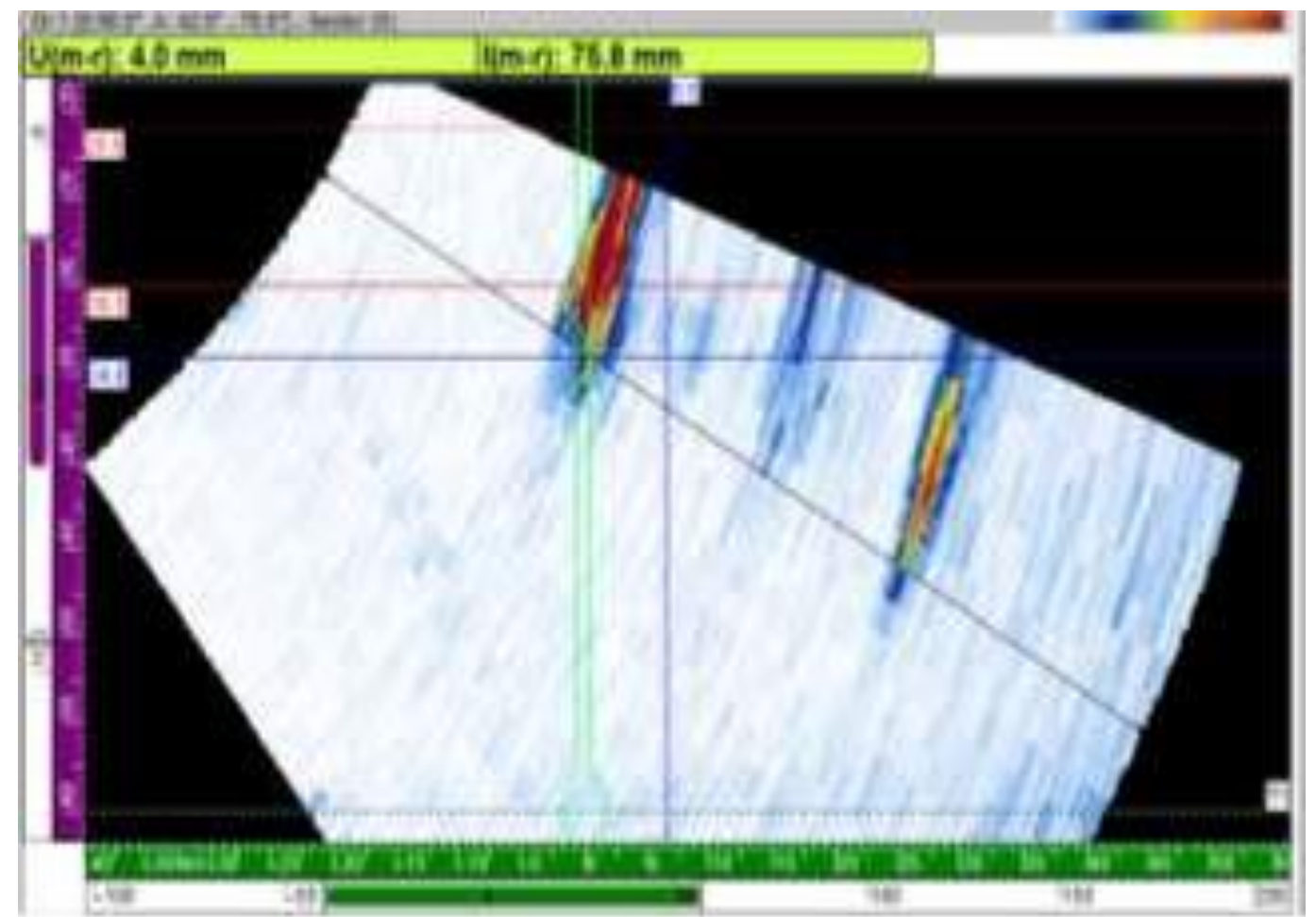

Figura 13 - Resultado em S-scan de um material com trinca (Andreucci, 2017).

\subsection{Técnicas de Inspeção por Ultrassom Phased Array}

Diversas técnicas podem ser empregadas nos testes por UT-PA dependendo de alguns fatores, como por exemplo, a natureza, dimensão e orientação das descontinuidades, condição da superfície, geometria do material à ser inspecionado e sua estrutura interna, isto é, com grãos grosseiros ou finos. As técnicas mais utilizadas nas inspeções feitas com Phased Array, para avaliação e dimensionamento de descontinuidades, são a pulso eco, TANDEM e o TOFD [Costa, 2014]. 


\subsubsection{Pulso-Eco}

Nessa técnica um mesmo transdutor é responsável tanto pela transmissão como pela recepção das ondas ultrassônicas que se propagam pelo material inspecionado. Estes pulsos que se propagam pelo material são refletidos pelas descontinuidades ou pela superfície oposta a superficie de contato entre a sonda e o material monitorado, que origina os sinais de reflexão recebidos pelo mesmo transdutor.

Para os transdutores Phased Array são adotadas defasagens no tempo dos sinais enviados (pulsos) e dos sinais recebidos (ecos) pelos seus elementos individuais. O tipo de onda, o ângulo de refração e a profundidade focal são parâmetros utilizados para determinar o tempo de atraso.

A Figura 14 apresenta desenho esquematico de uma inspenção de solda por PE com possíveis representações do sinal em A-scan, B-scan, C-scan, D-scan e Sscan.

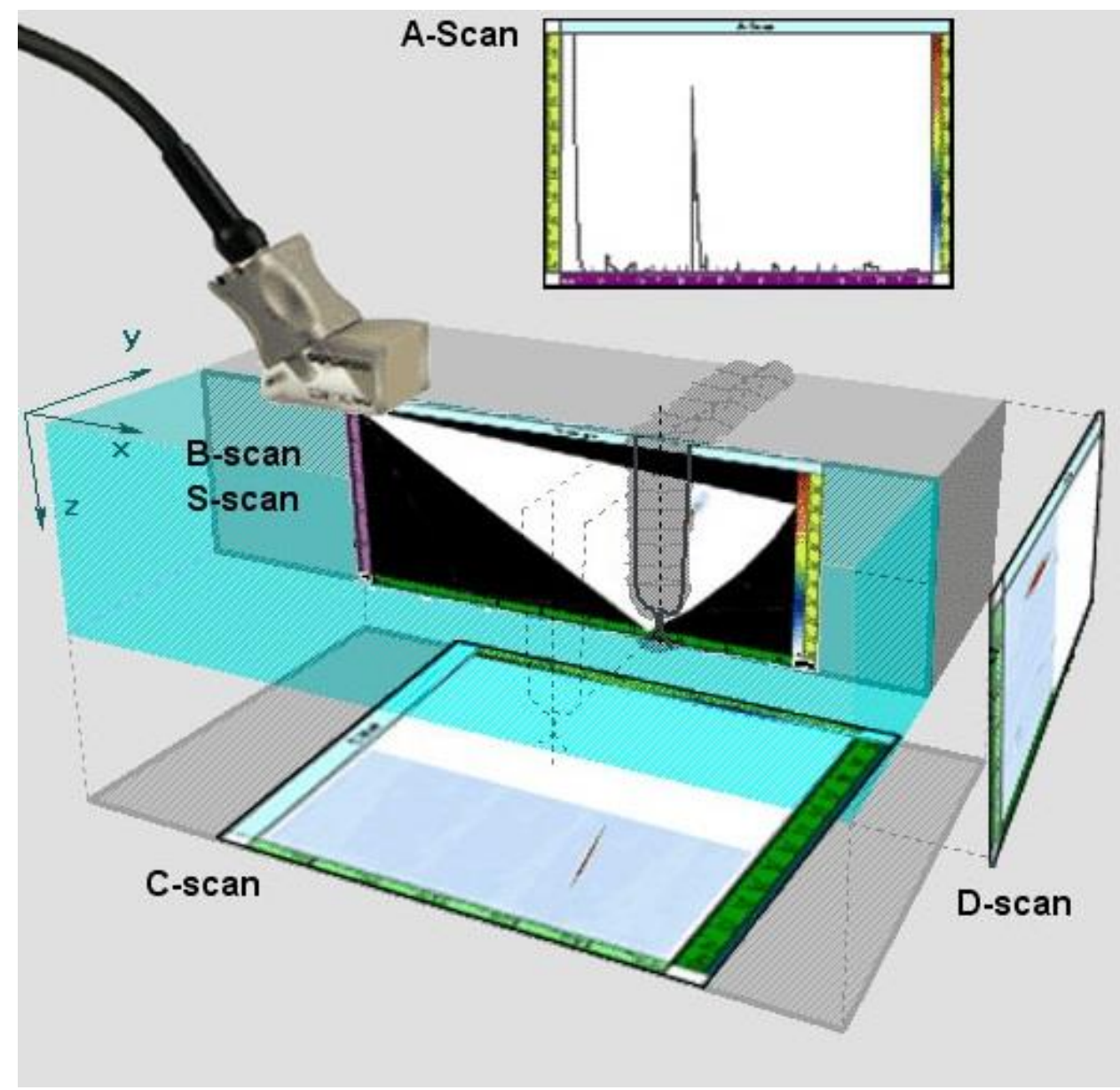

Figura 14 - Desenho das representações possíveis para UT-PA (Andreucci, 2017). 


\subsubsection{TANDEM}

Esta técnica é utilizada quando as inspeções são realizadas em peças de grandes espessuras onde há a dificuldade da onda ultrassônica refletir na descontinuidade e retornar ao transdutor, tendo como caracteristica a utilização de dois transdutores, um atuando como emissor e outro como receptor diferente da PE que um trandustor é responsável pelas duas funções.

Com essa técnica é possível realizar a detecção de descontinuidades que se encontram também na vertical, no entanto, não é adequada para realizar o dimensionamento de descontinuidades, já que apresentam limitações que vão requerer a utilização de outra técnica.

\subsubsection{Time of Flight Diffraction}

O TOFD (Time of Flight Diffraction) opera com um par de sondas ultrassônicas posicionadas na mesma superficie, porem em lados opostos de uma solda. Uma das sondas, o transmissor, emite um pulso ultrassônico que é captado pela sonda oposta, o receptor. Quando no material não contem descontinuidades, o sinal capturado pela sonda receptora é de duas ondas: uma que percorre a superfície e uma que se reflete na parede distante. Quando a descontinuidade está presente, há uma difração de baixa energia da onda ultrassônica pelas extremidades da descontinuidade. Usando o tempo de "vôo" medido do pulso, a profundidade do defeito pode ser calculada facilmente (Berke, 2017).

Para criar a imagem, o sinal analógico é digitalizado e quantificado em uma gama grande de tonalidades de cinza, ajustáveis entre o branco e o preto, apresentando uma vista em B-scan empilhada. O preto é a representação de um grande sinal positivo, enquanto o branco é a representação de um grande sinal negativo, sendo possível realizar uma visualização em D-scan, pois cada sinal de A-scan é substituído pela tonalidade de cinza associada com a amplitude do sinal, tornando possível que cada tela em A-scan que foi registrada na varredura, represente uma imagem bidimensional. A Figura 15 apresenta um desenho esquematico de uma chapa inspecionada com ToFD, com a representação de cada seção por A-scan e a combinação das seções em B-scan. Sendo possível notar a 
presença da onda superficial (LW), dos sinais de difração da descontinuidade existente na chapa (UT e LT) e do eco de fundo (BW).

As limitações desse tipo de técnica podem ser resumidas nos seguintes pontos: pequena relação sinal ruído, sensibilidade elevada para materiais com granulação grosseira, problemas de acoplamento em componentes de geometria complexa e o fato de a amplitude do sinal não estar diretamente relacionada com a dimensão da descontinuidade.

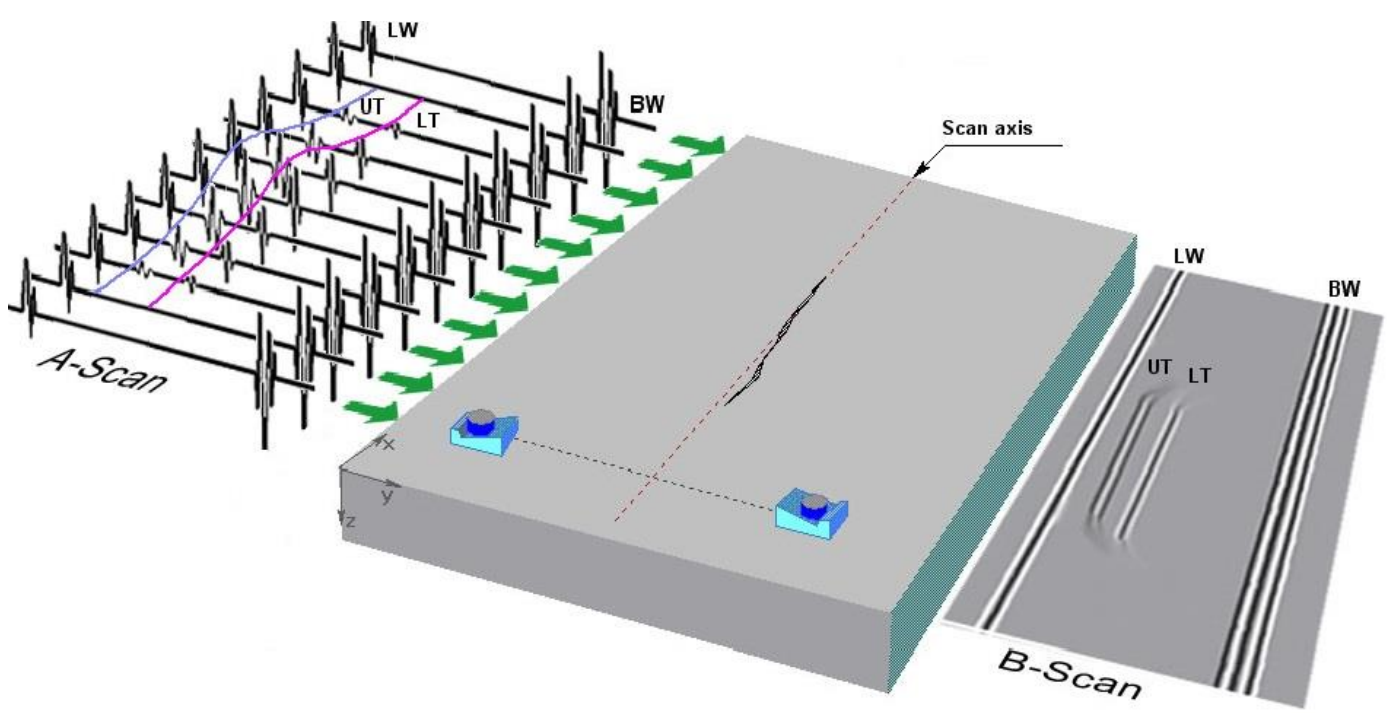

Figura 15 - Desenho esquematico da técnica ToFD e suas representações gráficas.

\subsection{Ensaio Radiográfico}

A radiografia é a técnica utilizada para a detecção de desigualdades de uma região de um determinado material que manifesta uma diferença na espessura ou na densidade quando comparada com uma região vizinha, isto é, um método capacitado para detectar com boa sensibilidade defeitos de material. Essa sensibilidade varia de acordo com o volume do defeito e o volume de material em volta do defeito, por exemplo, uma trinca pequena num tubo de aço carbono com grande espessura possivelmente não sera detectada, ao passo que um poro grande em um tubo de pequena espessura de matriz polimerica sera identificado e dimensionado com precisão (Andreucci, 2017). 


\subsubsection{Princípios Físicos}

O ensaio radiográfico emprega radiação ionizante, uma forma de onda eletromagnética, de alta energia e baixo comprimento de onda, como os raios $\mathrm{X}$ e Gama (Figura 16). Este tipo de radiação pode atravessar diversos tipos de materiais, como corpos opacos, metais, dentre outros, sendo posteriormente registrado em forma de filme radiográfico ou digital.

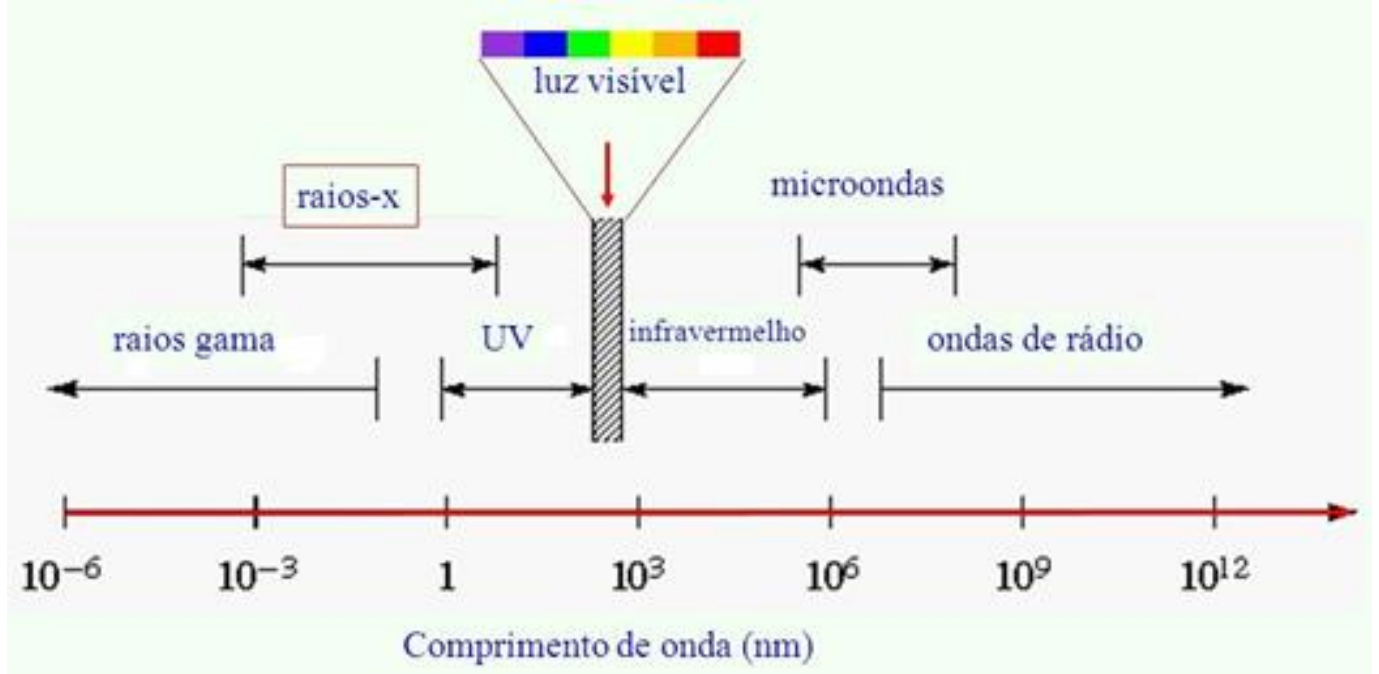

Figura 16 - Grafico do comprimento de ondas para diferentes tipos de ondas eletromagnéticas.

A radiografia é um método fundamentado na atenuação da radiação incidente sobre o corpo inspecionado. Essa atenuação ocorre em consequência da absorção do fóton de energia por elétrons do material e do espalhamento da onda na estrutura cristalina, sendo propriedade o coeficiente de atenuação linear do material estudado, que é proporcional à densidade e dependente da composição química.

A distinção na quantidade de radiação absorvida irá indicar a existência de uma falha interna ou defeito no material, como por exemplo, fratura em ossos ou defeito internos em componentes industriais. Desta forma existe uma diferenciação entre quantidade absorvida de radiação entre parte integra da peça e do local onde existe a descontinuidade, essa diferença de absorção produz, por consequência, uma diferenciação na imagem radiográfica resultante, onde a imagem apresenta tonalidade mais escura é devido à menor absorção de radiação pela peça, ou seja, uma maior quantidade de radiação atinge o filme, já a região mais clara da imagem ocorre o contrário, maior é a absorção de radiação pela peça e menor quantidade 
que atinge o filme neste local. Na Figura 17 podem ser visto dois defeitos em uma solda, uma trinca e um poro, que, por serem preenchidos por material não metálico, tem absorção de radiação menor do que a matriz metálica (Andreucci, 2017).

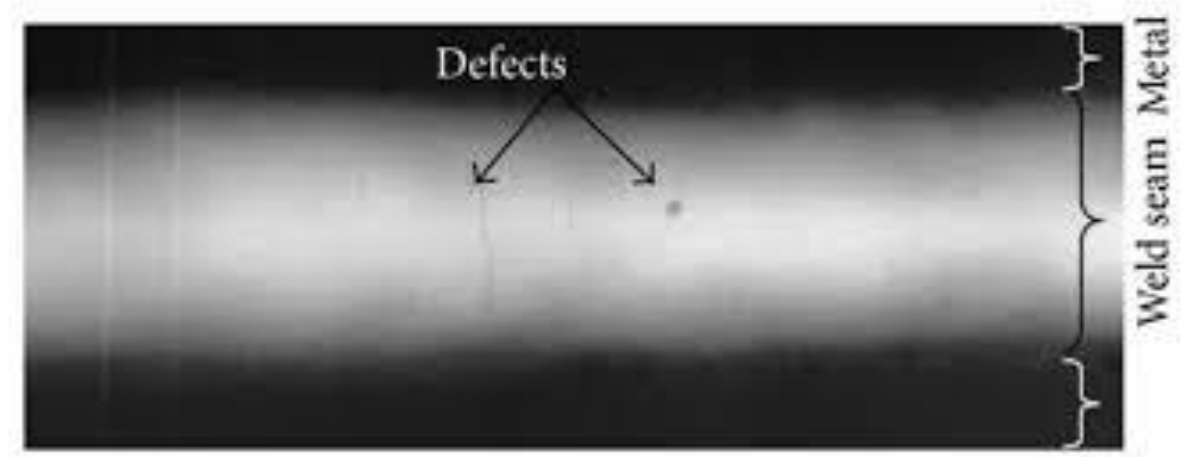

Figura 17 - Radiografia de uma solda com uma trinca e um poro.

Apesar da simplicidade do princípio em que é baseado o ensaio radiográfico, muitas variáveis podem induzir erros ou dificuldades na interpretação dos examinadores. Na realização do ensaio deve ser levado em consideração sempre a intensidade da radiação aplicada, o tipo e energia da radiação que será utilizada (X ou Gama), distância entre a peça e a fonte de radiação, assim como a distância que a peça deve ter do filme radiográfico. Esses parâmetros são sempre dependentes da sua composição química, do tamanho da peça e de que tipos de defeitos podem estar presentes.

\subsubsection{Fontes de Radiação}

$\mathrm{Na}$ indústria, dois tipos de radiação eletromagnética são empregados, com capacidade de penetração e forma de produção diferente, são eles os raios $\mathrm{X}$ e radiação Gama.

Os raios $\mathrm{X}$ empregados na indústria são produzidos por tubos de Coolidge, que são constituído de uma ampola com vácuo, um anodo e um catodo em seu interior. O catodo é composto de um filamento de tungstênio, no qual é aplicada uma corrente eletrica, que aquece o filamento por efeito joule e emitindo assim elétrons de maneira controlada. Estes elétrons são acelerados através do campo elétrico que e aplicado entre o catodo e o anodo. Essa energia cinética é transmitida ao o anodo pela colisão dos eletróns com os atomos e desta forma há uma interação 
de nível atômico, o que provoca a emissão de raios X que é emitido em forma de espectro contínuo graças as diferentes interações que os elétrons experimentam no anodo, desta forma são criados raios $\mathrm{X}$ com diferentes comprimentos de onda, já que interações atômicas são de diferentes umas das outras, que depende da diferença de potencial aplicada (Andreucci, 2017).

A radiação Gama decorre de isótopos radioativos criados por elementos naturais, colocados no núcleo do reator nuclear, submetidos a um bombardeamento de nêutrons. Quando o núcleo dos átomos destes elementos é atingido pelos nêutrons, estes elementos ficam instáveis e mudam a sua massa atômica, criando nesse momento os isótopos radioativos. No processo de restauração da estabilidade energética, partículas e energia são liberadas em forma de radiação Gama, que possui, normalmente, maior capacidade de penetração em relação ao raios $\mathrm{X}$ devido ao seu tamanho de comprimento de onda inferior (Figura 16). A capacidade de penetração tem uma importância fundamental na radiografia, uma vez que para analisar o interior de alguma peça é necessário que a radiação penetre completamente o material, pois o principio é de transmissão de radiação.

\subsubsection{Radiografia Digital}

A RD é uma variação da radiografia convencional pois se utiliza de poder computacional para processamento e tratamento da imagem gerada no ensaio radiográfico, através de filtros de imagem, o que culmina em uma imagem com qualidade superior à radiografia convencional. A Figura 18 apresenta uma comparação entre uma radiografia tradicional de uma curva tubulação soldada (à esquerda) e a curva inspecionada por radiografia digital (à direita). A diferença na qualidade de imagem é notavel, o que poderia permitir uma melhor visualização de um defeito nesta curva, caso existisse (Andreucci, 2017). 


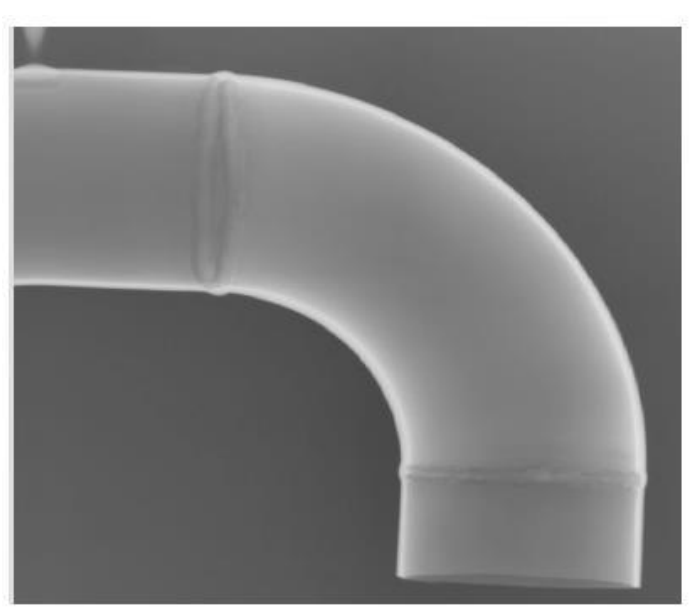

a)

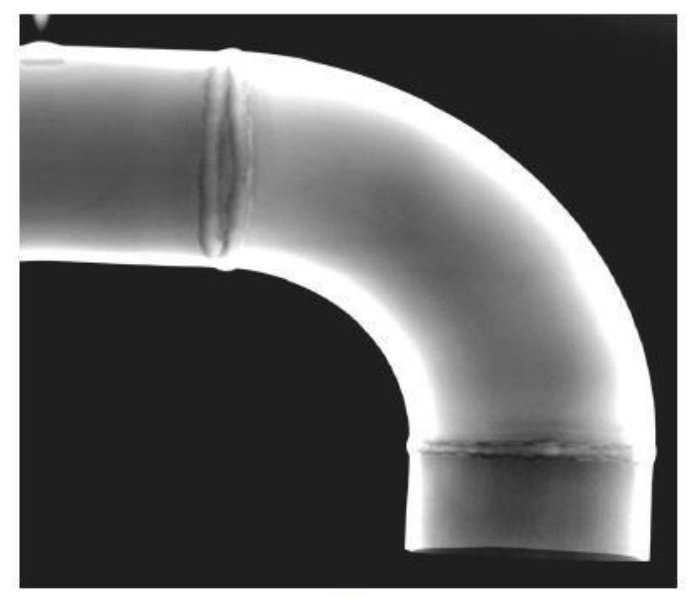

b)

Figura 18 - Radiografia a) tradicional e b) digital de uma curva soldada.

Esse processo de digitalização da radiografia pode ser realizado de três formas, pelo processo indireto, chamado de radiografia computadorizada, e processo direto, que é a radiografia digital. No processo indireto a radiação é absorvida pelo filme de absorção (placa de fósforo), o filme é então levado a um scanner que excita os elétrons de fósforo da placa com um feixe laser, emitindo assim luz, que é absorvida pelo detector do scanner, gerando assim uma imagem digital. O processo direto, por sua vez, utiliza um detector direto de radiação no lugar do placa de fósforo, transformando assim a radiação incidente em sinal elétrico, o que reduz perdas e melhora a eficiência do processo. Outra vantegem é o reaproveitamento do detector (Nilsson, 2014).

\subsubsection{Tomografia Computadorizada}

Podendo ser considerada uma evolução da RD, a Tomografia Computadorizada é a técnica que faz uma superposição de diversas imagens RD em diferentes ângulos de incidência com o material inspecionado, com o objetivo de gerar uma imagem em três dimensões do material. A aquisição da imagem é semelhante a da RD, sendo a diferença a quantidade de imagens e o software que faz o processamento dessas imagens (Nilsson, 2014). 


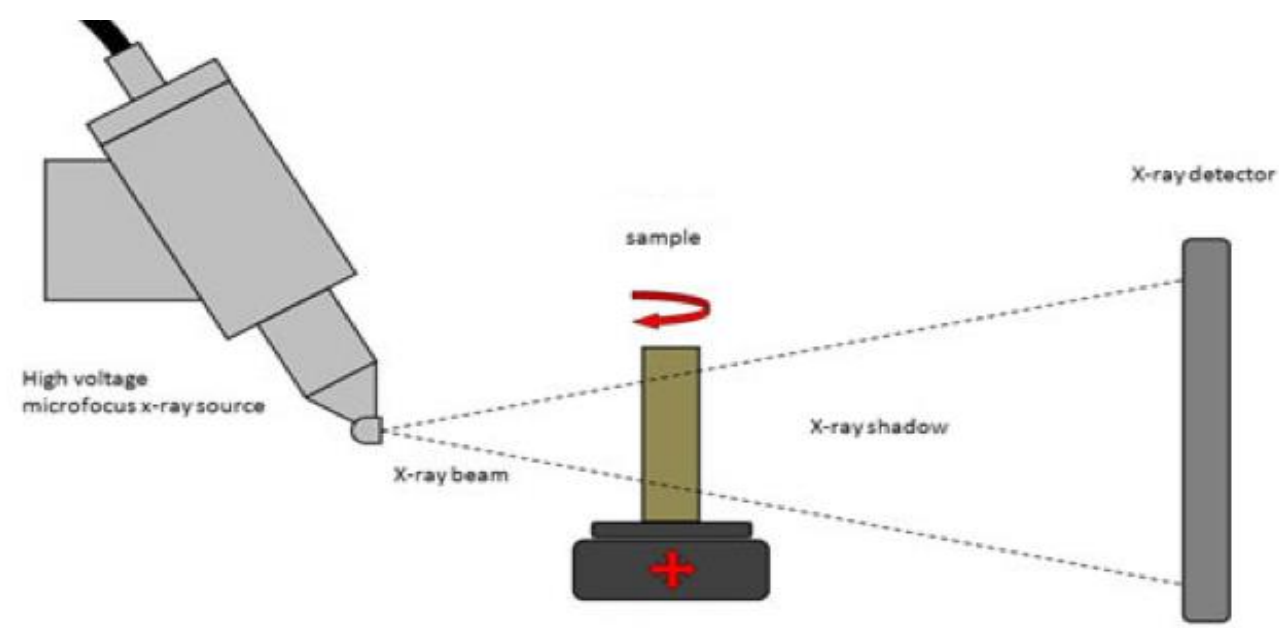

Figura 19 - Desenho esquemático da geração de imagens da TC.

A TC já vinha sendo utilizada na área médica com o objetivo de visualização interna de corpo humano a procura de alguma anomalia, como tumores. Mais recentemente passou a ser usada na indústria para visualização de diversos defeitos internos em materiais que necessitem de melhor resolução que a RD ou que tenham geometria muito complexa para serem usadas técnicas de ultrassom. Além disso, objetiva gerar uma imagem tridimensional do defeito, permitindo ver com perfeição sua geometria, o que permite, por exemplo, avaliar o CTOD de uma trinca no componente.

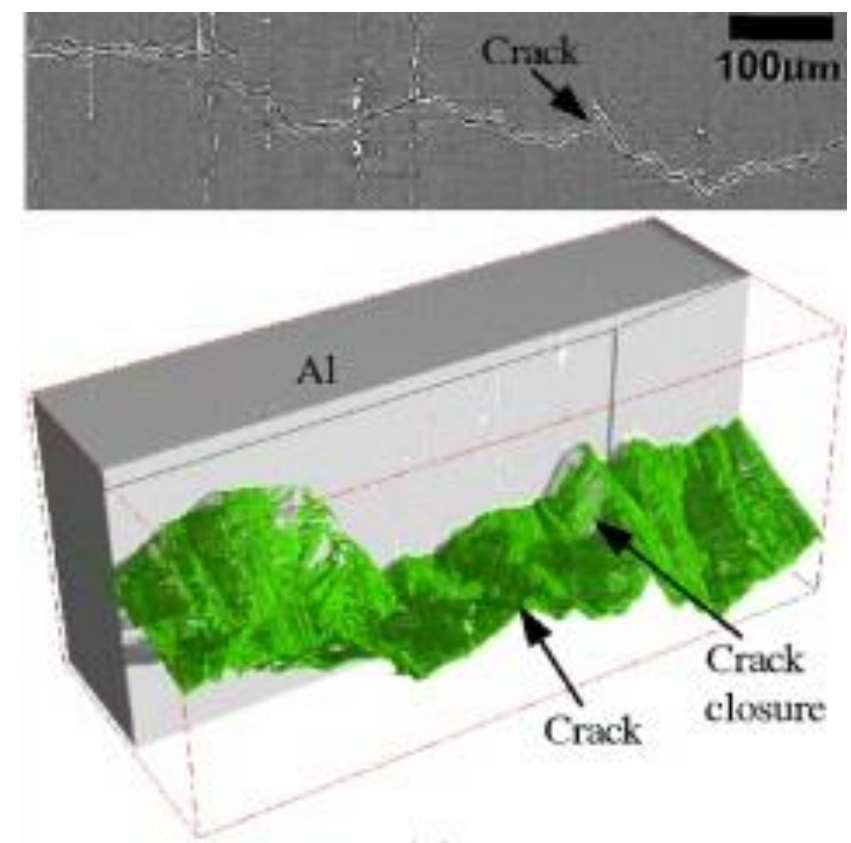

Figura 20 - Trinca em um bloco de alumínio (acima) e representação digital da trinca em 3D (Nilsson, 2014). 


\section{Metodologia}

\subsection{Material}

O material utilizado nesta pesquisa foi o aço estrutural 42CrMo4, de acordo com a norma DIN, cuja composição química encontra-se na Tabela 1. O material foi retirado de um eixo virabrequim de motor Diesel de usinas termoelétricas (Figura 21) que falhou por fadiga de baixo ciclo durante operação.

Tabela 1 - Composição química do aço DIN 42CrMo4 conforme recebido.

\begin{tabular}{|c|c|c|c|c|c|c|}
\hline $\mathbf{C ~ ( \% )}$ & Mn (\%) & Si (\%) & $\mathbf{C u}(\boldsymbol{\%})$ & $\mathbf{C r}(\boldsymbol{\%})$ & $\mathbf{V}(\boldsymbol{\%})$ & Mo (\%) \\
\hline 0,38 & 0,85 & 0,27 & 0,18 & 0,97 & 0,01 & 0,2 \\
\hline
\end{tabular}

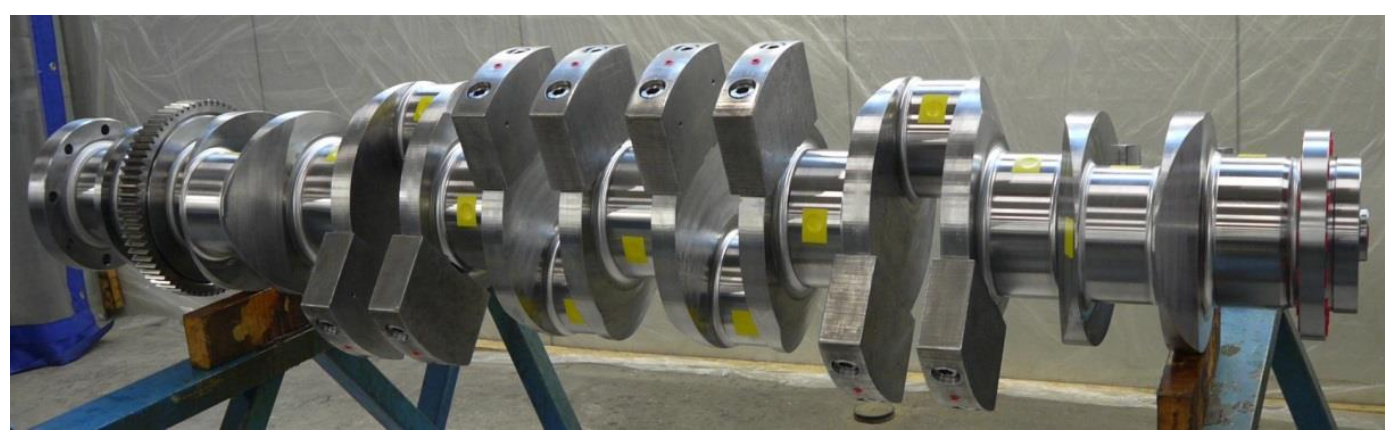

Figura 21 - Eixo virabrequim de motor Diesel de termoelétrica.

\subsection{Corpos de Prova}

Os corpos de prova foram projetados, em um primeiro momento, de acordo com as normas ASTM E1820 e ASTM E1290, que são normas para ensaio de CTOD, devido à similaridade com a geometria proposta (Figura 22) ao trabalho anterior para uma melhor inspeção por UT-PA, similar ao corpo SE(B) das normas da ASTM. Um protótipo foi então fabricado, para que a geometria fosse validada pela inspeção por UT-PA. Após a inspeção do protótipo de corpo de prova, foi constatado que o entalhe gerava muito ruído, sendo proposta uma geometria 
diferente, tendo como característica um entalhe de menor dimensão. Para esse proposito, a norma ISO 15653 demonstra uma geometria ideal frente à geometria proposta, pois o que difere da geometria das normas ASTM E1820 e ASTM E1290 é a profundidade do entalhe.

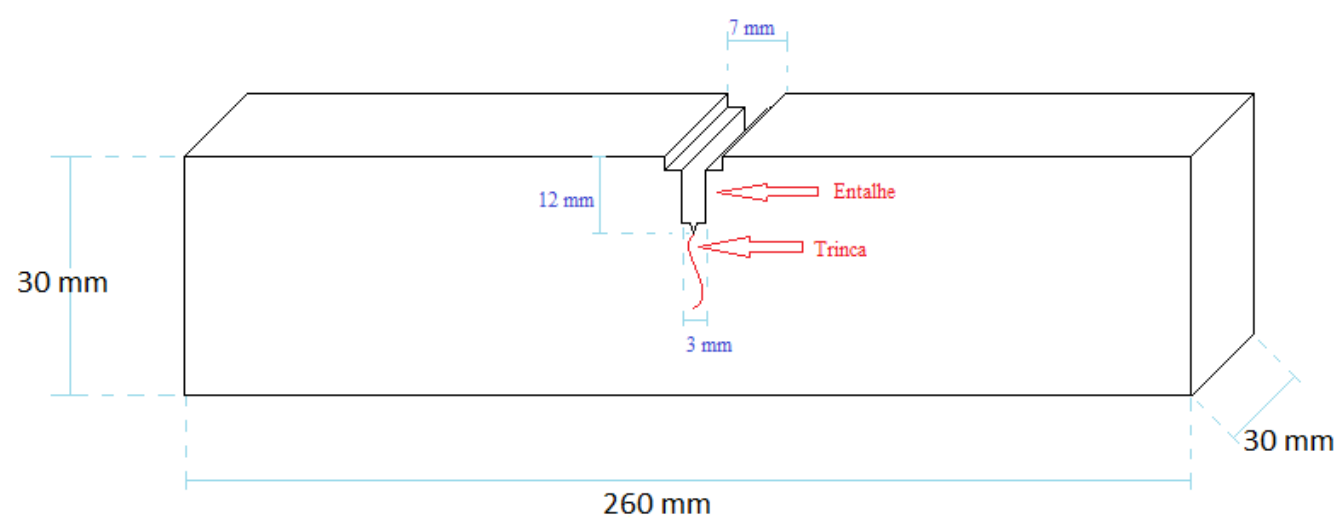

Figura 22 - Geometria de corpo de prova adaptado à proposta pelo trabalho anterior.

Os corpos de prova seguiram então o desenho proposto, sendo fabricado um corpo de prova com entalhe de profundidade de $10,0 \mathrm{~mm}$ e três com entalhes de profundidade de 3,0 mm (Figura 23), de acordo com o padrão SE(B) quadrado, de seção 30x30 mm e comprimento de $260 \mathrm{~mm}$. Essa quantidade foi devido a pouca disponibilidade de material do virabrequim fraturado.
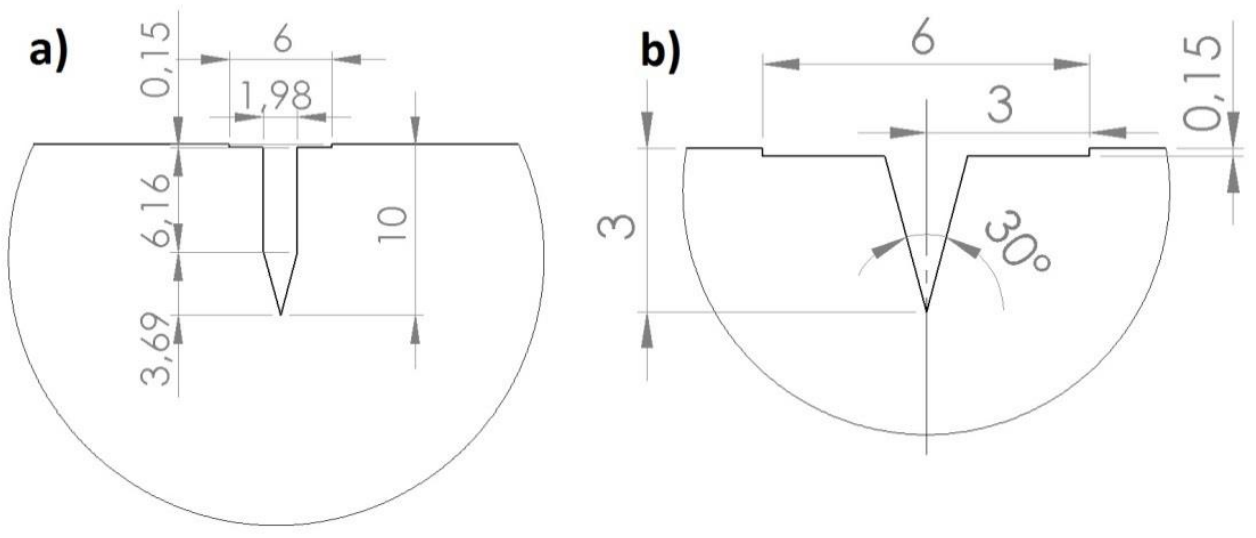

Figura 23 - Detalhe de fabricação para a) ASTM E1820; e b) ISO 15653 (dimensões em milímetros).

Os corpos de prova foram denominados de CP01, CP02, CP03 e CP04 para fins de identificação, não seguindo ordenação específica. 


\subsection{Nucleação e Propagação de Trincas}

Conforme citado no item 3.2, os corpos de prova foram projetados de acordo com as normas ASTM E1820, ASTM E1290 e ISO 15653, o mesmo pode ser dito para a iniciação de trincas de fadiga nos corpos de prova, denominado de pré-trinca de fadiga nas normas. Portanto, os corpos de prova foram submetidos a um carregamento cíclico em flexão (Figura 24). Como o espaçamento dos apoios informado é o mínimo admissível, foi utilizado um espaçamento maior, com valor de $230 \mathrm{~mm}$ entre apoios e carga centralizada, calculada pela formula:

$$
P_{a d m}=\frac{0,5 B b_{0}^{2} \sigma_{y}}{S}
$$

Essa é a carga máxima admissível $\left(P_{a d m}\right)$, sendo o procedimento da norma de iniciar o processo de trincamento com uma carga máxima $\left(P_{\max }\right)$ equivalente á $60 \%$ da $P_{a d m}$. É também estabelecido que a carga mínima $\left(P_{\min }\right)$ seja equivalente a $10 \%$ da carga máxima, sendo então a razão de carga $(\mathrm{R})$ dos ensaios de iniciação de trinca igual a 0,1. A Tabela 2 apresenta os valores de carga máxima admissível para os diferentes corpos de prova, tanto para a carga inicial $\left(P_{0}\right)$, somente com entalhe ( $\left.a_{\text {entalhe }}\right)$, como para carga $\left(P_{i}\right)$ relativa a diferentes tamanhos de trinca $\left(a_{0}=a_{\text {entalhe }}\right.$ $\left.+a_{\text {fadiga }}\right)$. Os tamanhos de trinca foram escolhidos a fim de aumentar o espectro que pode ser detectado pelos ensaios.

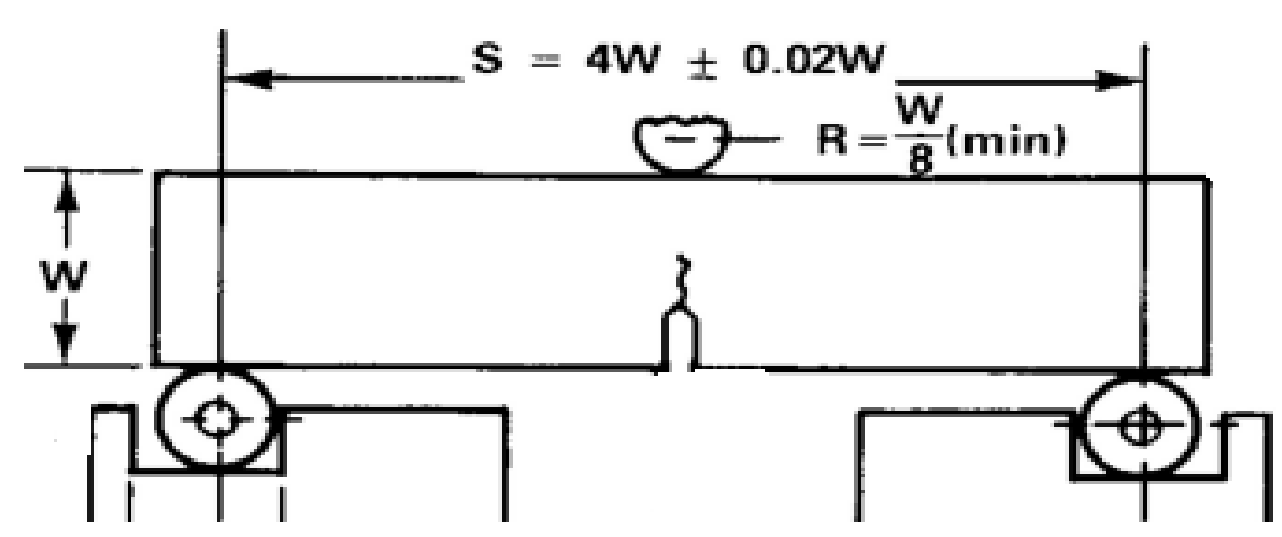

Figura 24 - Desenho esquemático do ensaio por flexão em três pontos (retirado da norma ASTM E1290 versão 2008). 
Tabela 2 - Comprimento de trinca inicial pretendido: $a_{0}=a_{\text {entalhe }}+a_{\text {fadiga }}$ e respectivas cargas

\begin{tabular}{|c|c|c|c|c|c|c|}
\hline $\begin{array}{c}\text { Identificação dos } \\
\text { corpos de prova }\end{array}$ & $\begin{array}{c}\boldsymbol{a}_{\text {entalhe }} \\
(\mathbf{m m})\end{array}$ & $\begin{array}{c}\boldsymbol{a}_{\text {fadiga }} \\
(\mathbf{m m})\end{array}$ & $\begin{array}{c}\boldsymbol{a}_{\mathbf{0}} \\
(\mathbf{m m})\end{array}$ & $\begin{array}{c}\boldsymbol{b}_{\mathbf{0}} \\
(\mathbf{m m})\end{array}$ & $\begin{array}{c}\boldsymbol{P}_{\mathbf{0}} \\
(\mathbf{k N})\end{array}$ & $\begin{array}{c}\boldsymbol{P}_{\boldsymbol{i}} \\
(\mathbf{k N})\end{array}$ \\
\hline CP01 & 3,0 & 3,0 & 6,0 & 24,0 & 33,3 & 26,3 \\
\hline CP02 & 3,0 & 5,0 & 8,0 & 22,0 & 33,3 & 22,1 \\
\hline CP03 & 3,0 & 4,0 & 7,0 & 23,0 & 33,3 & 24,2 \\
\hline CP04 & 10,0 & 6,0 & 16,0 & 14,0 & 18,3 & 9,0 \\
\hline
\end{tabular}

Os corpos de prova $\mathrm{SE}(\mathrm{B})$ foram submetidos à fadiga em flexão de três pontos com as carga apresentadas na Tabela 2 nas máquinas MTS 810-250kN e MTS 810$500 \mathrm{kN}$, com capacidade de 250 e $500 \mathrm{kN}$ respectivamente (Figura 25).

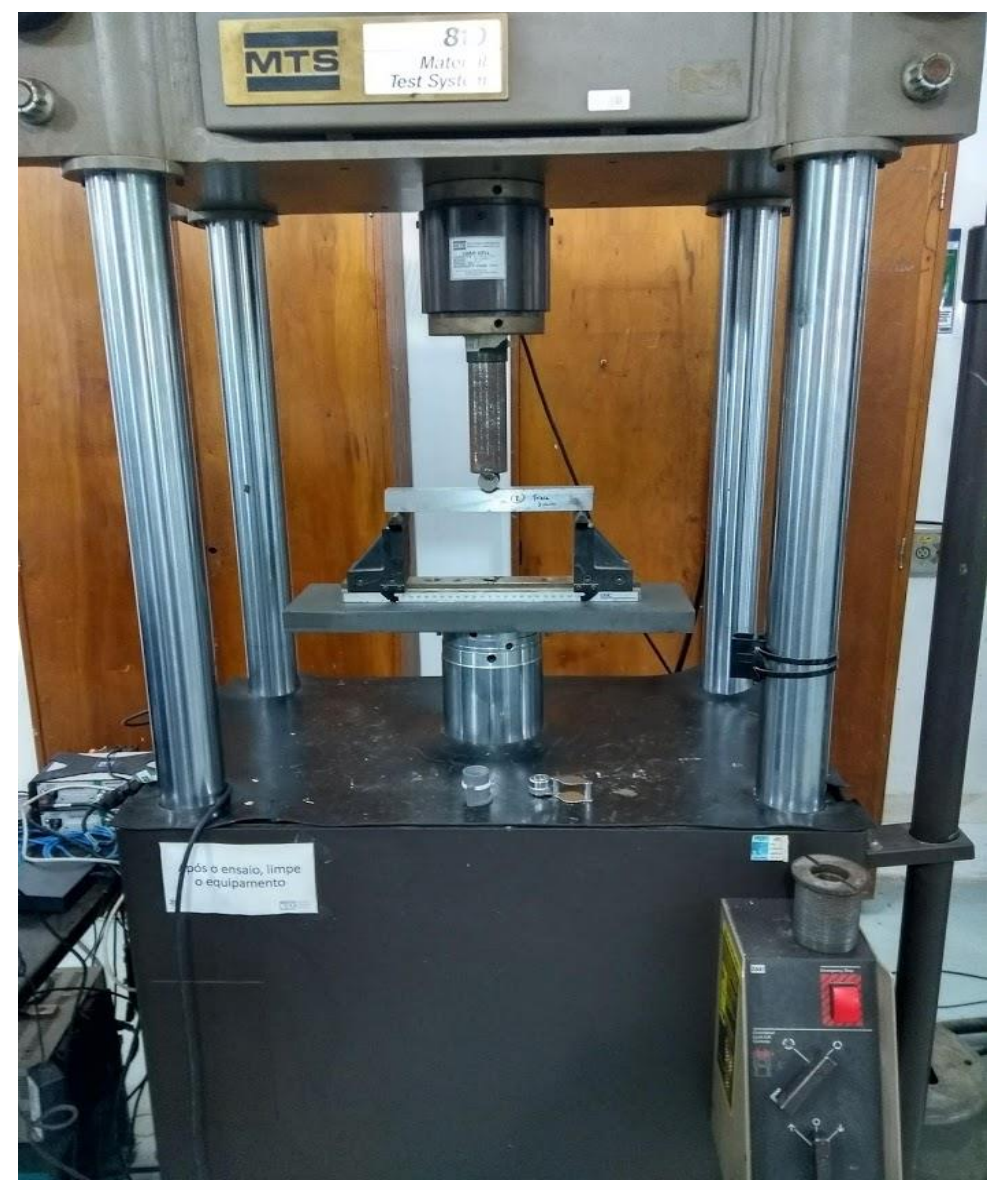

Figura 25 - Visão geral da Máquina MTS 810-500 kN com corpo de prova CP01 posicionado para ensaio de fadiga por flexão. 


\subsection{Técnicas de Ensaios Não-Destrutivos}

\subsubsection{Ultrassom Phased Array}

A inspeção por UT-PA foi realizada por dois métodos, Pulso-Eco e TfOD, com o intuito de comparação dos resultados dos mesmos. O equipamento de ultrassom utilizado em ambos os métodos foi o modelo Omniscan MX2, de 32/128 canais, versão MXU 4.4 R2, e o software foi o Tomoview, na versão 2.10 ver. R22, ambos de fabricação da Olympus NDT (Figura 26).

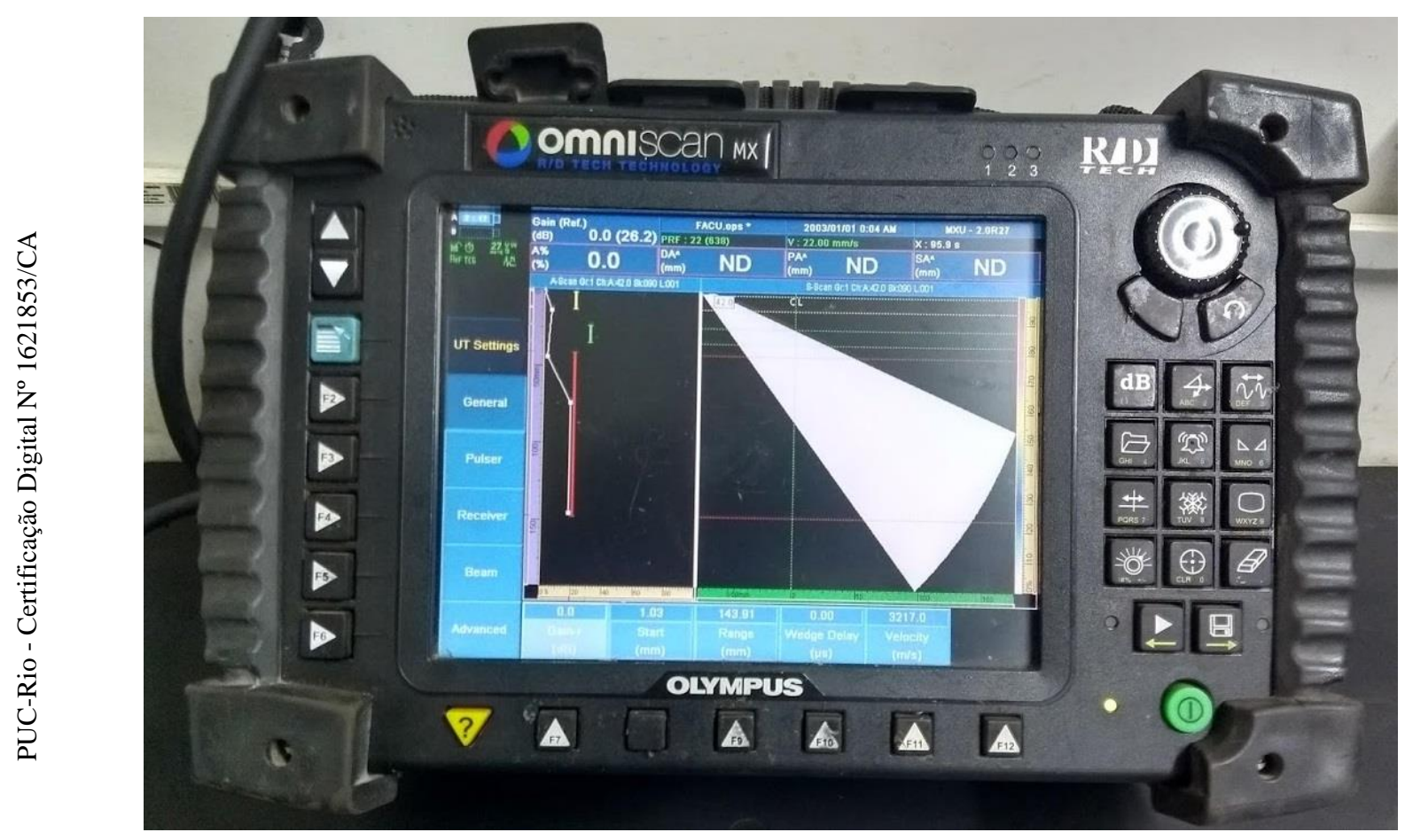

Figura 26 - Foto do equipamento Omniscan MX2 utilizado com o software tomoview utilizado.

Para verificar se a posição dos cabeçotes em relação a trinca/entalhe produz interferência nas medições realizadas, foram realizadas inspeções na superfície que contem a raiz do entalhe e na superfície oposta a ela, em ambos os métodos. No caso do Pulse-Eco houve, também, a variação do lado da superfície que foi realizado a inspeção. Então ficou definida a nomenclatura das superfícies e lados conforme a (Figura 27). 


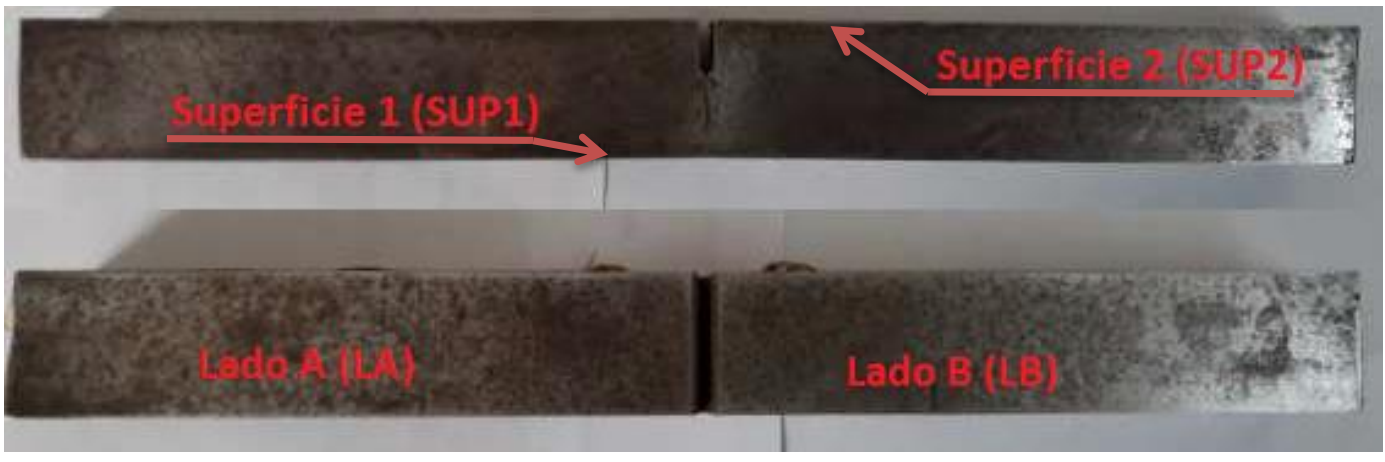

Figura 27 - Foto do corpo de prova com esquema da nomenclatura.

\subsubsection{Pulso-Eco}

Essa técnica foi utilizada por contato direto, utilizando equipamento da Olympus NDT, sendo o cabeçote o modelo 5L64-A12, de cinco MHz de frequência e 64 elementos e a sapata modelo SA12-N55S com ângulo de $55^{\circ}$. A inspeção foi realizada conforme é usual para inspeção de juntas soldadas, desta forma, o plano de varredura foi elaborado simulando uma situação cotidiana de ensaio de solda, com ângulo de feixe entre $42^{\circ}$ e $70^{\circ}$. A Figura 28 apresenta um desenho esquematico da inspeção em questão para uma junta soldada.

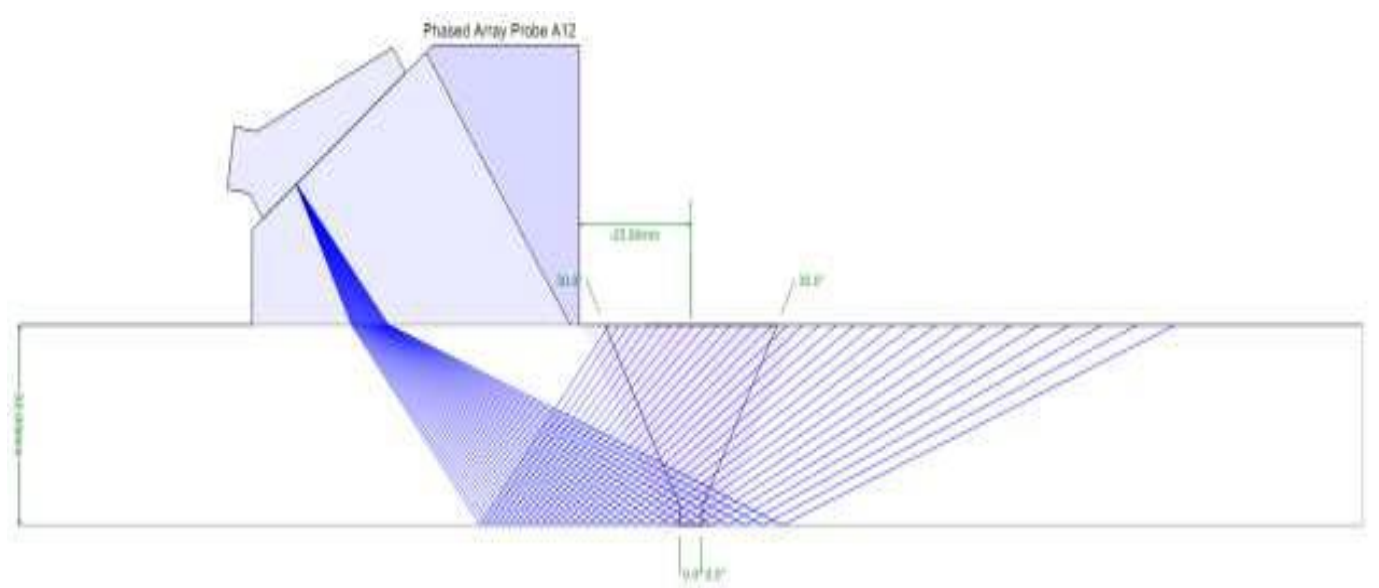

Figura 28 - Desenho esquemático da inspeção pelo método de PE. 


\subsubsection{Time of Flight Diffraction}

Assim como o método Pulse-Eco, a inspeção foi realizada seguindo orientações para inspeção de juntas soldadas, sendo apresentado o desenho esquemático na Figura 29. Diferentemente da inspeção por Pulse-Eco, a inspeção por ToFD não tem como ser realizada variando o lado da superfice de inspeção devido a utilização de um cabeçote emissor e um cabeçote receptor. $\mathrm{O}$ cabeçote utilizado foi o modelo C543 de $5 \mathrm{MHz}$ de frequência e a sapata omdelo ST1-60LIHC com $60^{\circ}$ de ângulo, ambos de fabrição da Olympus NDT.

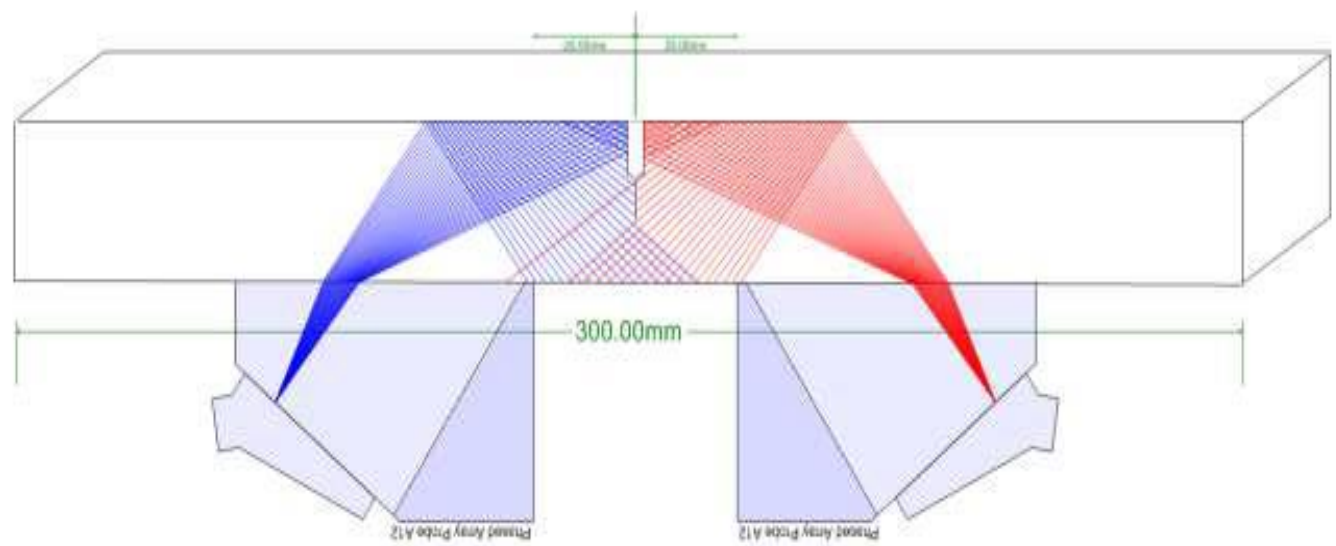

Figura 29 - Desenho esquemático da inspeção pelo método ToFD.

\subsection{Radiografia Digital}

O ensaio por Radiografia Digital (RD) aconteceu pela técnica de PS-VS com uma posição. Os equipamentos utilizados foram um tubo de raios $\mathrm{X}$ modelo ERESCO 300 MF4-R, com intervalo de tensão entre 10-300 kV, e um flat panel modelo DXR250CW, com dimensão ativa de 200 x 200 mm, ambos de fabricação da GE (General Eletric). O intuito da RD foi de mensurar o valor da trinca pela lateral do corpo de prova e comparar com o valor lateral da trinca de fadiga, para tal, o ensaio foi realizado de acordo com o esquemático da Figura 30. 


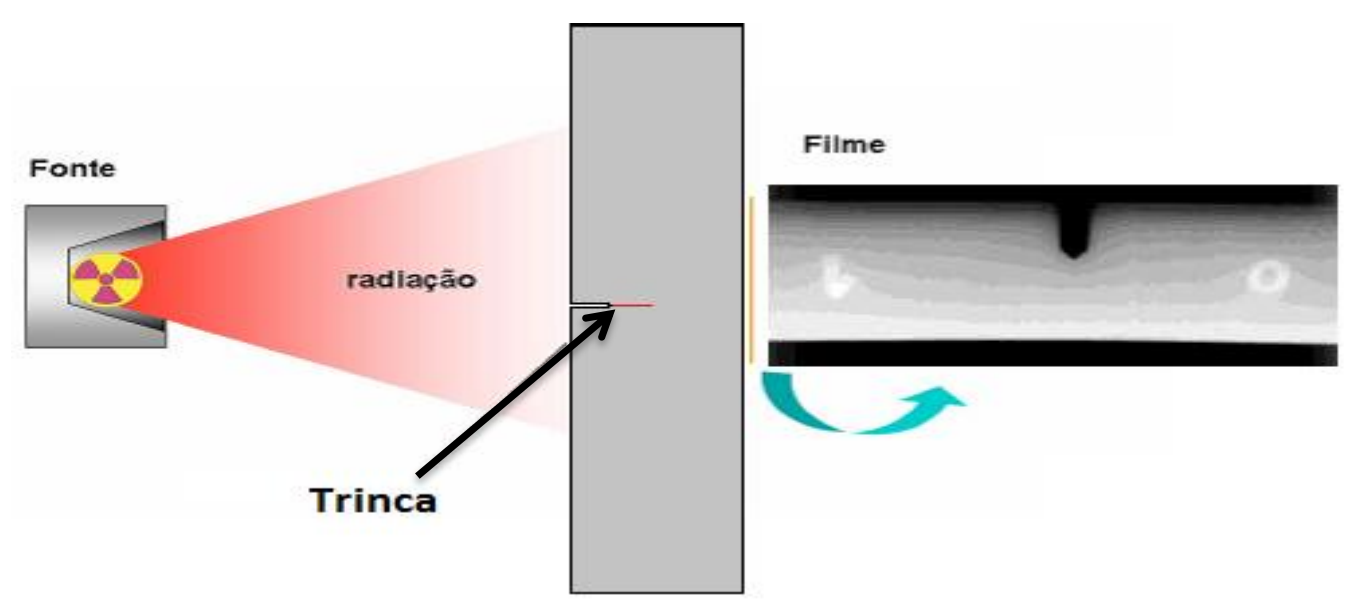

Figura 30 - Desenho esquemático do ensaio por RD.

Após tratamento da imagem por filtros, se obteve uma imagem com melhor contraste, o que permitiu mensurar o tamanho lateral da trinca. Os parametros do ensaio foram, $280 \mathrm{kV}$ de tensão, $2 \mathrm{~mA}$ de corrente, 4 segundos de exposição e distancia da fonte de $1000 \mathrm{~mm}$.

\subsection{Tomografia Computadorizada}

A Tomografia Computadorizada (TC) é resultado da interpolação de diversas projeções geradas pela incidência de raios X na peça, ou seja, é uma combinação de um serie de projeções radiográficas realizadas, o que permite ver o defeito como um todo, pois a TC gera uma imagem 3D do mesmo em alta resolução. A aquisição das imagens foram feitas utilizando o sistema de TC modelo Phoenix VTomex (Figura 31), fabricado pela GE, o programa para aquisição de dados foi o Datosx 2 aquisition, versão 2.5.0, e o programa para reconstrução das imagens foi o Datosx 2 reconstruction, versão 2.5.0 TRM. 


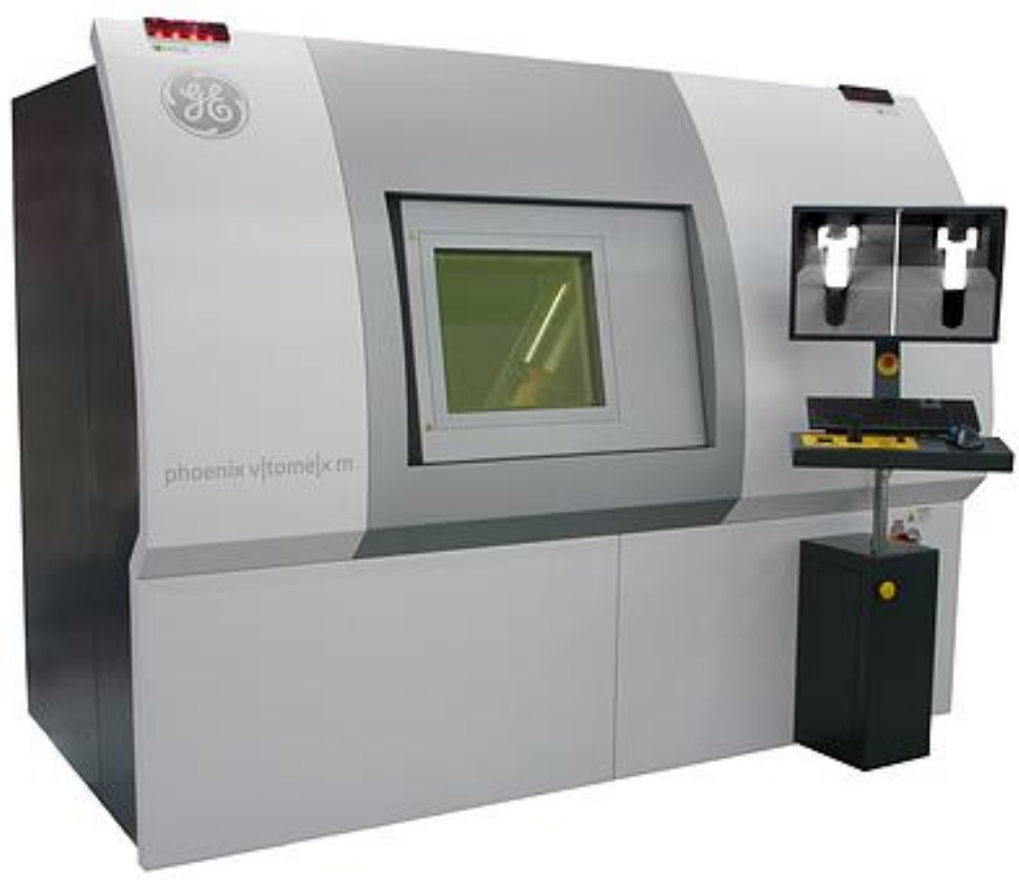

Figura 31 - Sistema de microCT Phoenix VTomex, da fabricante GE.

Os parâmetros usados para aquisição das imagens foram: tensão de $260 \mathrm{kV}$; Corrente de $270 \mu \mathrm{A}$, filtro de $0,5 \mathrm{~mm}$ de aço, tempo de aquisição de 250 ms/projeção; integração de 7 frames; e 720 projeções. Sendo, posteriormente, as imagens tratadas pelo software para aumentar o contraste da imagem.

\section{x-ray source sample array detector}

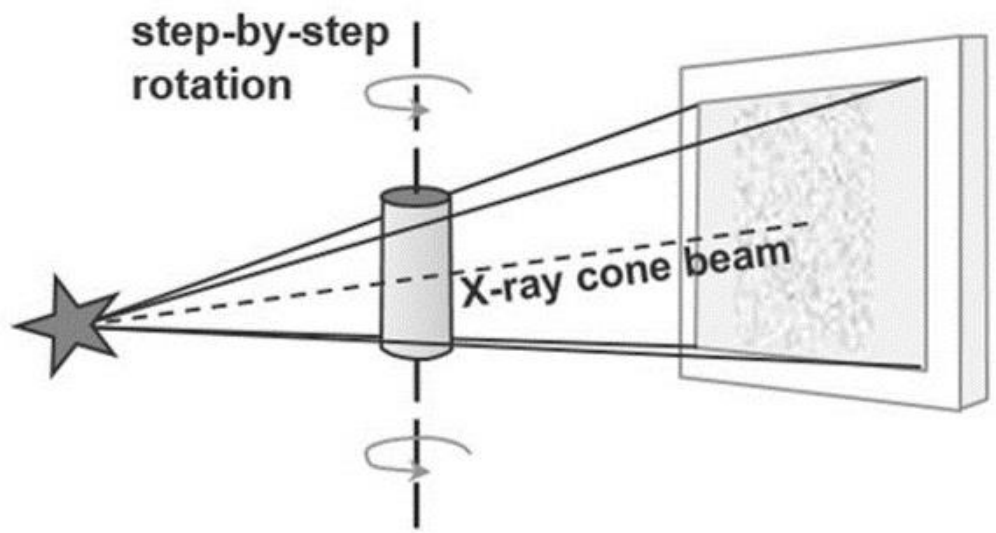

Figura 32 - Representação esquemática do processo de aquisição de imagens para TC. 


\subsection{Fratura e Análise dos Corpos de Prova}

Posterior às inspeções por UT-PA, Pulse-Eco e ToFD, RD e TC, os corpos de prova foram imersos em nitrogênio liquido, para que no momento da fratura a temperatura dos corpos de prova fosse bem abaixo da temperatura de transição dúctil-frágil, permitindo separar visualmente a região da trinca da região da fratura, além de necessitar de carga menor, não prejudicando assim a analise posterior da superfície fraturada (Figura 33).

As superfícies de fratura dos corpos de prova foram então analisadas com auxilio de uma lupa e software de analise de imagens para a medição das trincas e entalhes. As medições ocorreram de acordo com a norma ASTM E1820, que estipula nove medidas da trinca, sendo duas medidas laterais, sendo o comprimento da trinca uma media ponderada da média das laterais com as sete medidas “internas”, segundo a Equação 02:

trinca $=\frac{\frac{M_{l e}+M_{l d}}{2}+M_{1}+M_{2}+M_{3}+M_{4}+M_{5}+M_{6}+M_{7}}{8}$

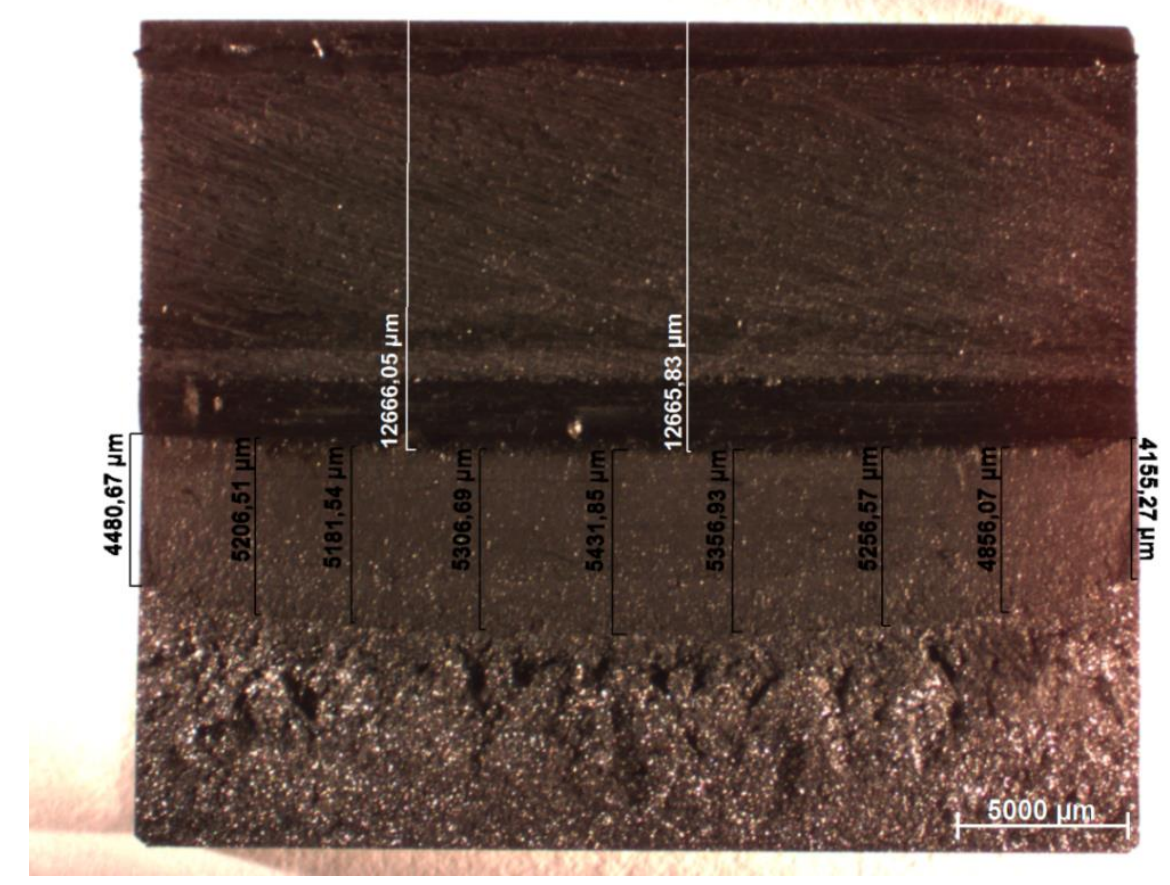

Figura 33 - Superfície de fratura e medição das trincas para o CP04. 


\section{Resultados e discussão}

\subsection{Medição Visual dos Tamanhos de Trinca}

Os valores das trincas $\left(a_{0}\right)$ nos corpos obtidos medidos diretamente na superfície de fratura, estão apresentados na Tabela 3, onde $\mathrm{M}_{\mathrm{le}}$ e $\mathrm{M}_{\mathrm{ld}}$ são as medidas das laterais das trincas. As medidas de M1 a M7 são medidas internas de comprimento das trincas. A Tabela 4, por sua vez, apresenta os valores médios do comprimento real da trinca $\left(a_{r}\right)$, das medias das medidas laterais $\left(M_{L}\right)$, do valor real do entalhe medido na superfície de fratura $\left(\mathrm{a}_{0} \mathrm{r}\right)$ e da medida real total da trinca $\left(a_{t \_} r\right)$, que é a soma das medidas reais das trincas e dos entalhes. As imagens das superficies de fratura com as medidas utilizadas na Tabela 5 se encontram no Anexo 01.

Tabela 3 - Medidas das trincas pela superfície de fratura.

\begin{tabular}{|c|c|c|c|c|c|c|c|c|c|}
\hline $\begin{array}{c}\text { Corpo de } \\
\text { prova }\end{array}$ & $\begin{array}{c}M_{\mathrm{le}} \\
(\mathrm{mm})\end{array}$ & $\begin{array}{c}\mathrm{M}_{1} \\
(\mathrm{~mm})\end{array}$ & $\begin{array}{c}\mathrm{M}_{2} \\
(\mathrm{~mm})\end{array}$ & $\begin{array}{c}\mathrm{M}_{3} \\
(\mathrm{~mm})\end{array}$ & $\begin{array}{c}\mathrm{M}_{4} \\
(\mathrm{~mm})\end{array}$ & $\begin{array}{c}\mathrm{M}_{5} \\
(\mathrm{~mm})\end{array}$ & $\begin{array}{c}\mathrm{M}_{6} \\
(\mathrm{~mm})\end{array}$ & $\begin{array}{c}\mathrm{M}_{7} \\
(\mathrm{~mm})\end{array}$ & $\begin{array}{c}\mathrm{M}_{\mathrm{ld}} \\
(\mathrm{mm})\end{array}$ \\
\hline $\mathrm{CP} 01$ & 2,78 & 3,23 & 3,40 & 3,43 & 3,43 & 3,35 & 3,23 & 3,15 & 2,60 \\
\hline $\mathrm{CP} 02$ & 5,56 & 6,91 & 7,31 & 7,51 & 7,71 & 7,81 & 7,76 & 7,31 & 6,43 \\
\hline $\mathrm{CP} 03$ & 4,08 & 4,61 & 4,91 & 4,91 & 5,06 & 5,01 & 4,93 & 4,61 & 4,08 \\
\hline $\mathrm{CP} 04$ & 4,48 & 5,20 & 5,18 & 5,30 & 5,43 & 5,36 & 5,26 & 4,86 & 4,16 \\
\hline
\end{tabular}


Tabela 4 - Valores das trincas calculados, da media lateral, do entalhe e da trinca total.

\begin{tabular}{|c|c|c|c|c|}
\hline Corpo de prova & $\begin{array}{c}\mathbf{a r} \\
(\mathbf{m m})\end{array}$ & $\begin{array}{c}\mathbf{M}_{\mathbf{L}} \\
(\mathbf{m m})\end{array}$ & $\begin{array}{c}\mathbf{a} \text { _r } \\
(\mathbf{m m})\end{array}$ & $\begin{array}{c}\mathbf{a} \_\mathbf{r} \\
(\mathbf{m m})\end{array}$ \\
\hline $\mathrm{CP01}$ & 3,24 & 2,60 & 2,99 & 6,23 \\
\hline $\mathrm{CP02}$ & 7,29 & 5,56 & 3,05 & 10,34 \\
\hline $\mathrm{CP03}$ & 4,76 & 4,08 & 3,14 & 7,90 \\
\hline $\mathrm{CP04}$ & 5,11 & 4,16 & 12,68 & 17,81 \\
\hline
\end{tabular}

\section{Ultrassom Phased Array}

Os valores das trincas $\left(a_{0}\right)$ nos corpos de prova e o erro relativo, obtidos pela inspeção por UT-PA Pulse-Eco (PE) esta apresentado na Tabela 5. A Tabela 6 mostra os valores de trinca e erro relativo da técnica de ToFD em comparação com o valor real do par trinca mais entalhe.

Tabela 5 - Valores de Trincas pelo método de PE, valor real da trinca e erro relativo.

\begin{tabular}{|c|c|c|c|c|c|c|c|c|c|}
\hline \multirow{2}{*}{$\begin{array}{c}\text { Corpo de } \\
\text { prova }\end{array}$} & \multicolumn{4}{|c|}{ a0 } & \multicolumn{4}{c|}{ erro } \\
\cline { 2 - 10 } & S1 & S1 & S2 & S2 & Real & S1 & S1 & S2 & S2 \\
& LA & LB & LA & LB & $(\mathbf{m m})$ & LA & LB & LA & LB \\
\hline CP04 & 17,0 & 18,6 & 18,9 & 19,0 & 17,81 & $-4,2$ & 4,8 & 6,5 & 7,0 \\
\hline CP03 & 3,8 & 4,9 & 7,6 & 7,0 & 7,90 & $-51,9$ & $-37,9$ & $-3,7$ & $-11,3$ \\
\hline CP02 & 10,7 & 10,5 & 11,4 & 11,4 & 10,34 & 3,6 & 1,7 & 10,4 & 10,4 \\
\hline CP01 & 3,9 & 4,4 & 7,4 & 7,2 & 6,23 & 37,5 & $-29,4$ & 18,7 & 15,5 \\
\hline
\end{tabular}


Tabela 6 - Valores de Trincas pelos métodos de ToFD, valore real da trinca e erro relativo.

\begin{tabular}{|c|c|c|c|c|c|}
\hline \multirow{2}{*}{$\begin{array}{c}\text { Corpo } \\
\text { de prova }\end{array}$} & \multicolumn{3}{|c|}{$\mathbf{a}_{\mathbf{0}}$} & \multicolumn{2}{c|}{ erro } \\
\cline { 2 - 6 } & \multicolumn{2}{|c|}{ ToFD (mm) } & Medida & \multicolumn{2}{c|}{ ToFD (\%) } \\
\cline { 6 - 7 } & S1 & S2 & $\begin{array}{c}\text { Real } \\
(\mathbf{m m})\end{array}$ & $\mathbf{S 1}$ & S2 \\
\hline CP04 & 17,9 & 18,3 & 17,81 & 0,8 & 3,1 \\
\hline CP03 & 7,2 & 5,3 & 7,90 & $-8,8$ & $-32,8$ \\
\hline CP02 & 10,9 & 10,5 & 10,34 & 5,6 & 1,7 \\
\hline CP01 & 3,2 & 7,7 & 6,23 & $-48,7$ & 23,5 \\
\hline
\end{tabular}

Os resultados apresentam uma discrepância principalmente para valores de trinca menores e entre diferentes superfícies, que pode ter tido como causa alguma não conformidade no processo de inspeção ou geometria de entalhe não favorável. De maneira general, a superfície 2 apresentou resultados melhores para as trincas de menor comprimento, ao passo que a superfície 1 apresenta valores de erro muito baixo para trincas maiores. Isso pode reforça a ideia que a trinca é mais bem detectada quanto mais próximo tiver da superfície inspecionada e que para os casos de trinca curta, que tem tamanho de trinca e entalhe próximos, ocorreu problema com ruído do entalhe superpondo o sinal da trinca. Na Figura 34 podemos observar, pelo método ToFD no CP02 (itens (a) e (b)) e CP04 (itens (c) e (d)), que na superfície 1, o sinal apresentou um grande ruído (Figura 34 a.) e que na superfície 2 o sinal apresentou baixa amplitude, o que provavelmente ocorreu devido a superposição do sinal gerado pelo entalhe sobre o sinal gerado pela trinca. Os itens (a) e (b) da Figura 34 demonstram o ruído e a baixa amplitude, respectivamente, e o itens (c) e (d) demonstram um sinal mais "limpo" de sinal e com uma intensidade mais adequada. As outras imagens geradas na inspeção por UT-PA estão no Anexo 02. 


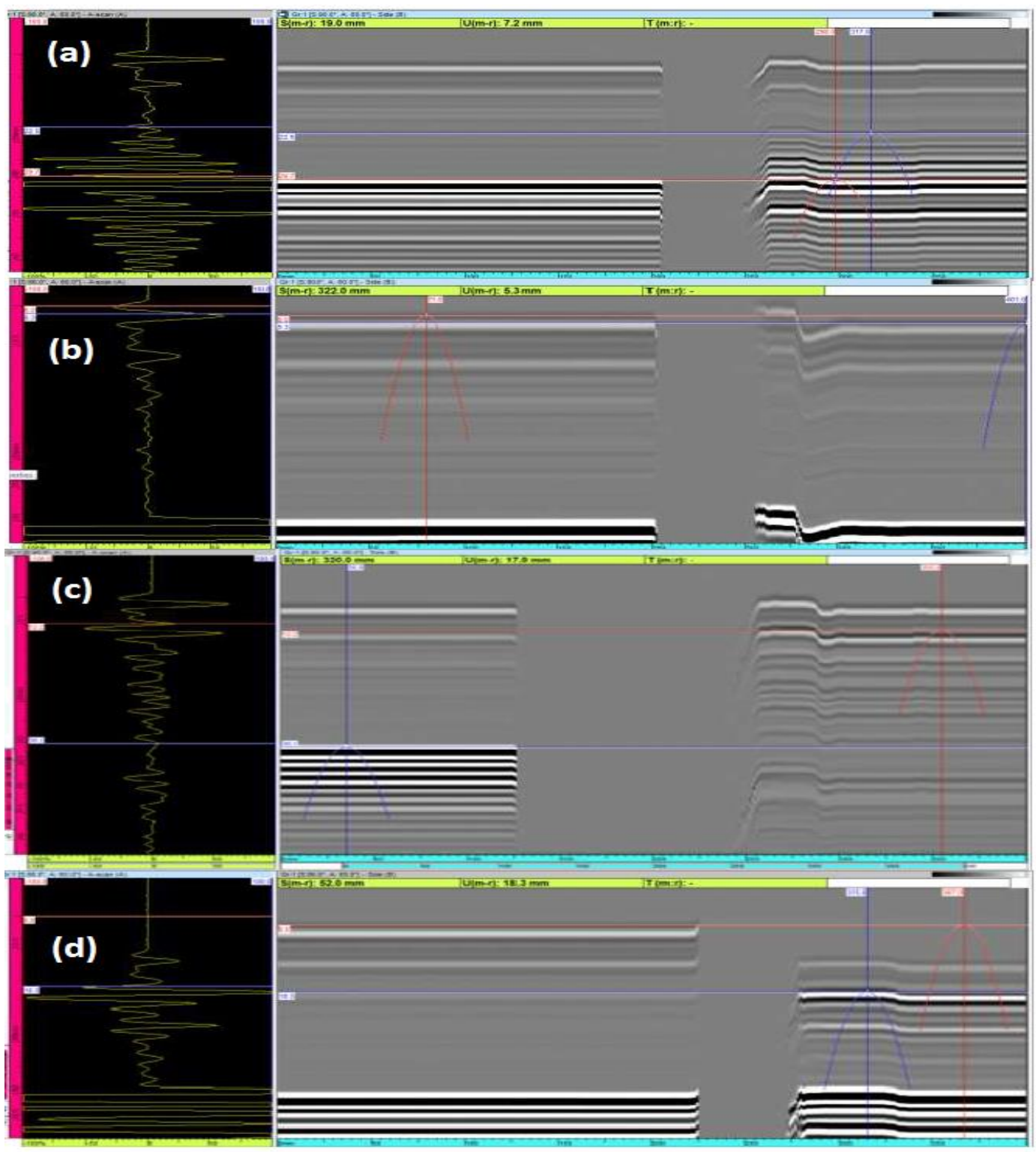

Figura 34 - ToFD dos CP01, itens (a) e (b); e CP02, itens (a) e (b);

\subsection{Radiografia Digital}

Esta técnica permitiu indicar e mensurar a trinca pela medida lateral (Figura 36 do CP04). Devido à característica da trinca de ser um defeito quasi-planar, a visualização da mesma pela vista lateral fica comprometida, principalmente devido a espessura e densidade do material dos corpos de prova, o que acarreta uma grande atenuação de raios $X$, resultando na necessida da aplicação de filtros na imagem para que possa visualizar a trinca, acarretando um borramento na imagem em locais 
com grande diferença de incisão de raios $\mathrm{X}$, por exemplo, entre o corpo de prova e o vazio do entalhe, como pode ser observado na Figura 35. Além disso, a trinca na imagem apresenta uma espessura de apenas duas linhas de pixel $(<1 \mathrm{~mm})$, o que dificultou uma medição mais precisa. A Tabela 07 apresenta os valores da medida lateral das trincas por $\mathrm{RD}\left(\mathrm{R}_{\mathrm{L}}\right)$, da medida lateral das trincas real $\left(a_{t r}\right)$, dos erros relativos entre $\mathrm{R}_{\mathrm{L}}$ e a medida real da trinca. As outras imagens da RD se encontram no Anexo 03.

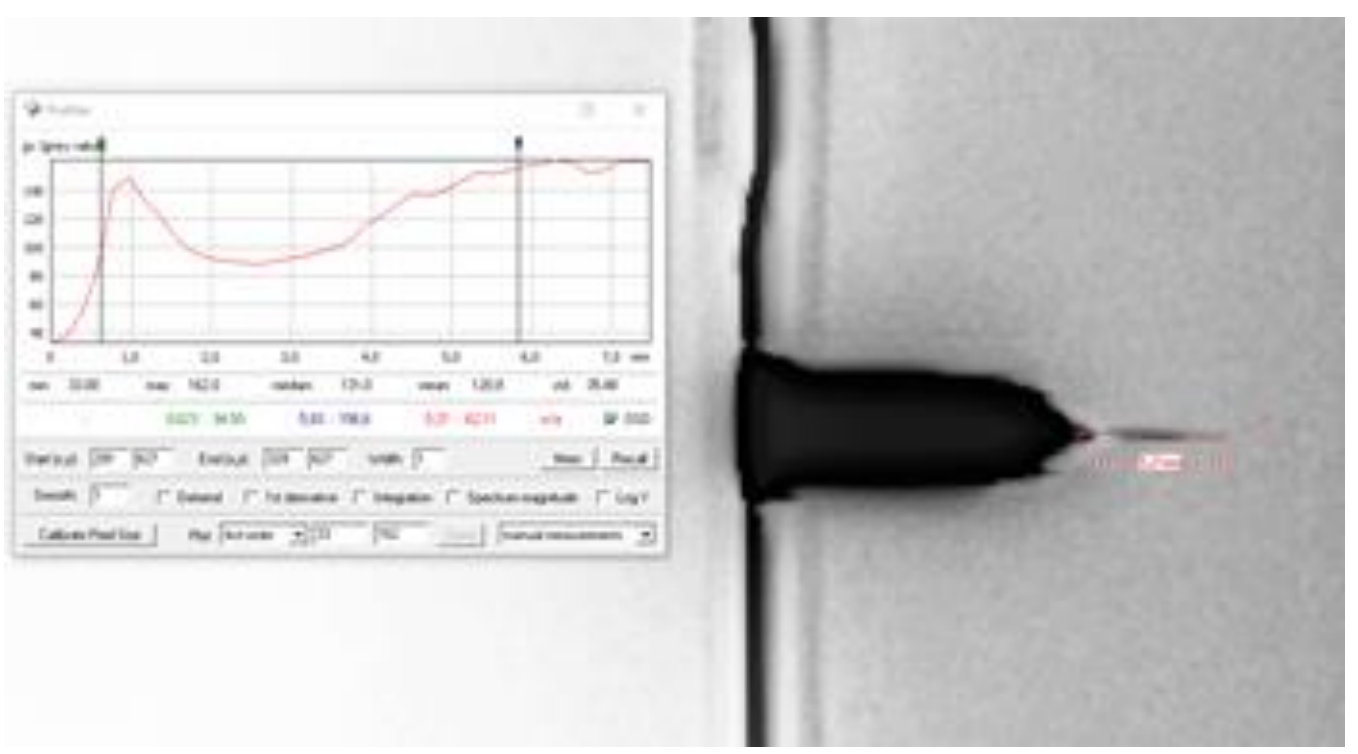

Figura 35 - Medida lateral da trinca do CP04.

Tabela 7 - Valor da medida por RD da trinca, comparação com a medida lateral da trinca real e ao tamanho total da trinca.

\begin{tabular}{|c|c|c|c|c|c|}
\hline Corpo de Prova & $\begin{array}{c}\text { Medida } \\
\text { RD } R_{\mathbf{L}} \\
(\mathbf{m m})\end{array}$ & $\begin{array}{c}\text { Medida } \\
\text { Lateral } \\
\boldsymbol{a}_{t r}(\mathbf{m m})\end{array}$ & Erro (\%) & $\begin{array}{c}\text { Valor } \\
\text { Real } \boldsymbol{a}_{t r} \\
(\mathbf{m m})\end{array}$ & Erro (\%) \\
\hline CP01 & 2,42 & 2,58 & $-6,1$ & 3,24 & $-25,3$ \\
\hline CP02 & 6,47 & 5,56 & 16,4 & 7,29 & $-11,2$ \\
\hline CP03 & 4,12 & 4,08 & 1,0 & 4,76 & $-13,5$ \\
\hline CP04 & 5,21 & 4,16 & 25,4 & 5,11 & 1,9 \\
\hline
\end{tabular}

Embora na RD a imagem da lateral da trinca fique mais evidente, mesmo quando comparada a indicação lateral mais entalhe da RD com os valores reais, a $\mathrm{RD}$ apresentou valores razoáveis de erro, comparáveis aos encontrados pelas 
técnicas de UT-PA (Tabela 6). Os valores para somente a medida lateral da trinca também foram satisfatórios. Os erros para o CP04 ficaram fora do esperado, provavelmente devido a uma pequena deformação plástica que ocasionou a abertura da ponta trinca, portanto a medida da lateral da trinca por RD, pra este caso, indicou uma medida mais central da trinca.

\subsection{Tomografia Computadorizada}

A inspeção por TC foi performada buscando uma melhor visualização da trinca, pois permite gerar uma imagem em três dimensões, porém, devido à geometria/densidade dos corpos de prova e dos parâmetros do equipamento que realiza a aquisição das imagens, houve um desafio em identificar, mensurar e visualizar as trincas, apenas no CP04 foi possível mensurar com mais clareza (Figura 36) e visualizar a trinca no seu plano de propagação, no entanto, não foi possivel ser gerada a imagem tridimensional da trinca. A Tabela 08 apresenta os valores da medida lateral das trincas por $\mathrm{TC}\left(\mathrm{T}_{\mathrm{L}}\right)$, da medida lateral das trincas real $\left(a_{t r}\right)$, do erros relativos entre $\mathrm{R}_{\mathrm{L}}$ e a medida real da trinca As outras imagens da TC se encontram no Anexo 04.

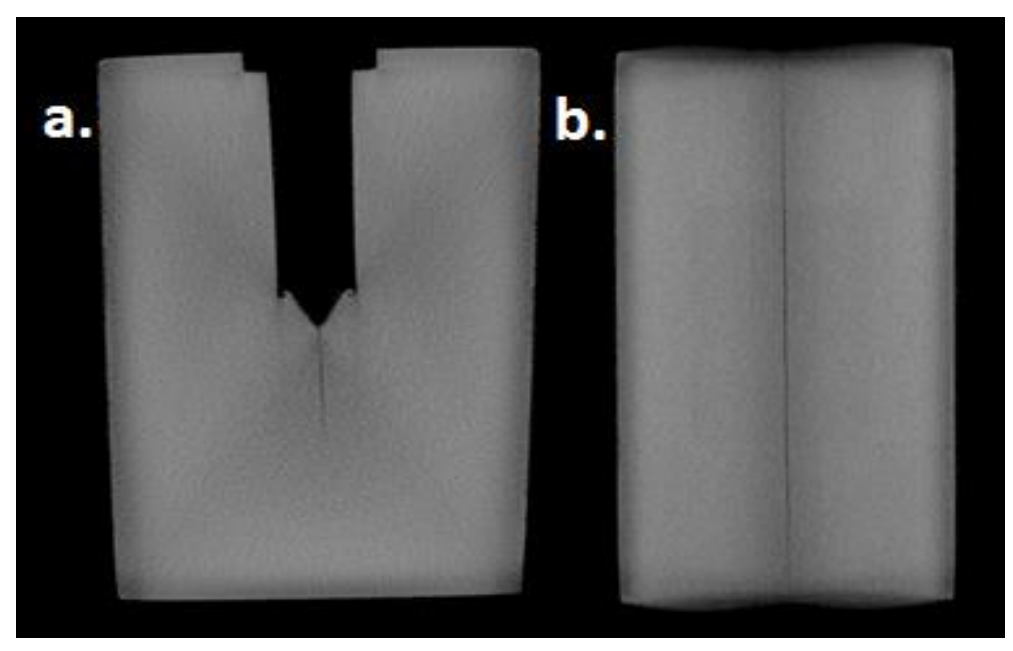

Figura 36 - TC do CP04 pela a. vista lateral; b. corte longitudinal. 
Tabela 8 - Valor da medida por TC da trinca, comparação com a medida lateral da trinca real e ao tamanho total da trinca.

\begin{tabular}{|c|c|c|c|c|c|}
\hline Corpo de Prova & $\begin{array}{c}\text { Medida } \\
\text { RD T } \\
(\mathbf{m m})\end{array}$ & $\begin{array}{c}\text { Medida } \\
\text { Lateral } \\
\boldsymbol{a}_{t r}(\mathbf{m m})\end{array}$ & Erro (\%) & $\begin{array}{c}\text { Valor } \\
\text { Real } \boldsymbol{a}_{t r} \\
(\mathbf{m m})\end{array}$ & Erro (\%) \\
\hline CP01 & 2,89 & 2,58 & $-6,1$ & 6,23 & $-13,2$ \\
\hline CP02 & 5,55 & 5,56 & 16,4 & 10,34 & $-7,9$ \\
\hline CP03 & 1,77 & 4,08 & 1,0 & 7,90 & $-8,1$ \\
\hline CP04 & 5,6 & 4,16 & 25,4 & 17,81 & 0,5 \\
\hline
\end{tabular}

Os valores obtidos pela TC foram próximos dos indicados pela $\mathrm{RD}$, exclusive o CP03, a TC apresentou uma imagem mais nítida do defeito (Figura 36), porém com erro um pouco maior, possivelmente devido a erro humano no momento de medição da trica. Essa similaridade pode ser explicada pela natureza da aquisição de imagens (atenuação de raios X).

Os corpos de prova foram retrabalhados para diminuir o volume de material na redondeza do defeito, na tentativa de se adequar ao equipamento de TC, porém, o volume restante continuou sendo excessivo, melhorando a resolução e clareza do ensaio, mas não possibilitando explorar as ferramentas, como imagem tridimensional, da TC. Para que fosse permitido utilizar a geometria/densidade atual, o equipamento de $\mathrm{TC}$ teria que gerar um feixe de raios $\mathrm{X}$ de uma maior intensidade, ultrapassando o permitido pelo equipamento utilizado, ou a razão entre o volume de material a volta da trinca e o volume da trinca deverá ser menor. 


\subsection{Comparação entre Técnicas}

Conforme pode ser observado na Figura 37, os resultados não seguem um padrão bem definido. Os ensaios pelas técnicas de UT-PA na superfície 2 superdimensionaram as trincas, majoritariamente, demonstrando um maior constância de resultados, o que pode ser traduzido em confiabilidade nas medidas indicadas pela técnica nesta orientação de superfície.. Já para a superfície 1, em metade das amostras o valor ficou abaixo do valor real e na outra parcela o defeito também foi superdimensionado, porém com um erro menor se comparado a superfície 2. Essa discrepância para técnicas de UT-PA pode ser explicada por um erro no momento da inspeção, seja humano ou procedimental, e geometria do entalhe desfavorável, pois apresentou um ruído elevado para medição com precisão das trincas. Caso tal ruído não estivesse presente, seria possível mensurar as trincas com maior precisão, como foi o caso do para os corpos de prova com valores maiores de trinca (CP02 e CP04).

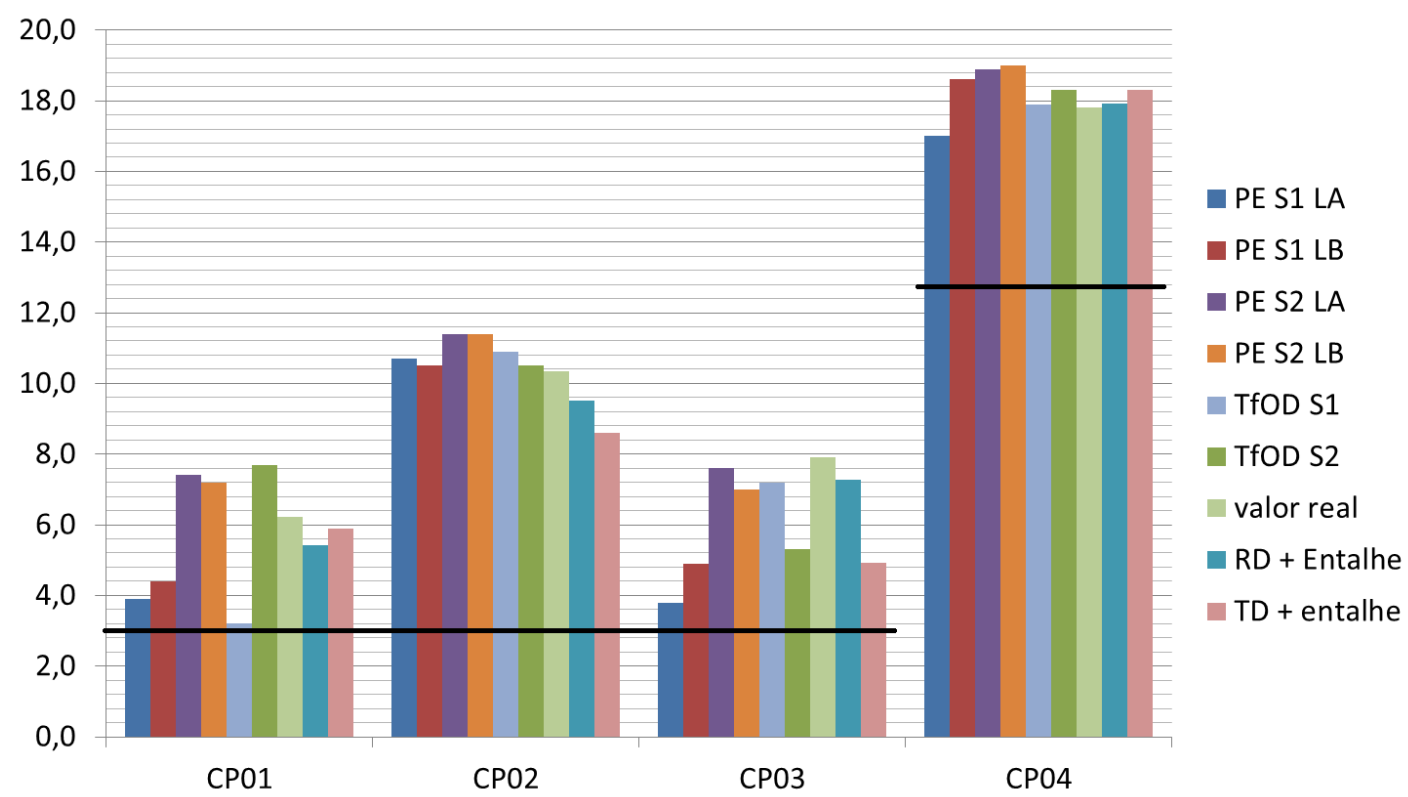

Figura 37 - Gráfico com o valor de trinca mais entalhe pra todas as técnicas de END e o valor real da trinca.

As técnicas de RD e TC subdimensionaram os tamanhos de trinca, devido à indicação e medição dos defeitos ter sido feito pela vista lateral, sendo então o tamanho indicado por essas técnicas mais próximas da medida lateral da trinca, que 
por sua vez tem dimensão menor devido ao formato da trinca (Figura 33). Se as medidas indicadas por essas técnicas forem comparadas apenas com o valor da lateral da trinca real, o erro absoluto passa a ser inferior ao erro absoluto quando se compara estas técnicas com o valor real calculado das trincas. O gráfico com os valores da medida lateral das técnicas e da medida lateral real da trinca está apresentado na Figura 38.

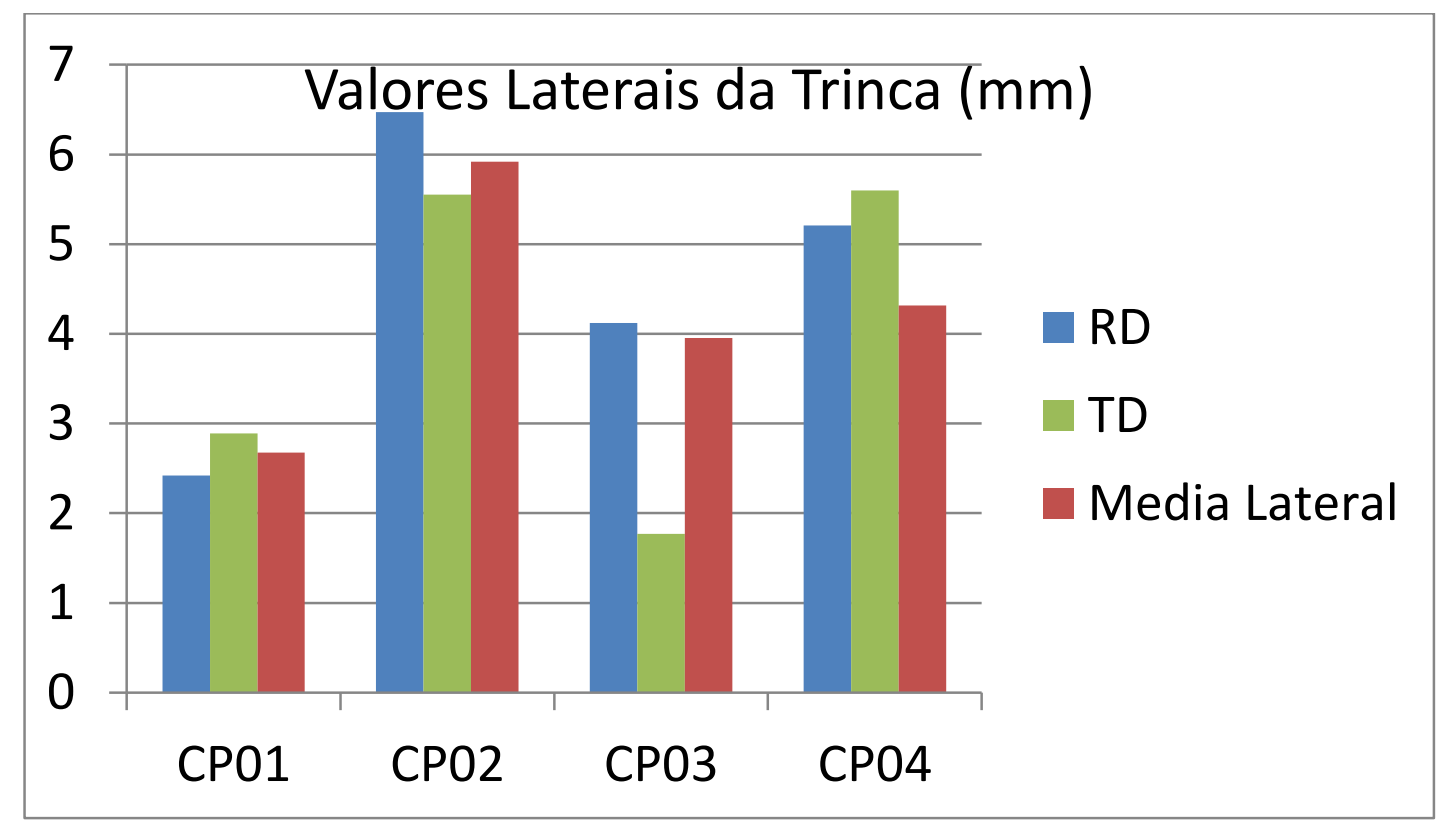

Figura 38 - Gráfico com os valores de media lateral real da trinca e medida indicada pelas técnicas de TC e RD. 


\section{Conclusões}

O objetivo do presente trabalho foi determinar a assertividade de diferentes técnicas de Ensaios Não Destrutivos, sendo elas o Ultrassom Phased Array, nos métodos de Pulso-Eco e Time of Flight Diffration, Radiografia Digital e Tomografia Computadorizada, quanto ao dimensionamento de trincas de fadiga em corpos de prova de aço DIN 42CrMo4. Baseados nos resultados obtidos e sobre observação e preparação das inspeções, pode ser concluir que:

- A técnica de Pulso-Eco apresentou valores conservadores para a superfície de inspeção coincidente e perpendicular a raiz do entalhe e valores satisfatórios para tamanhos de trinca maiores e não conservadores pra tamanhos menores de trinca, na inspeção da superfície oposta.

- A técnica ToFD também apresentou erros baixos para tamanhos maiores de trinca e medidas dispersas para valores de trinca menores, em ambas as superfícies, devido a ruído no sinal.

- Ambos os métodos de Ultrassom Phased Array apresentaram valores de medida de trinca similares para a superfície que contem o entalhe e valores disperso na inspeção pela superfície oposta dos corpos de prova com menores valores de trinca, o que pode indicar uma sensibilidade, destes ensaios nessa orientação, à geometria do entalhe.

- Ambas as técnicas de Radiografia Digital e Tomografia Digital indicaram valores não conservadores se comparados com os valores reais das trincas, sendo um ônus deste tipo de inspeção. Já quando comparado aos valores das laterais de trinca essas técnicas indicaram valores próximos ou superiores ao valores reais das laterais das trincas.

- Majoritariamente, as técnicas por UT-PA são mais conservadoras quanto aos valores das trincas, em comparação com as técnicas variantes do ensaio radiográfico. 


\section{Sugestões para trabalhos futuros}

Com intuito de aperfeiçoar o corpo de prova à inspeção por UT-PA deverá ser utilizado um corpo de prova com a mesma geometria ou mesmo fator geométrico, todavia com geometria diferente para o entalhe, de modo a diminuir o ruído gerado pelo mesmo. Outra sugestão é utilizar uma geometria similar a atual, porém com a seção transversal retangular, o que permitirá a inspeção em todas as faces do corpo de prova perpendiculares ao plano de propagação de trincas, porem, a modificação da geometria do entalhe continua necessária.

Se o intuito for estudar melhor a técnica de TC, fica recomendada a utilização da menor razão admissível entre o volume de material nas redondezas do defeito e o volume do defeito a fim de minimizar a difração dos raios $\mathrm{X}$ e maximizar a resolução e qualidade da imagem gerada.

Uma outra abordagm seria a de avaliar chapas ou tubos soldados que apresentem ou tenham sido induzidos uma trinca em sua solda. Tal abordagem permitiria ser realizada a varredura do defeito pela técnicas de UT-PA e uma melhor comparação com as técnicas de RD e TC no que tange a aplicações mais usuais. 


\section{Referências bibliográficas}

AMERICAN SOCIETY FOR TESTING AND MATERIALS. ASTM E1820:

Standard test method for measurement of fracture toughness. USA, 2017.

AMERICAN SOCIETY FOR TESTING AND MATERIALS. ASTM E1290: Standard test method for Crack-Tip Opening Displacement (CTOD) Fracture Toughness. USA, 2008.

Andreucci, R. Ensaio por Ultrassom. Associação Brasileira de Ensaios Não Destrutivos, 2017

Andreucci, R. Radiografia Industrial. Associação Brasileira de Ensaios Não Destrutivos, 2017

Berke, M. Nondestructive Material Testing with Ultrasonics. Site: www.ndt.net/article/v05n09/berke/berke/pdf. Acessado em: 08/dez/17.

Costa, A. D.; Marriel, M. Avaliação de Tecnicas de dimensionamento da altura das descontinuidades detectadas por ensaio ultrassonico e suas aplicações. ConaEND\&IEV 2014

Einav, I. et. Al. Non-destructive testing for plant life assessment. IAEA - International Atomic Energy Agency, Vienna, 2005.

International Organization for Standardization. ISO 15653: Mettalic materials - Method of test for the determination of quasistatic fracture toughness of welds. USA, 2010. 
Molica Nardo, R.; Cerniglia, D.; Lombardo, P.; Pecoraro, S.; Infantino, A. Detection, characterization an sizing of hydrogen induced cracking in pressure vessels using phased array ultrasonic data processing. Procedia Structural Integrity 2, 2016, p. 581-588.

NDT Resource Center. Ciência e engenharia de materiais: uma introdução. $8^{\mathrm{a}}$ ed. LTC, Rio de Janeiro, 2013. 817p.

Richter, M. Uso das Técnicas de END: Ultrassons (TOFD e Phased ARRAY), Radiografia, Particulas Magnéticas e ACFM na avaliação de Juntas Soldadas com Trincas de Fadiga. IV Conferencia Pan-americana de END, Buenos Aires, 2007.

Tech, R. Introduction to Phased Array Ultrasound Technology Applications. RD Tech Guideline, Canada, 2004.

Nilsson, K.; Ripplinger, S.; Ruiz, A.; Bruchhausen, M.; Fischer, B.; Gupta, $M$. Analysis of Crack Morphologies and Patterns from Thermal Fatigue using X-ray Tomography. Procedia Structural Integrity 3, 2014, p. 21802186. 
Anexos

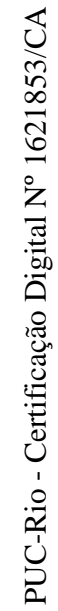


Anexo 01 - Medição das Trincas:

- $\mathrm{CP} 01$
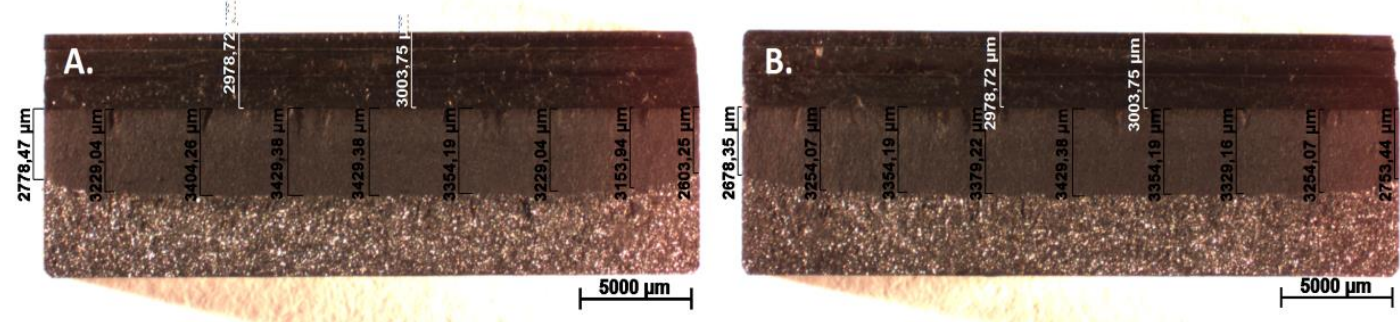

- $\mathrm{CP} 02$
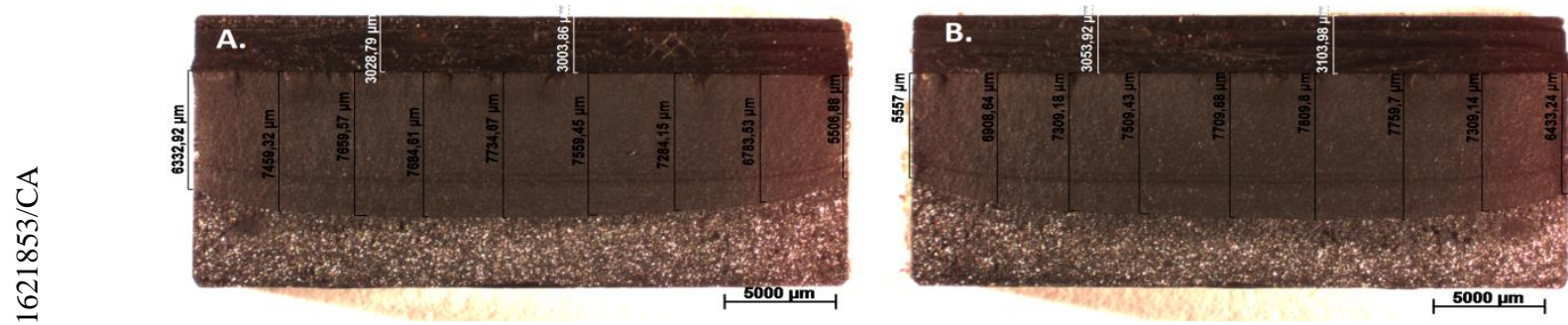

- $\mathrm{CP03}$
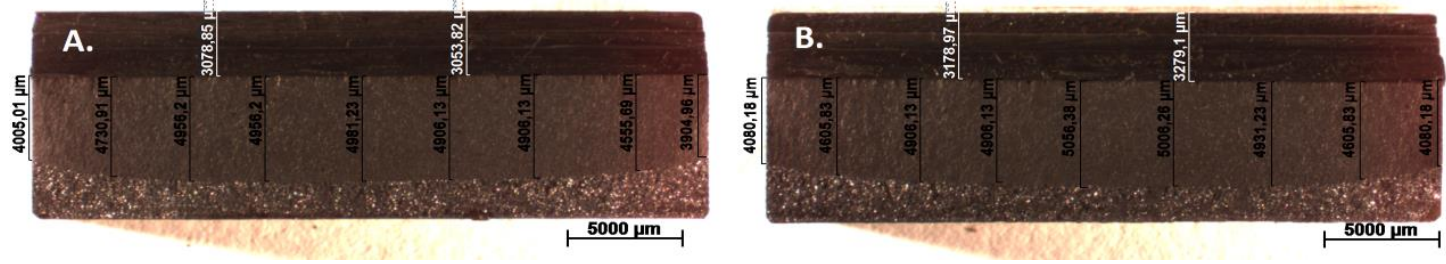

- $\mathrm{CP04}$

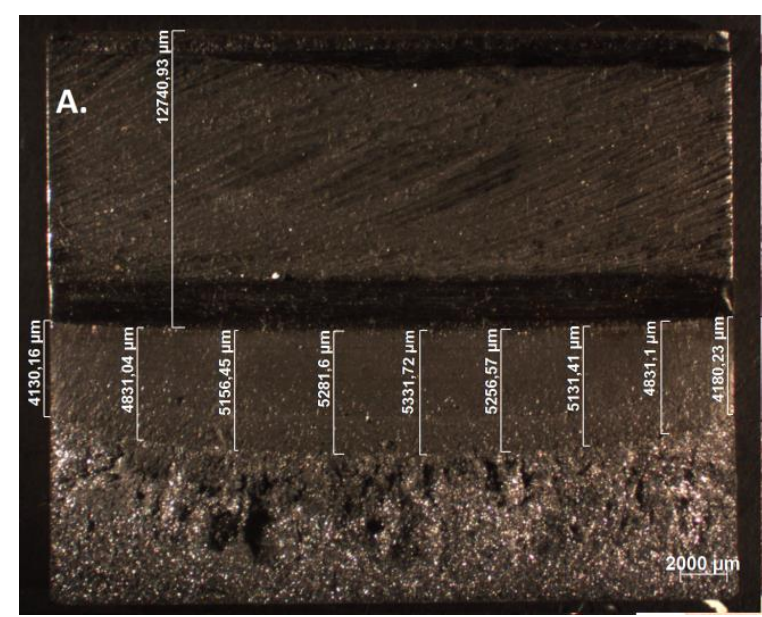

B. 


\section{Anexo 02 - Resultados UT-PA:}

- CP01 - Pulso-Eco

Região de contato: Superfície 1 Lado A

Altura (h): $3,9 \mathrm{~mm}$

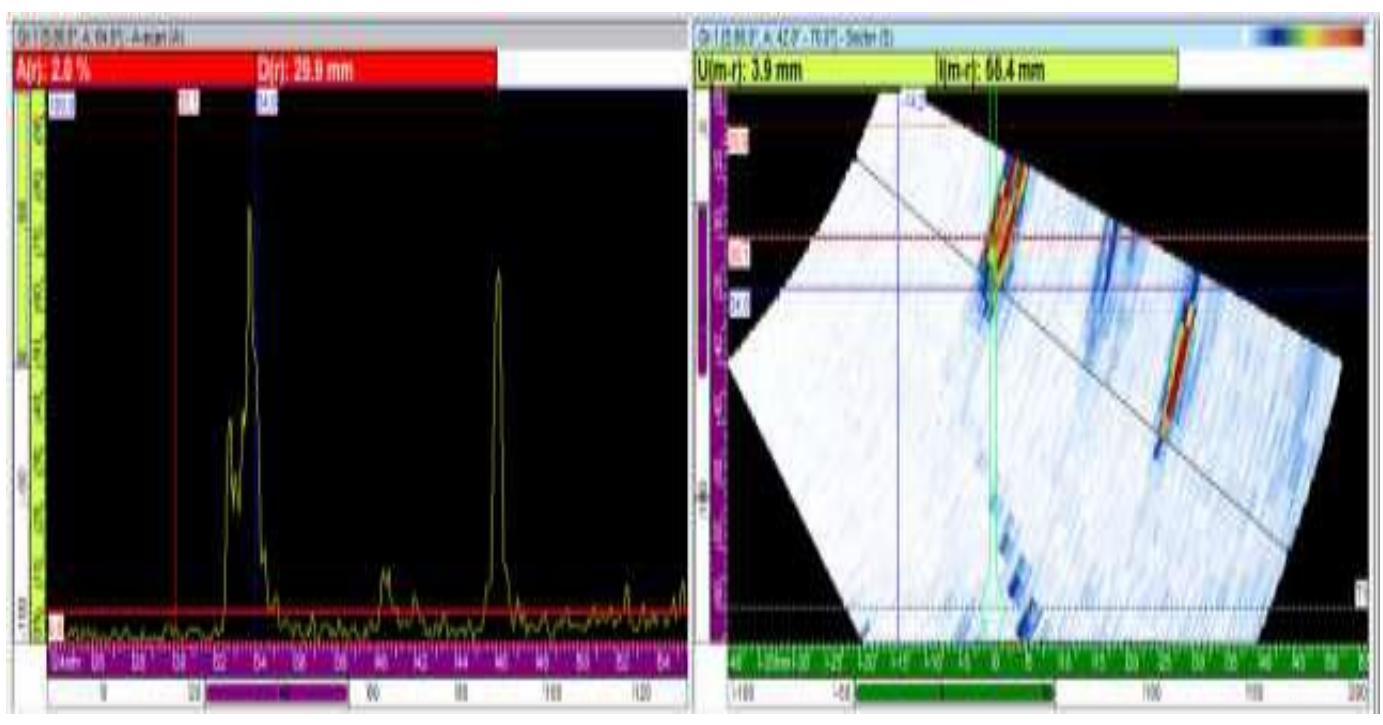

Região de contato: Superfície 1 Lado B

Altura (h): 4,4 mm
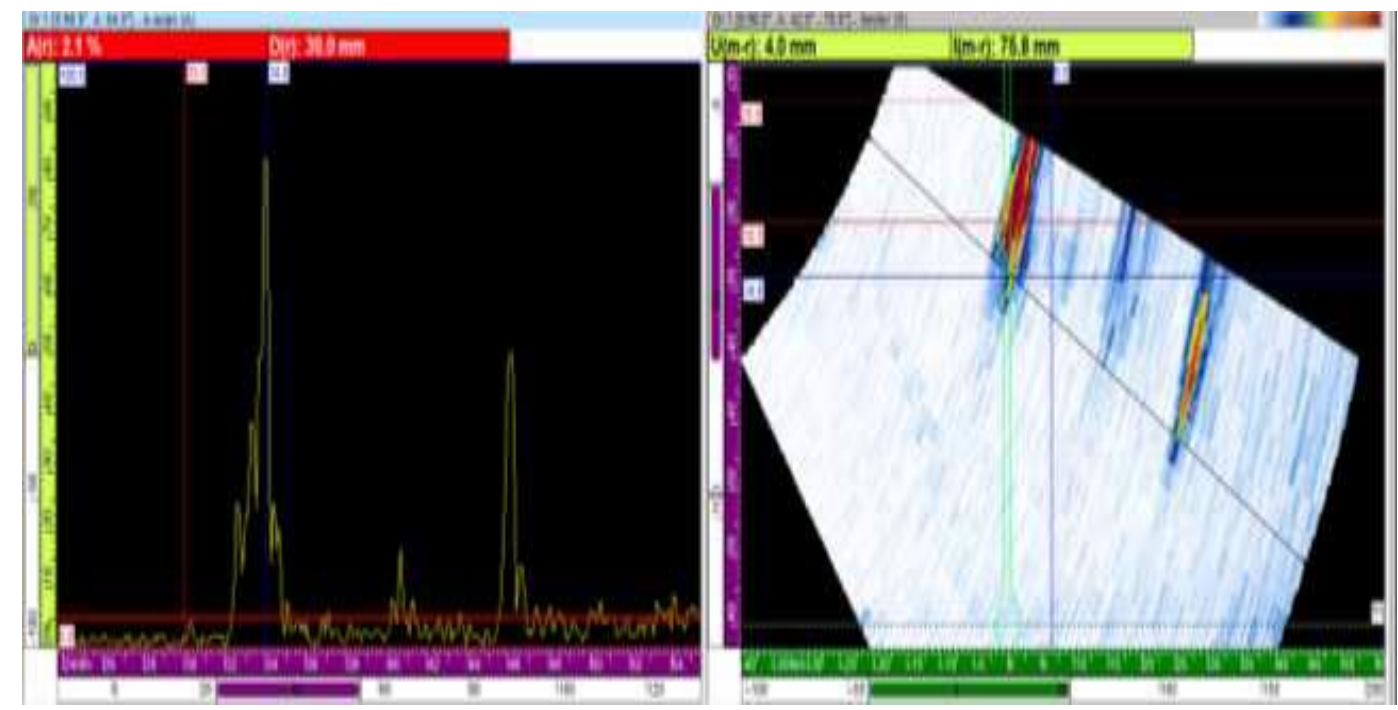
Região de contato: Superfície 2 Lado A

Altura (h): $7.4 \mathrm{~mm}$

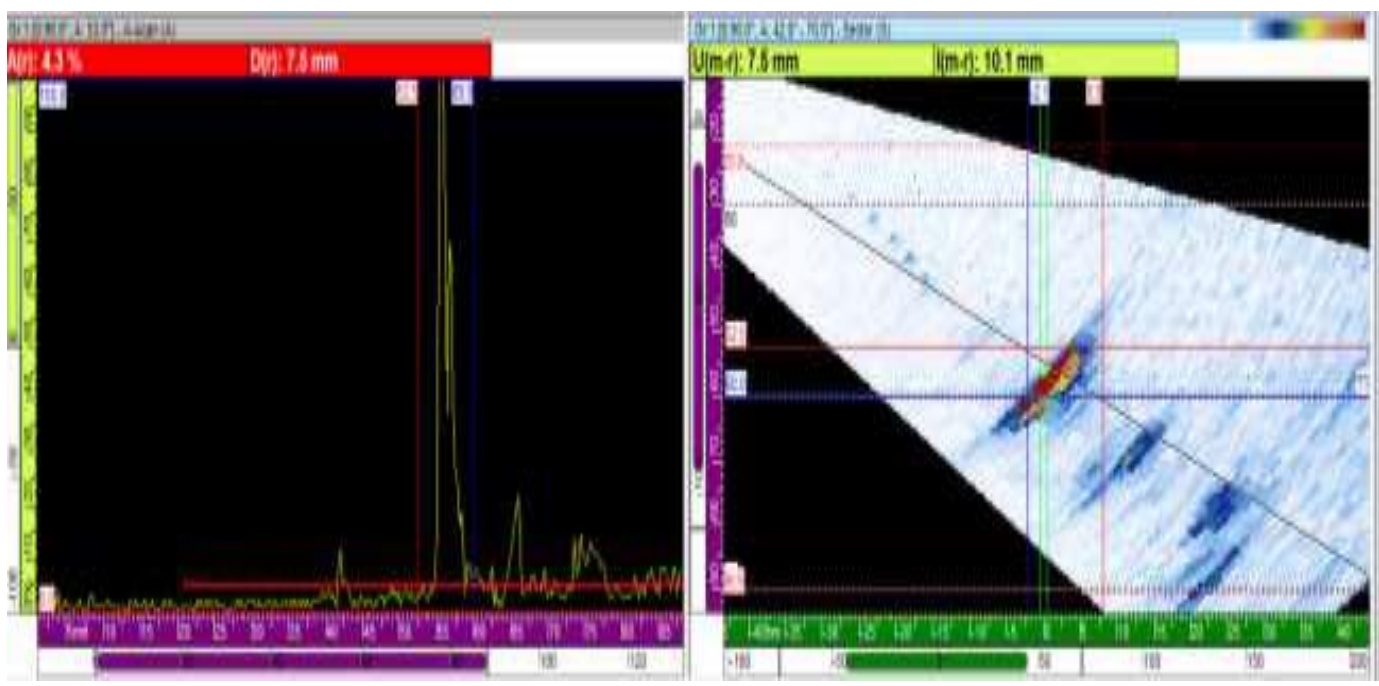

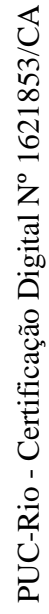

Região de contato: Superfície 2 Lado B

Altura (h): $7.2 \mathrm{~mm}$

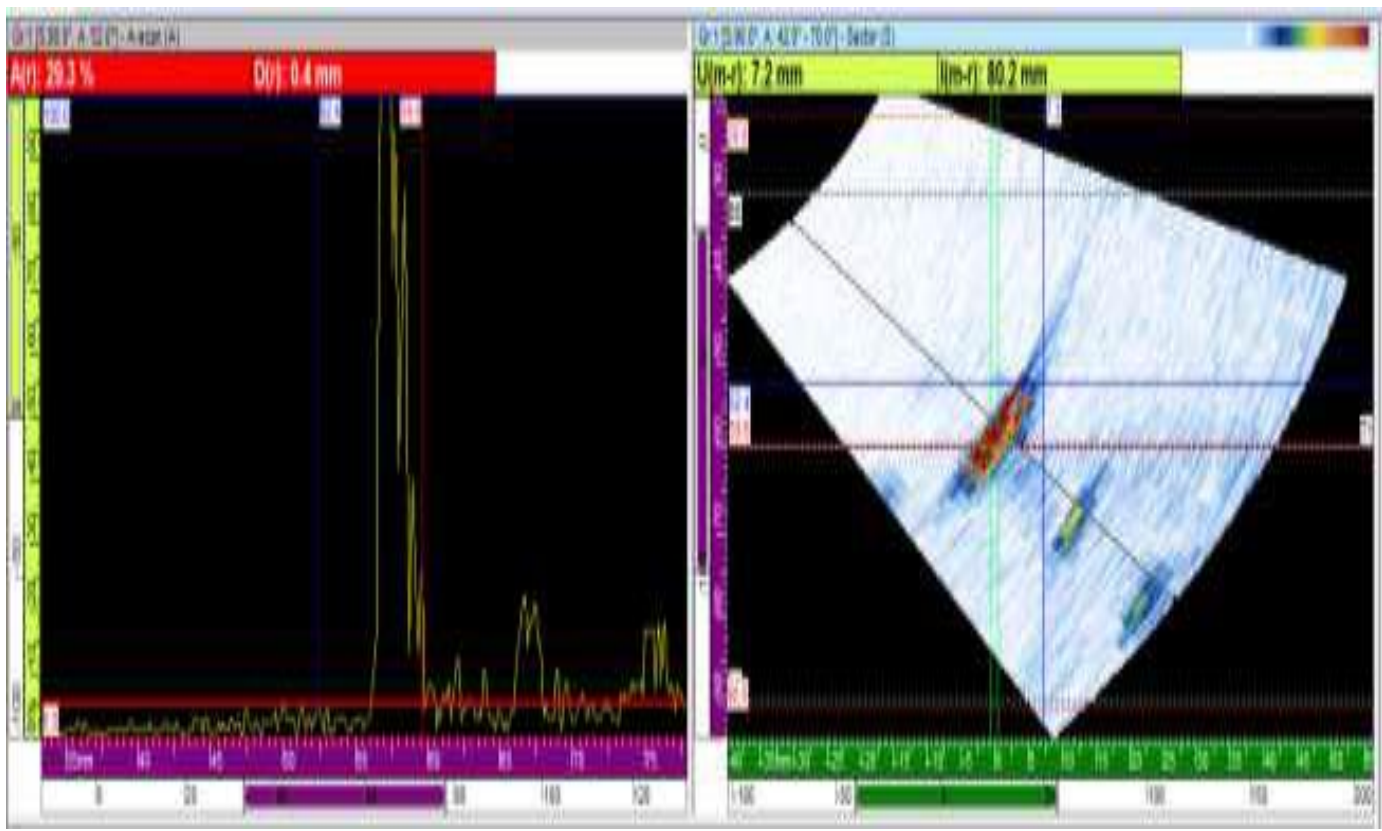


- CP01 - ToFD

Região de contato: Superfície 1 Altura (h): $3.2 \mathrm{~mm}$

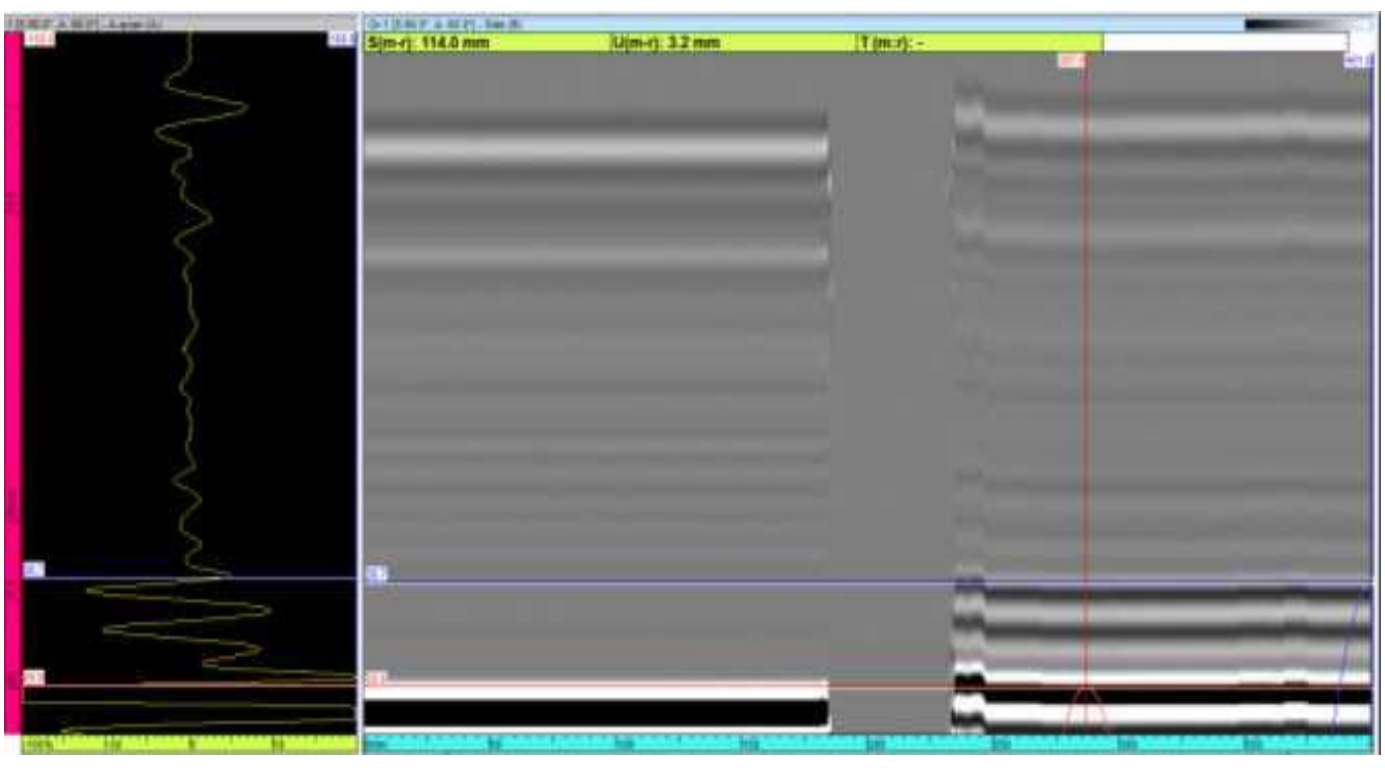

Região de contato: Superfície 2 Altura (h): $7.7 \mathrm{~mm}$

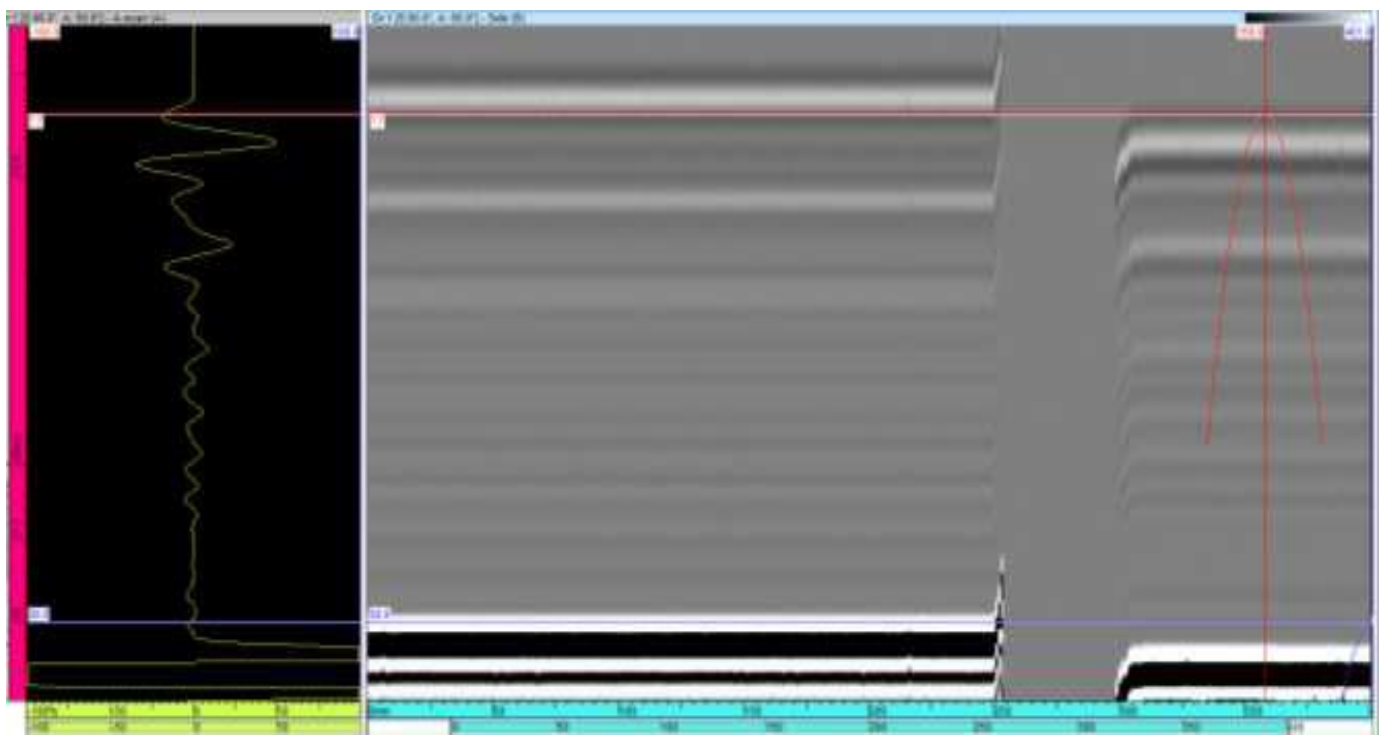


- CP02 - Pulso-Eco

Região de contato: Superfície 1 Lado A

Altura (h): $10.7 \mathrm{~mm}$

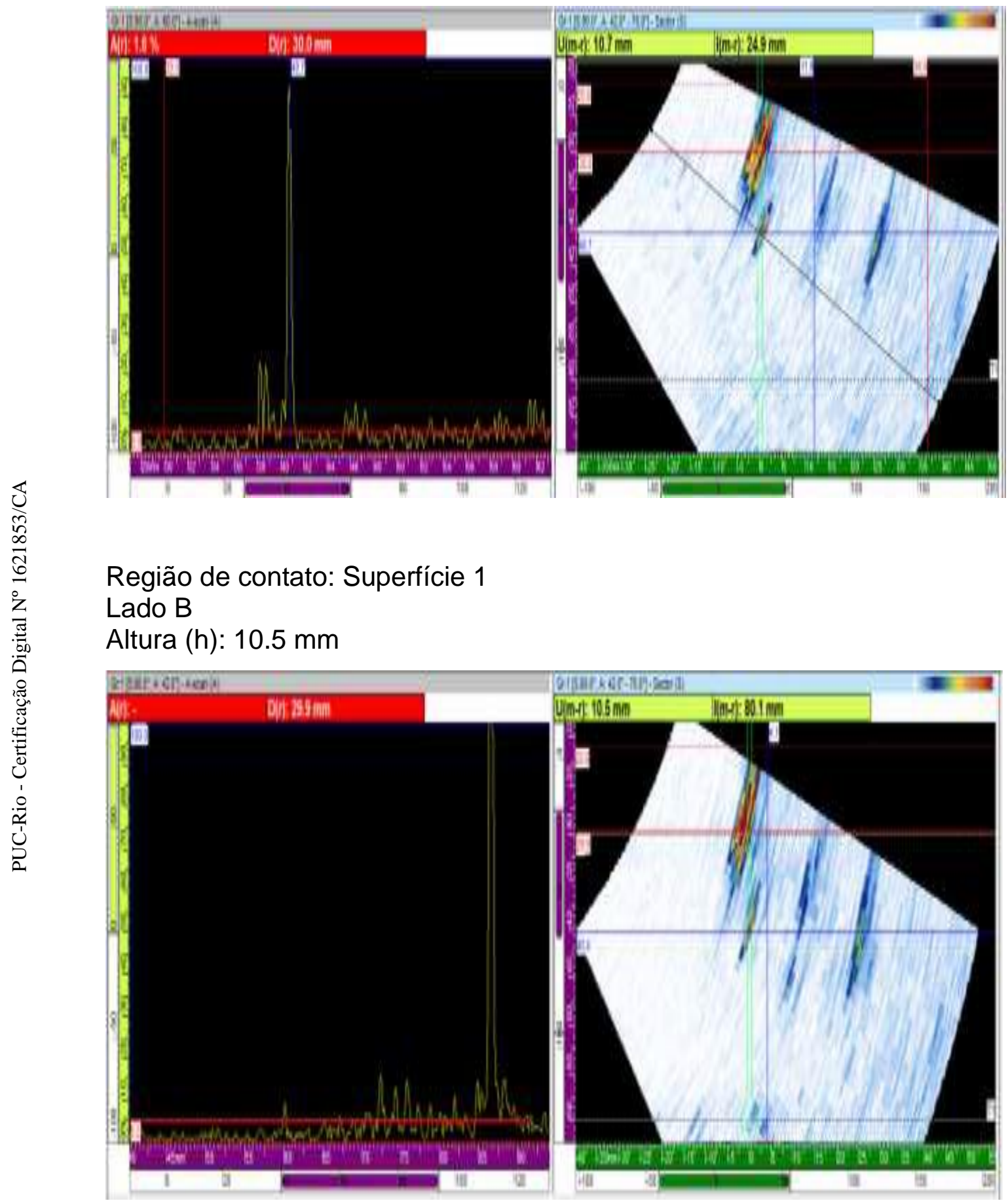


Região de contato: Superfície 2 Lado A

Altura (h): $11.4 \mathrm{~mm}$

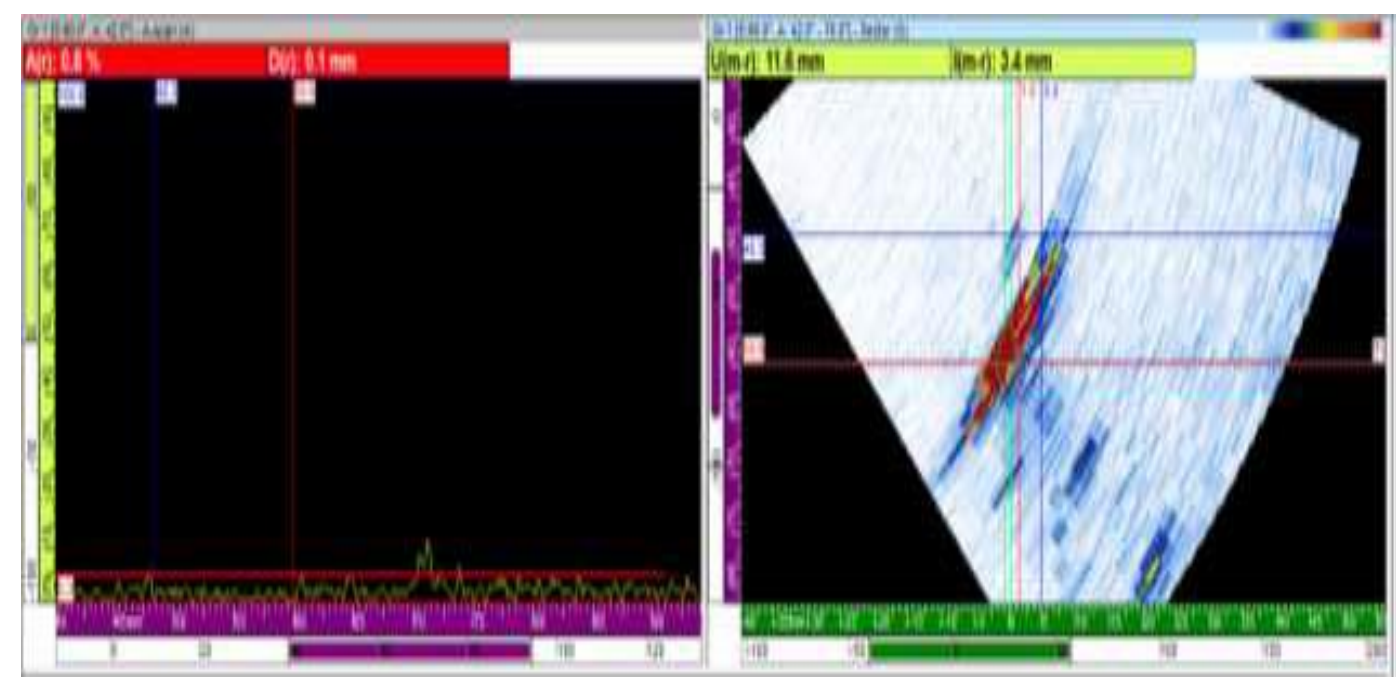

Região de contato: Superfície 2 Lado B

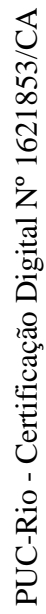

Altura (h): $11.4 \mathrm{~mm}$

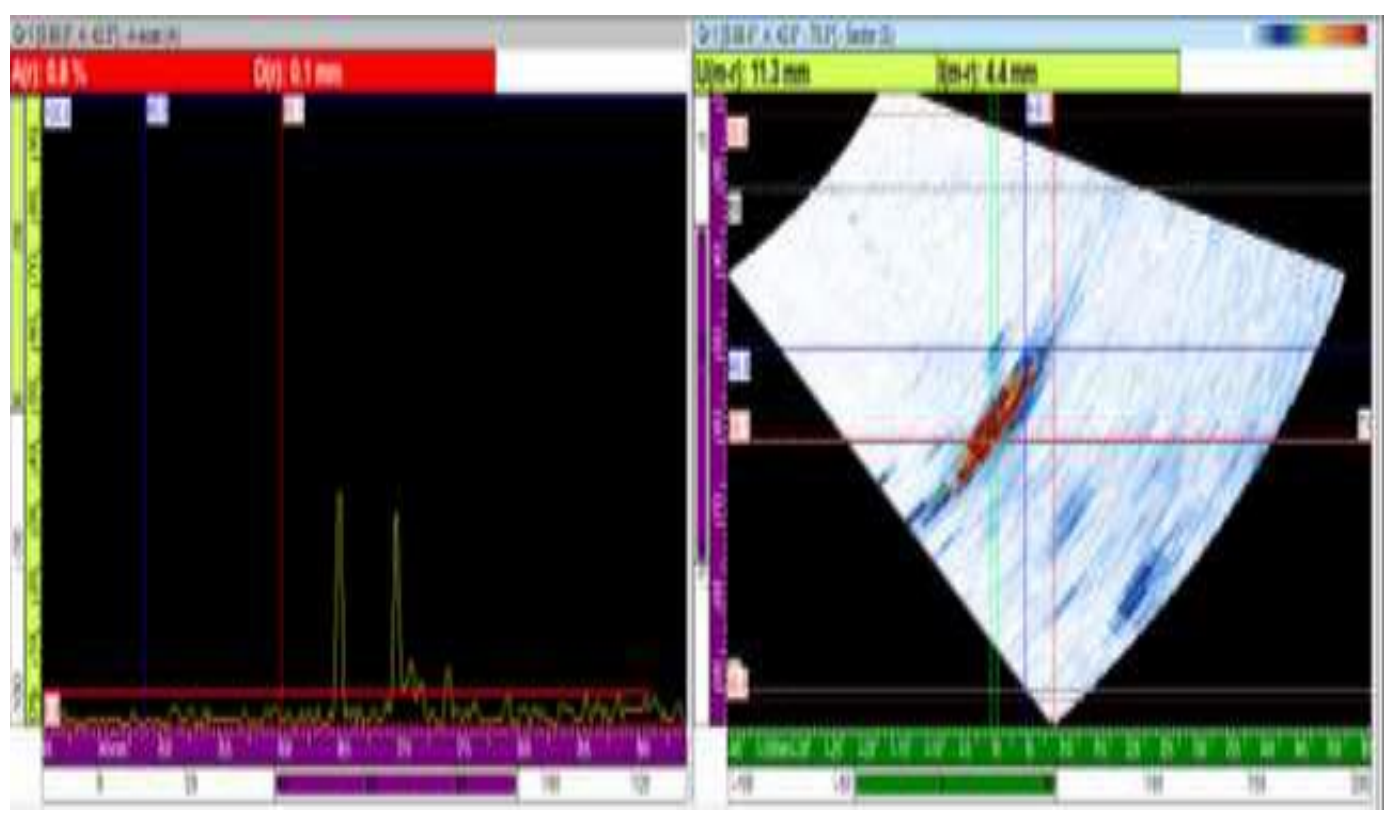


- CP02 - ToFD

Região de contato: Superfície 1

Altura (h): $10.9 \mathrm{~mm}$

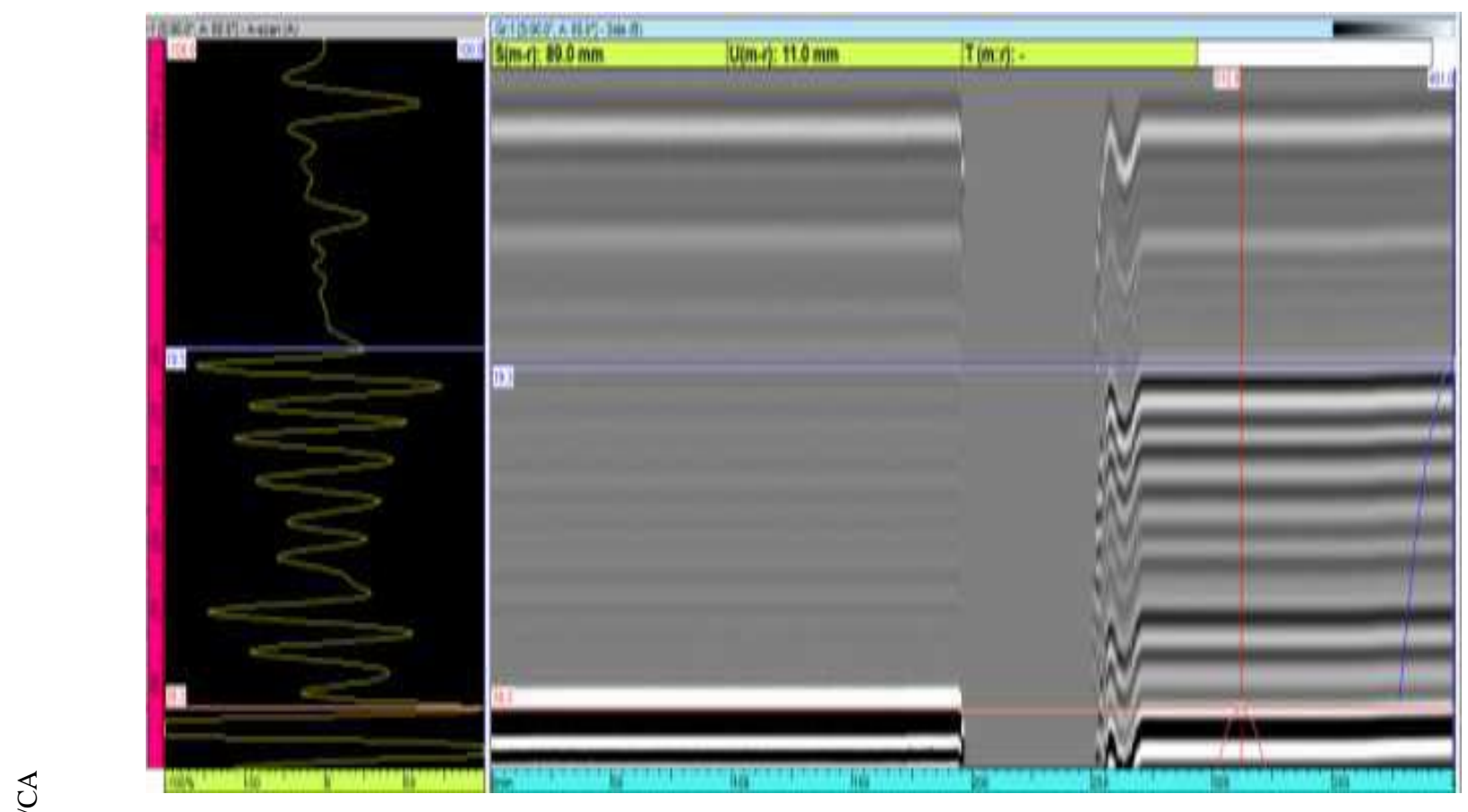

Região de contato: Superfície 2

Altura (h): $10.5 \mathrm{~mm}$

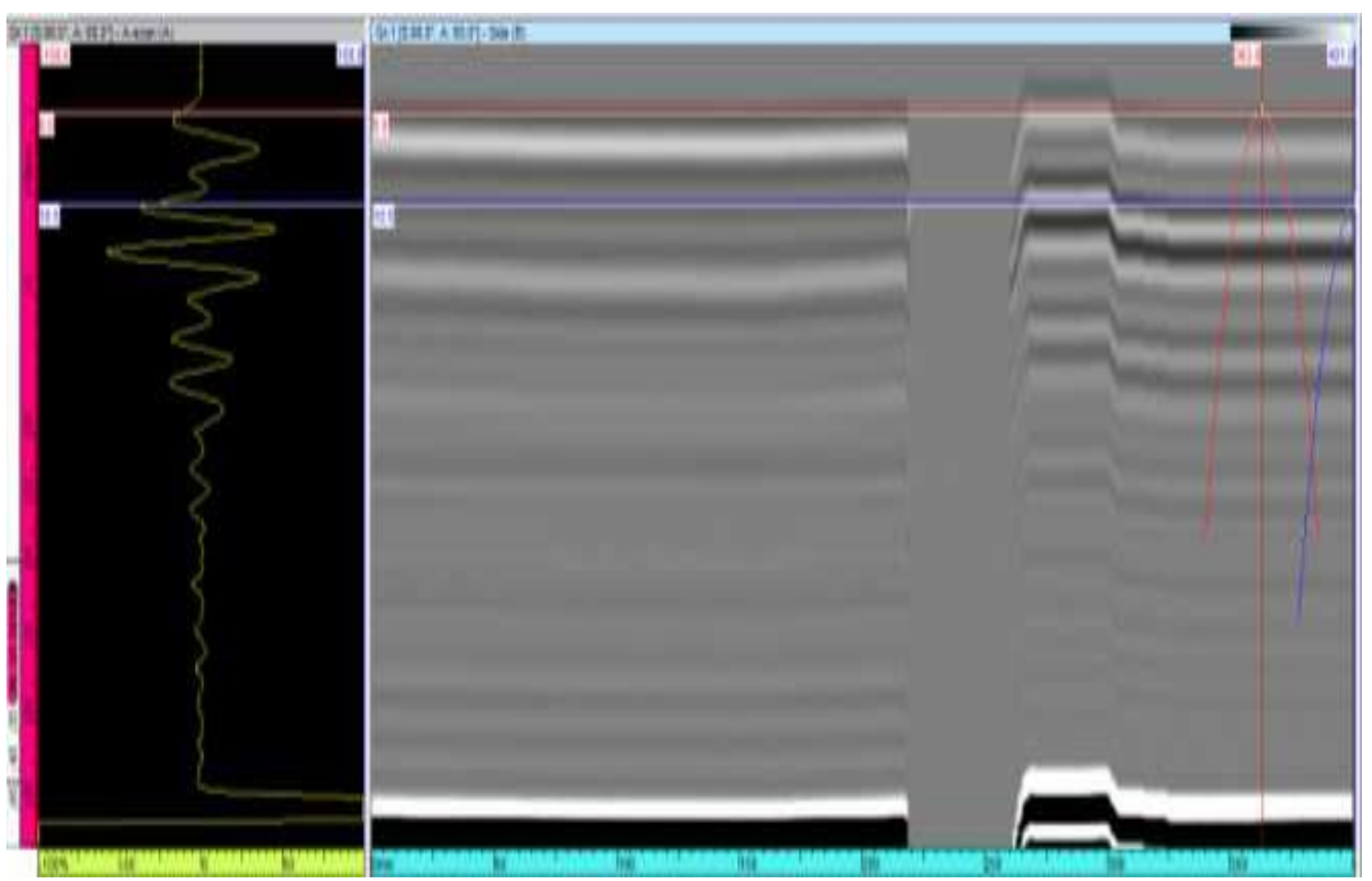


- CP03 - Pulso-Eco

Região de contato: Superfície 1 Lado A

Altura (h): $3.8 \mathrm{~mm}$

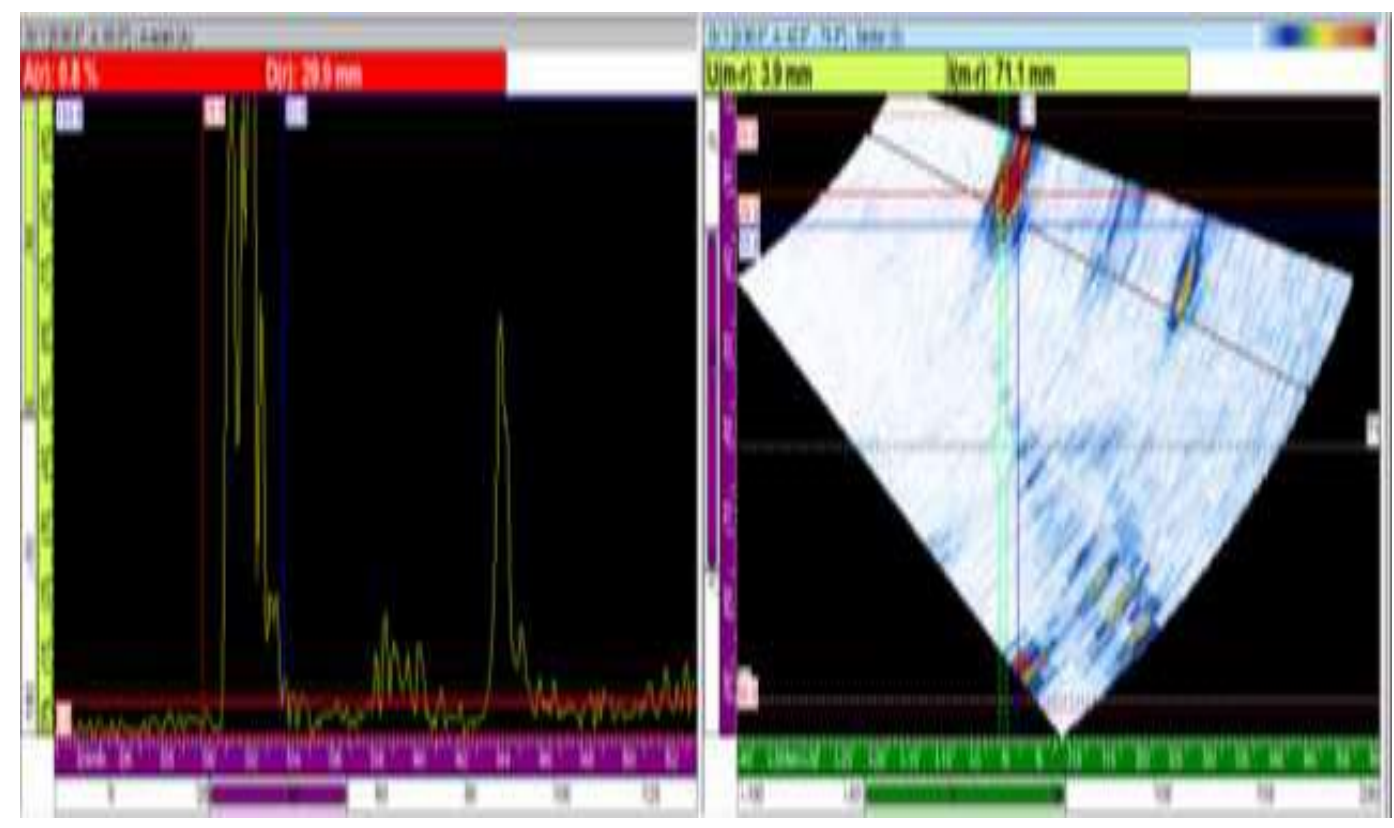

Região de contato: Superfície 1

Lado B

Altura (h): $4.9 \mathrm{~mm}$

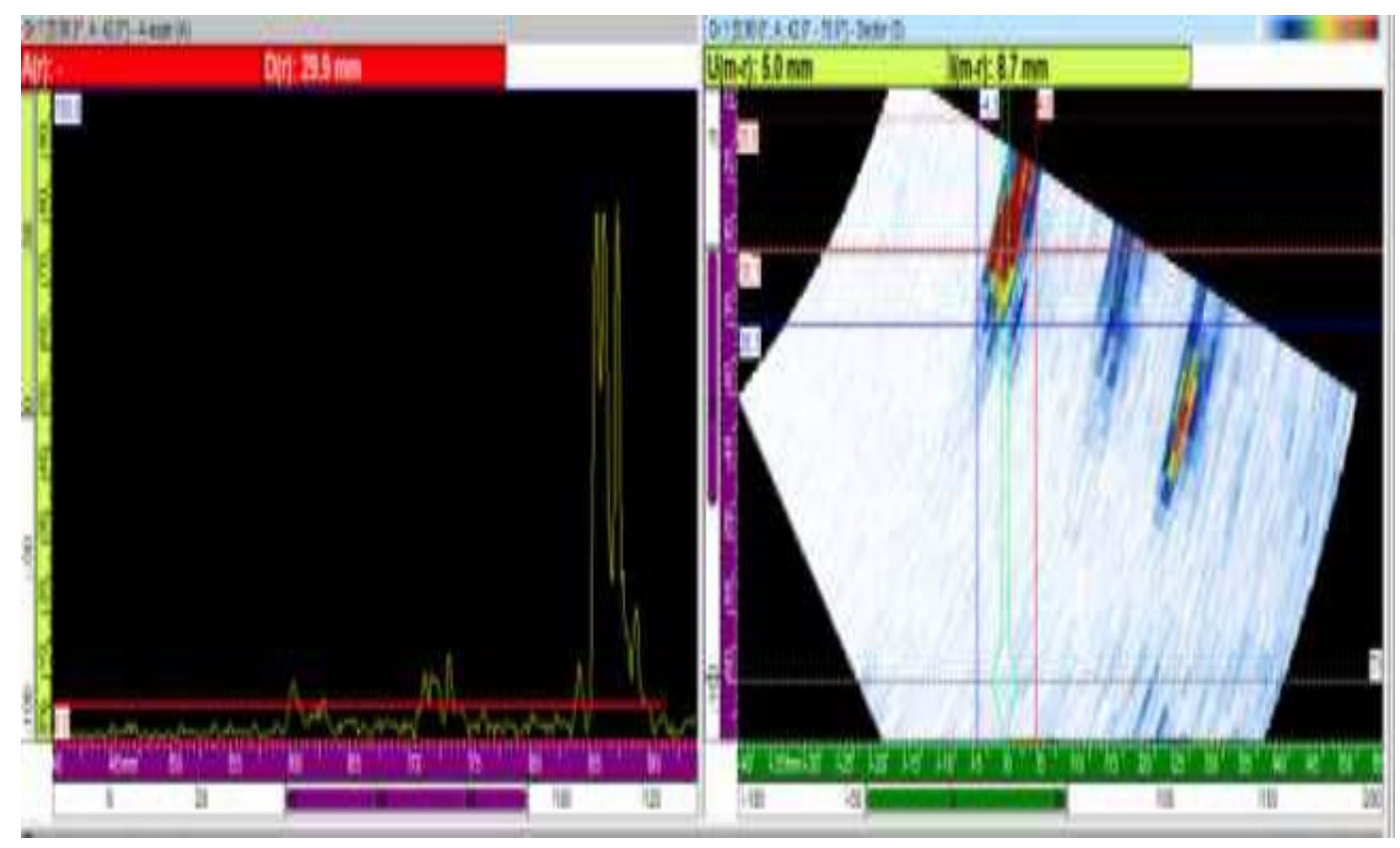


Região de contato: Superfície 2 Lado A

Altura (h): $7.6 \mathrm{~mm}$

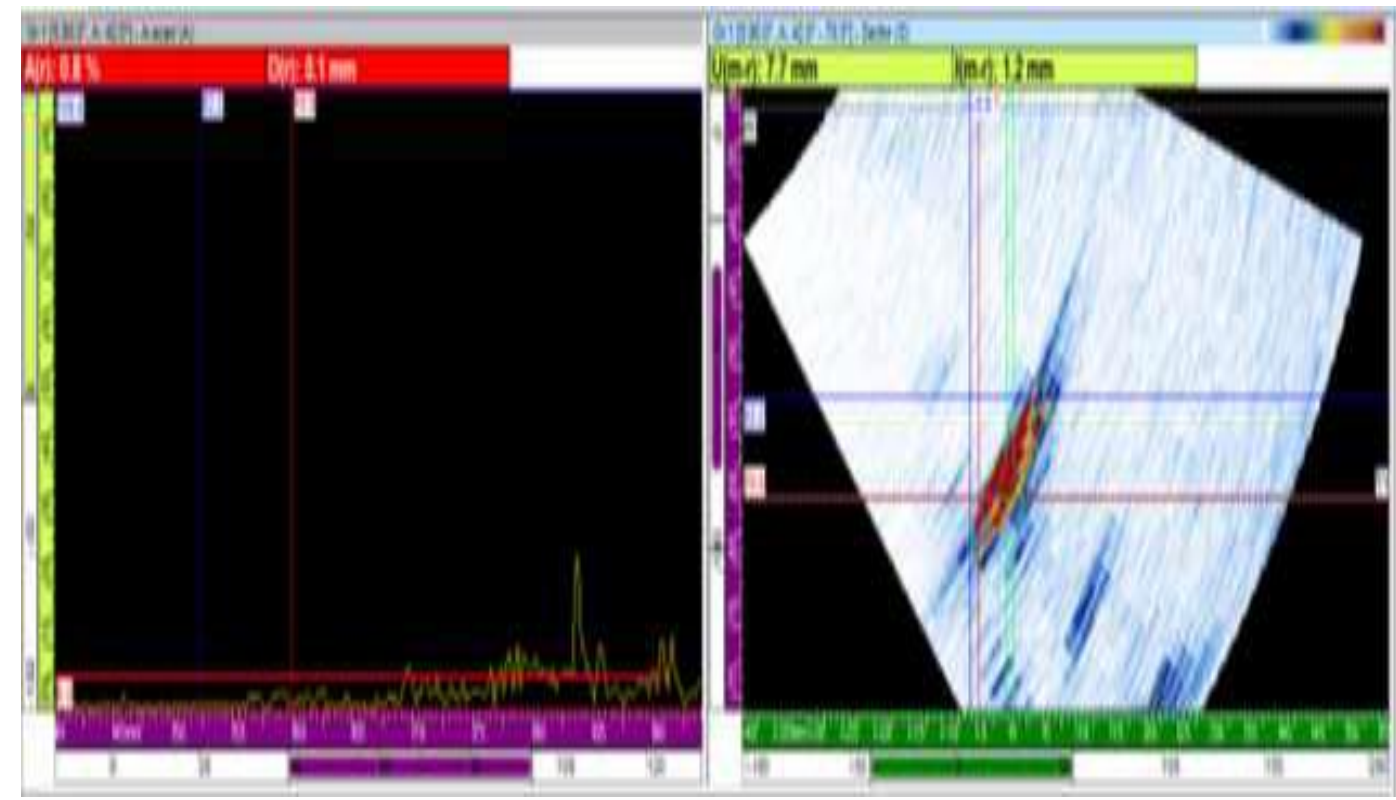

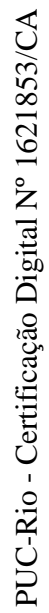

Região de contato: Superfície 2

Lado B

Altura (h): $7.0 \mathrm{~mm}$

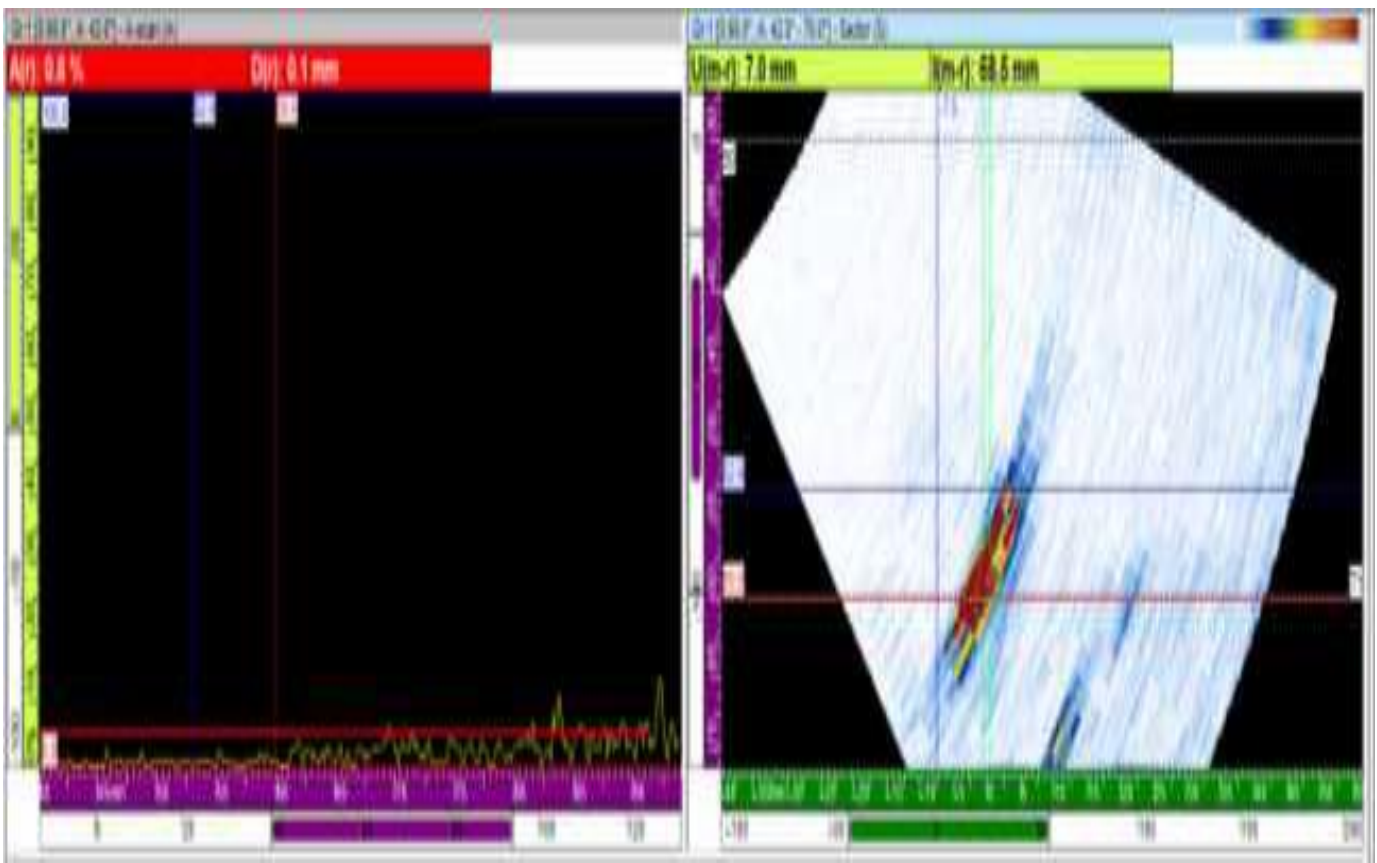


- $\quad$ CP03 - ToFD

Região de contato: Superfície 1

Altura (h): $7.2 \mathrm{~mm}$

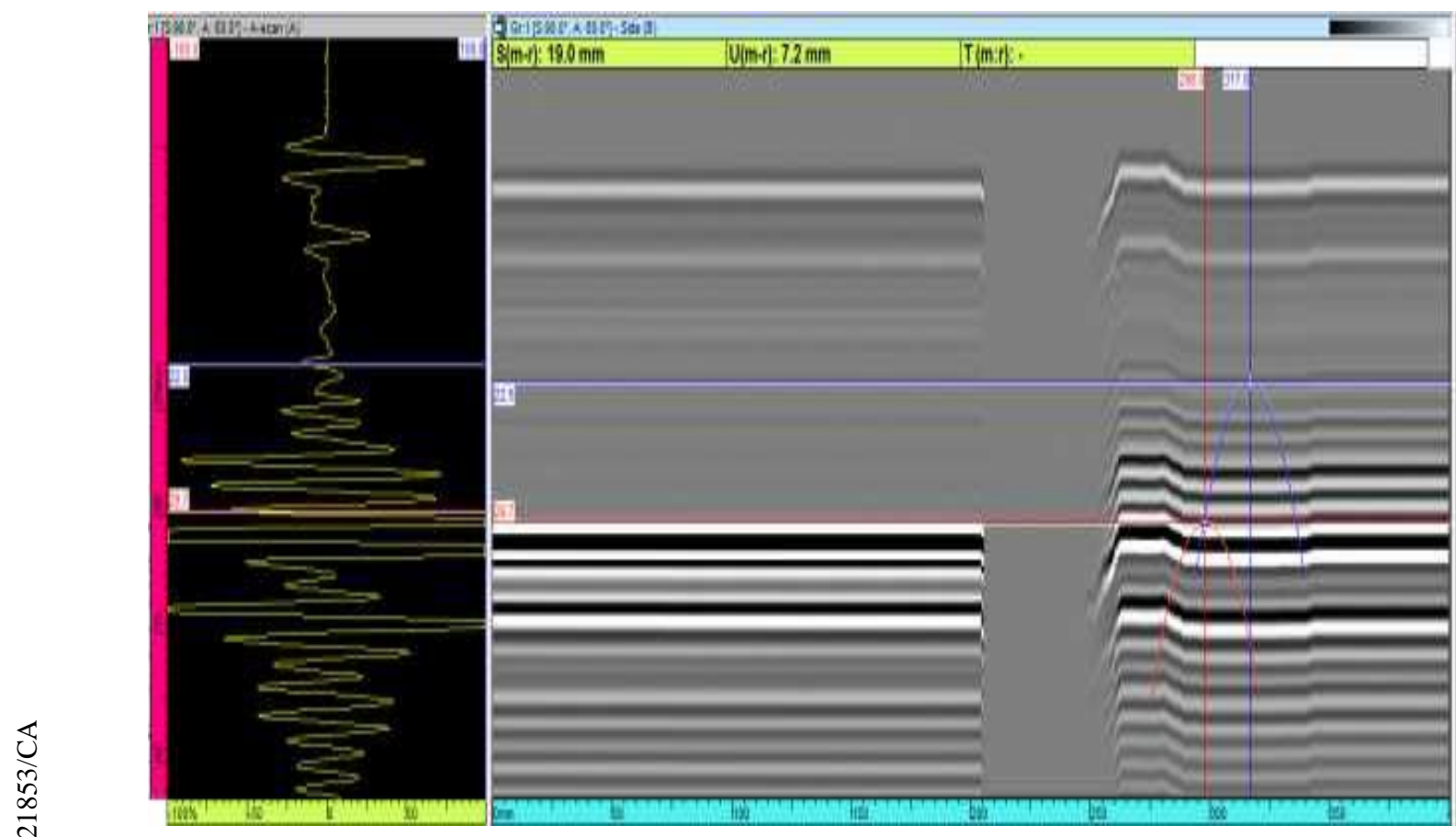

Região de contato: Superfície 2

Altura (h): $5.3 \mathrm{~mm}$

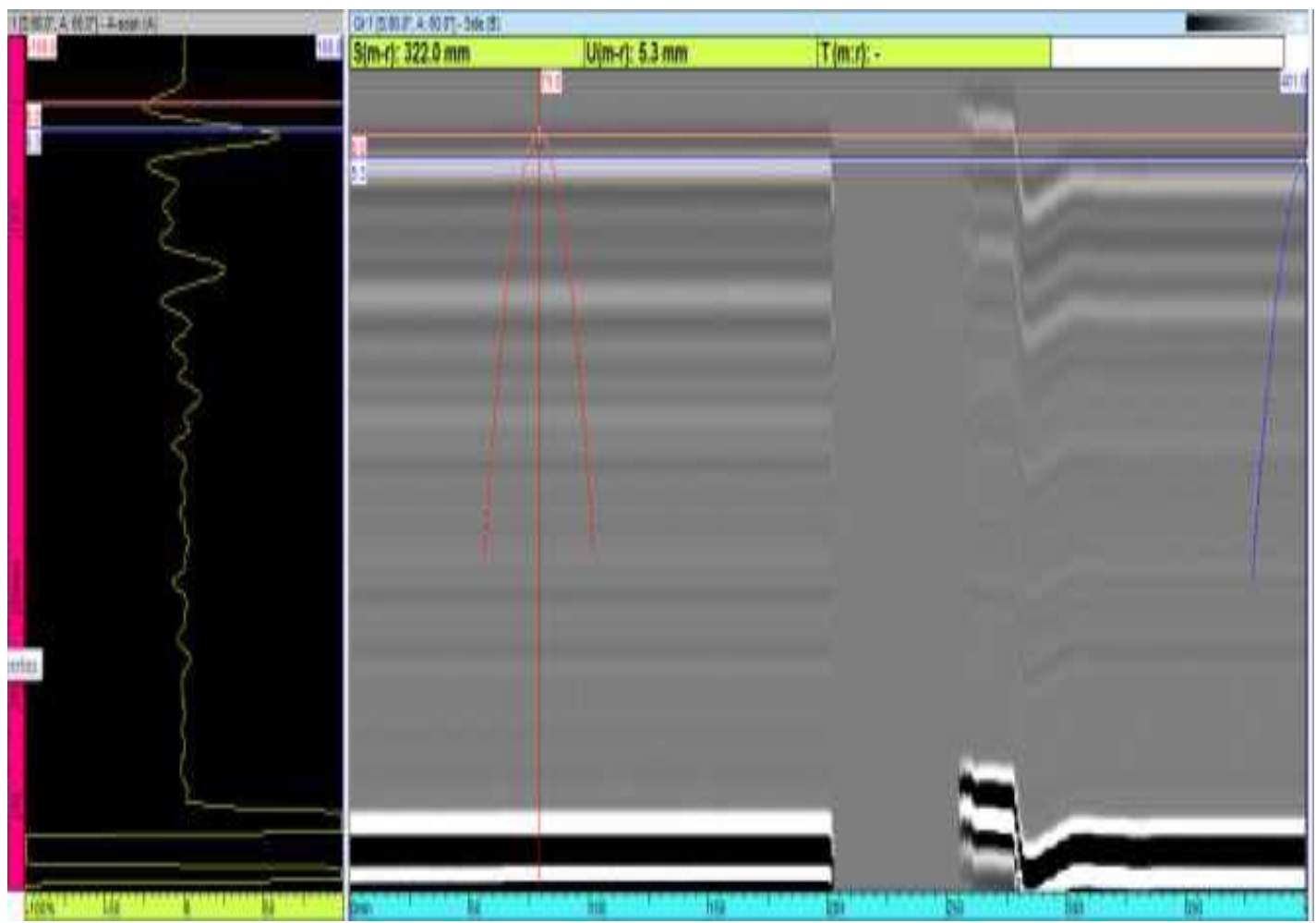


- CP04 - Pulso-Eco

Região de contato: Superfície 1 Lado A

Altura (h): $17.0 \mathrm{~mm}$

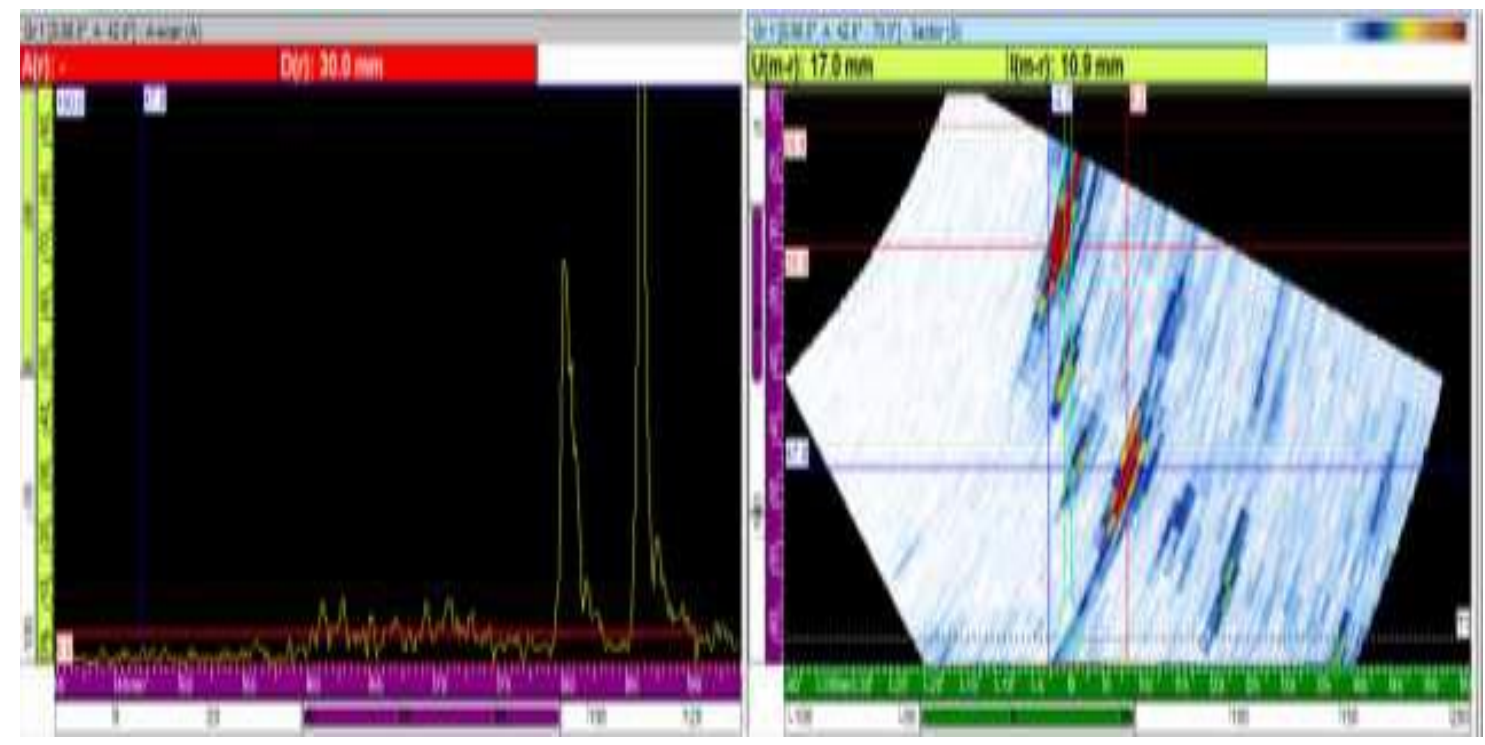

Região de contato: Superfície 1 Lado B

Altura (h): $18.6 \mathrm{~mm}$

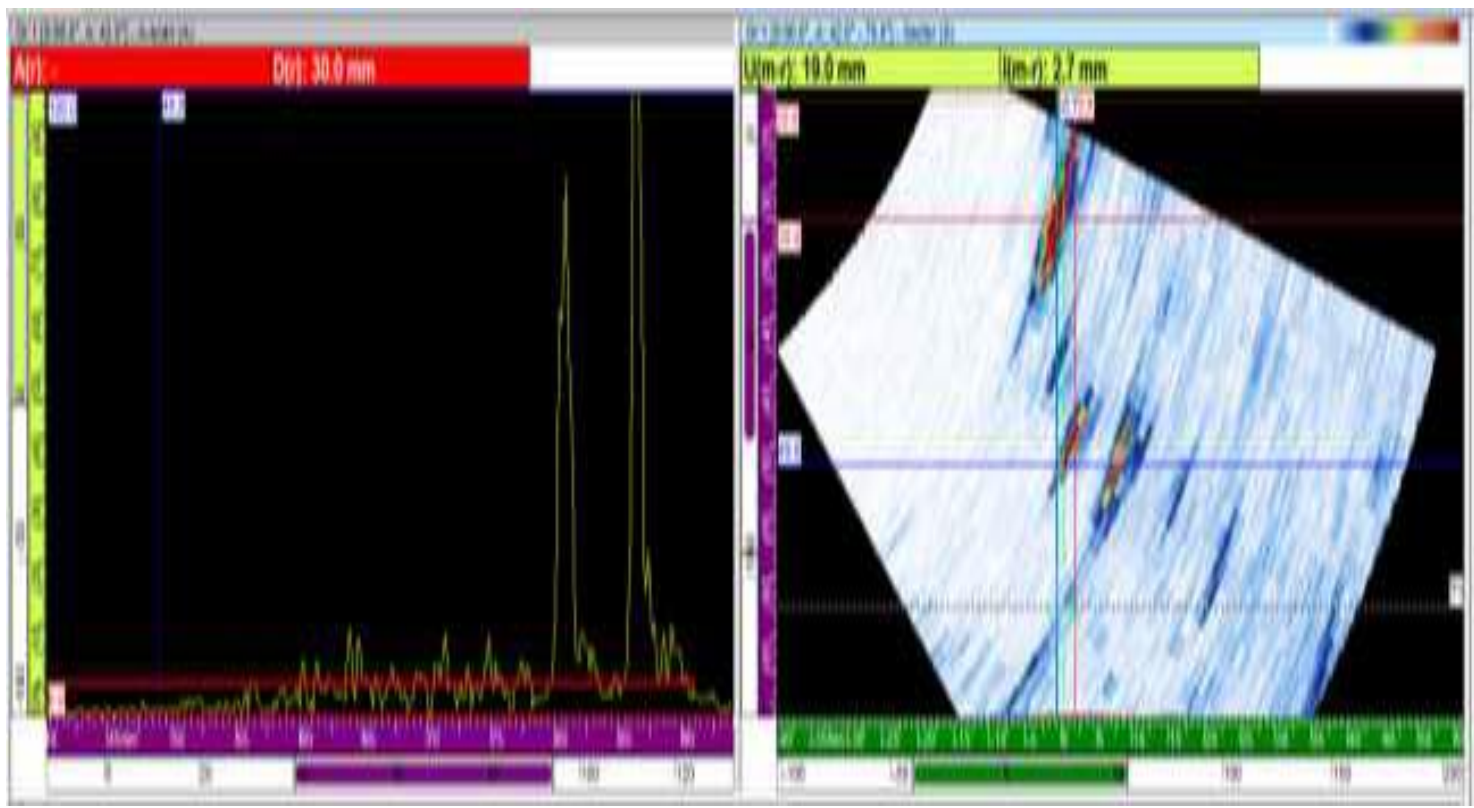


Região de contato: Superfície 2 Lado A

Altura (h): $18.9 \mathrm{~mm}$

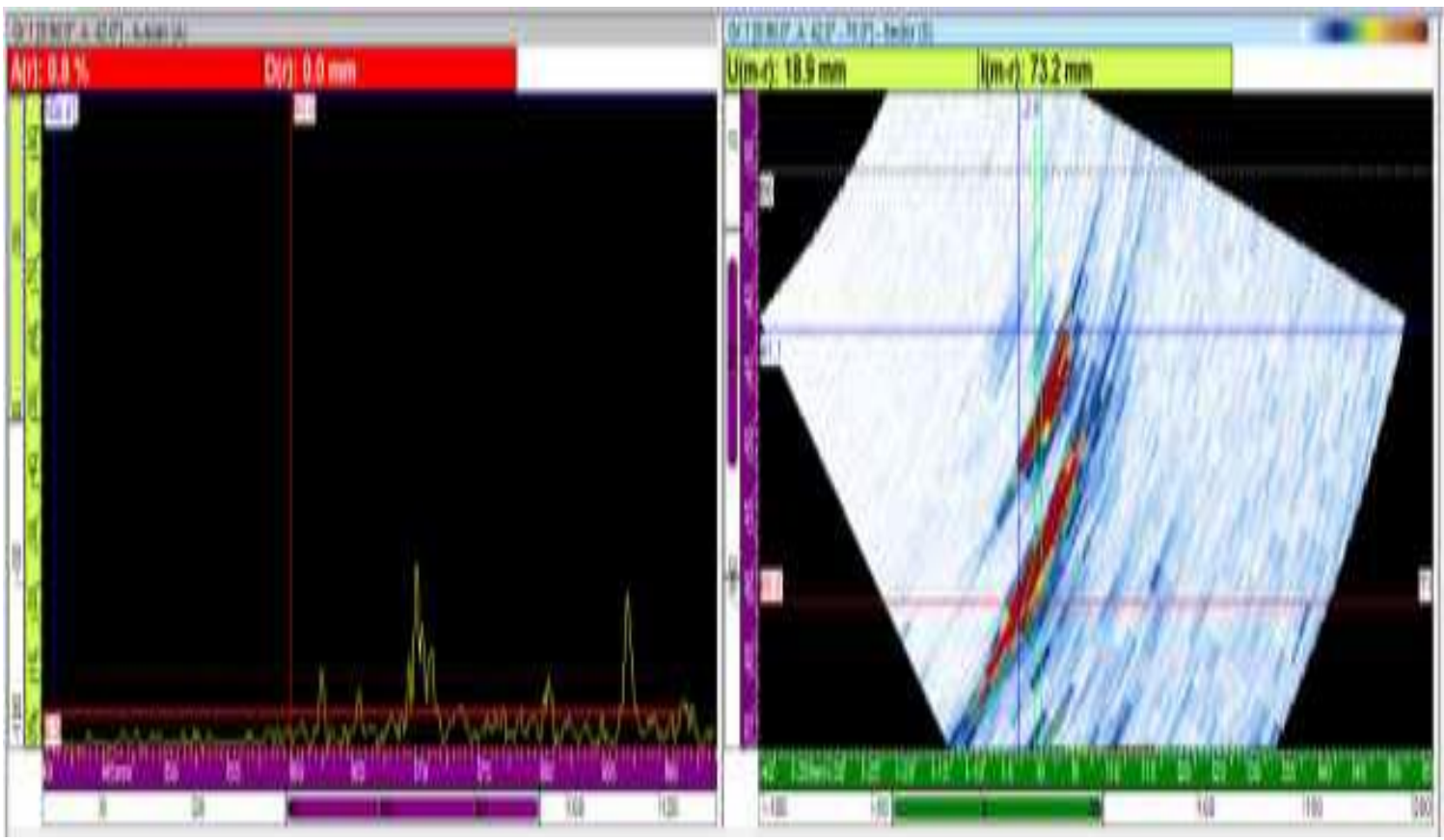

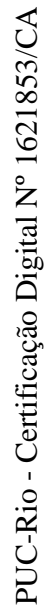

Região de contato: Superfície 2

Lado B

Altura (h): $19.0 \mathrm{~mm}$
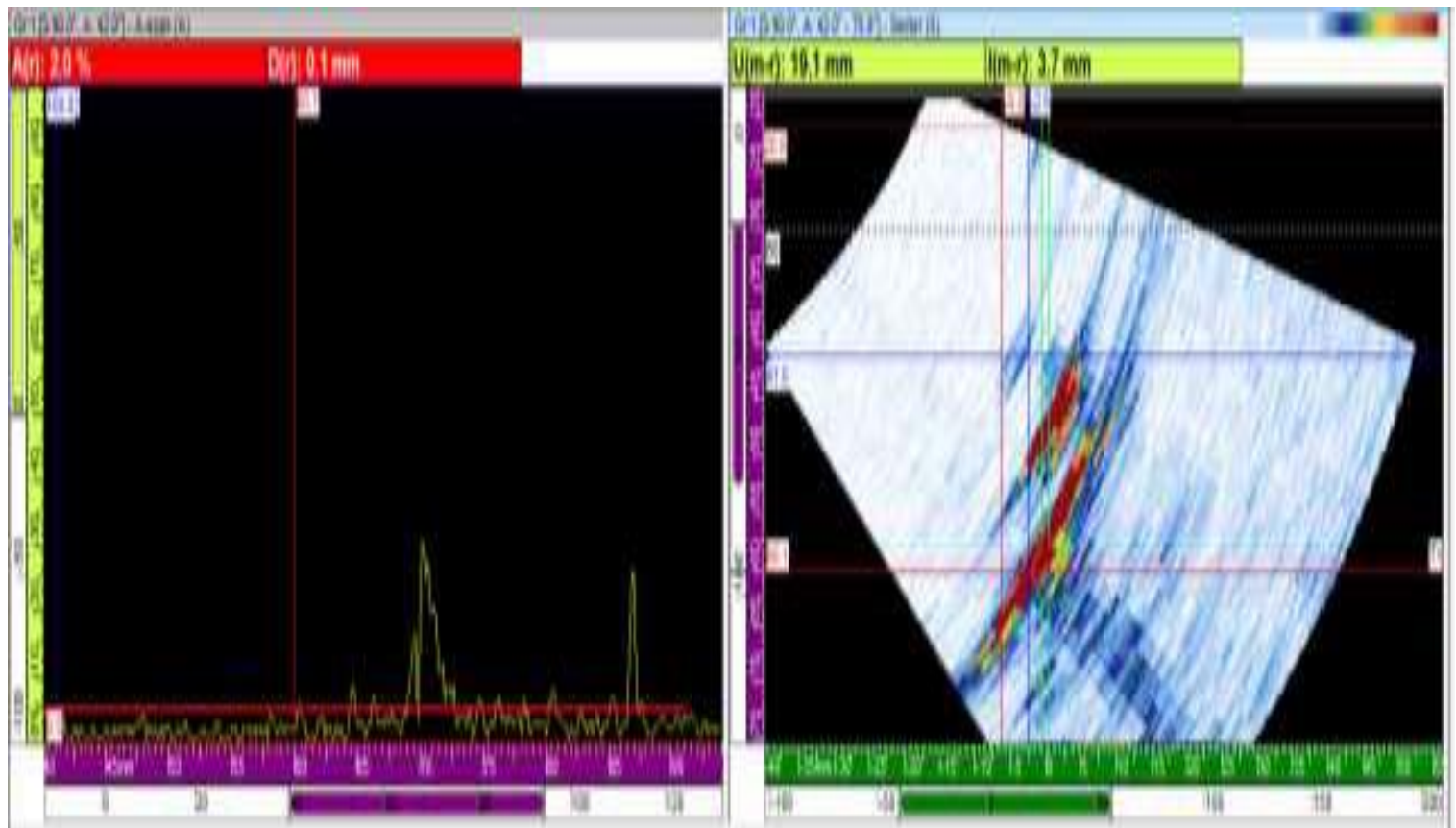
- $\quad$ CP03 - ToFD

Região de contato: Superfície 1

Altura (h): $17.9 \mathrm{~mm}$

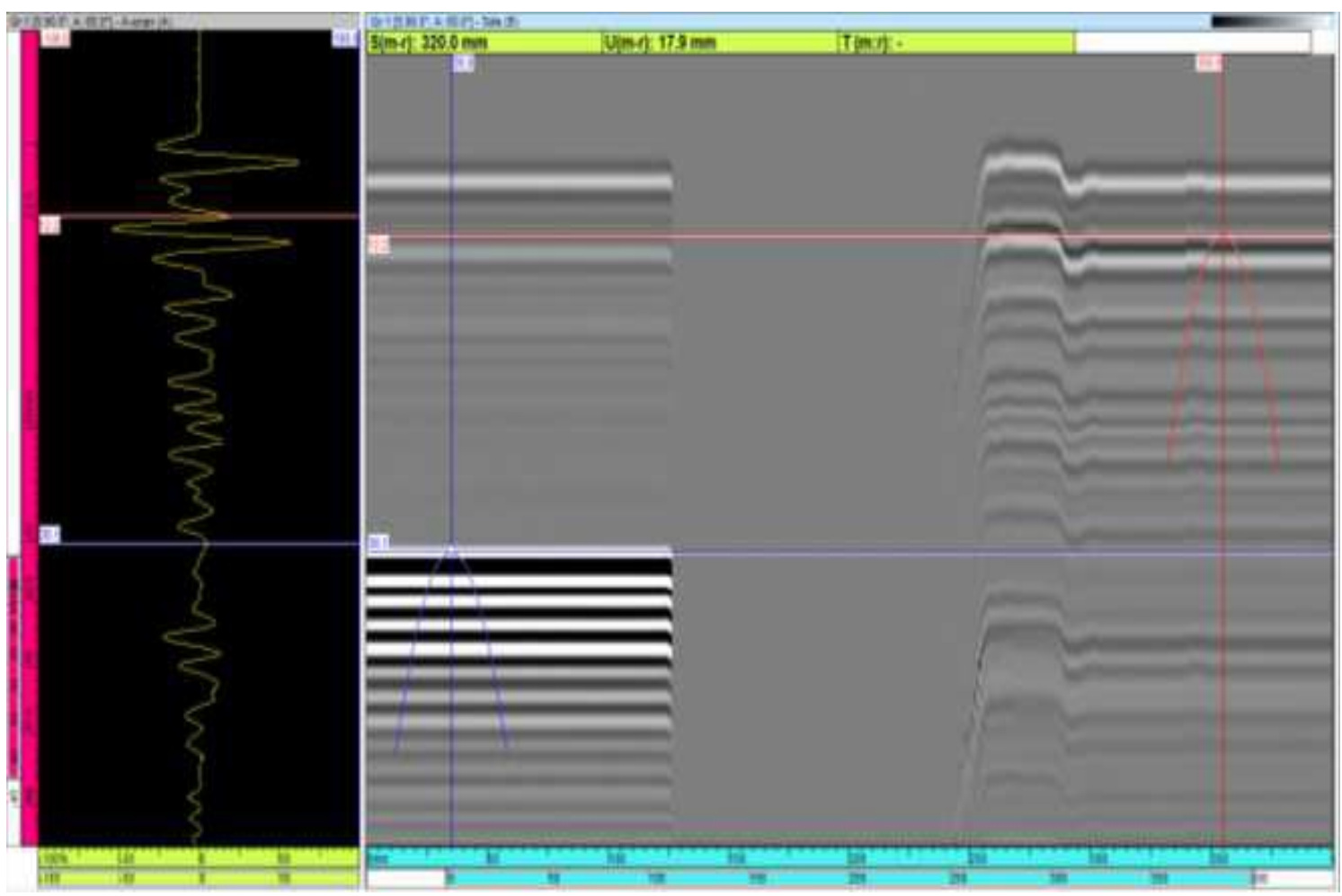

Região de contato: Superfície 2

Altura (h): $18.3 \mathrm{~mm}$

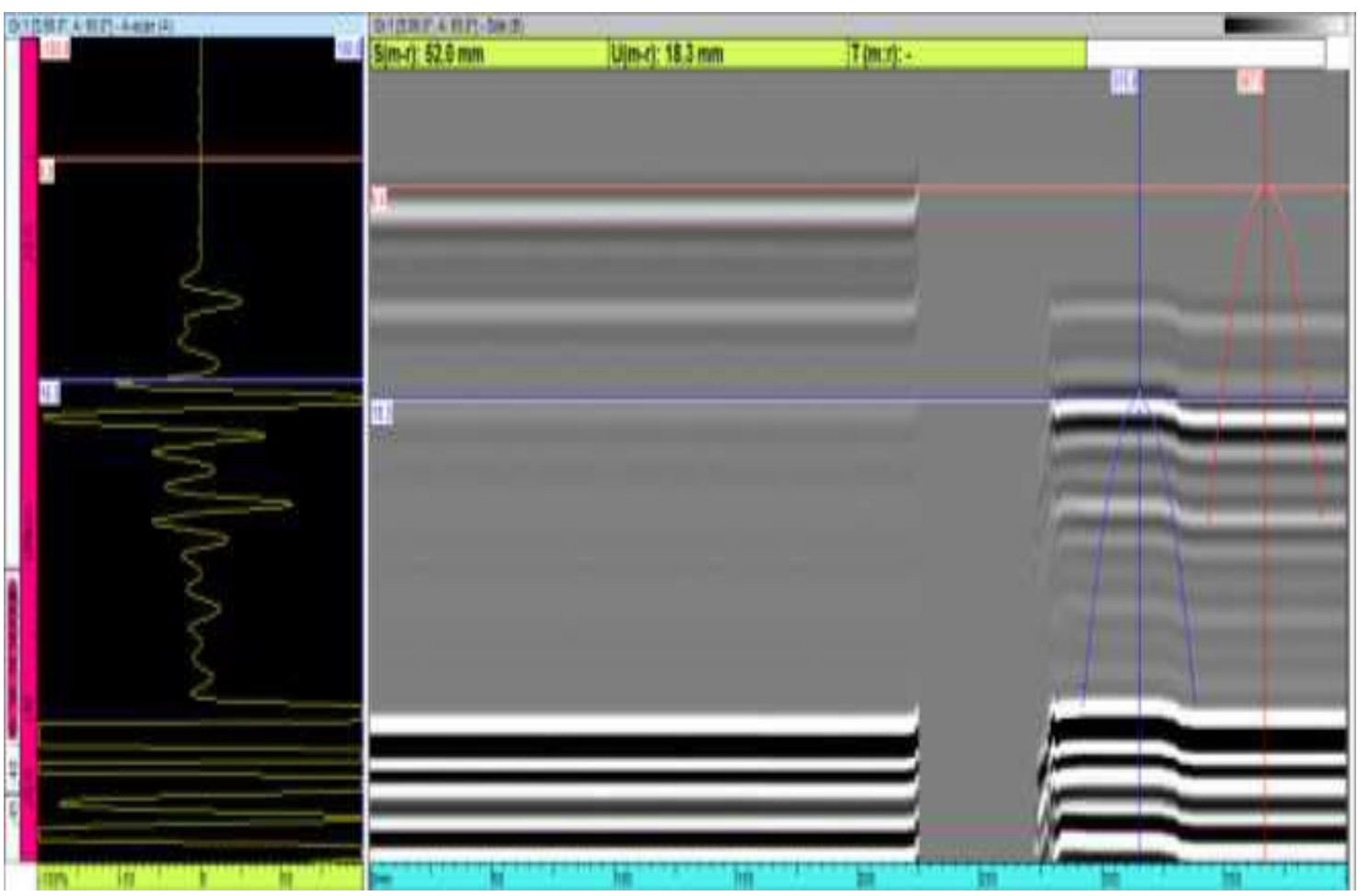


Anexo 03 - Resultados da RD:

- CP01

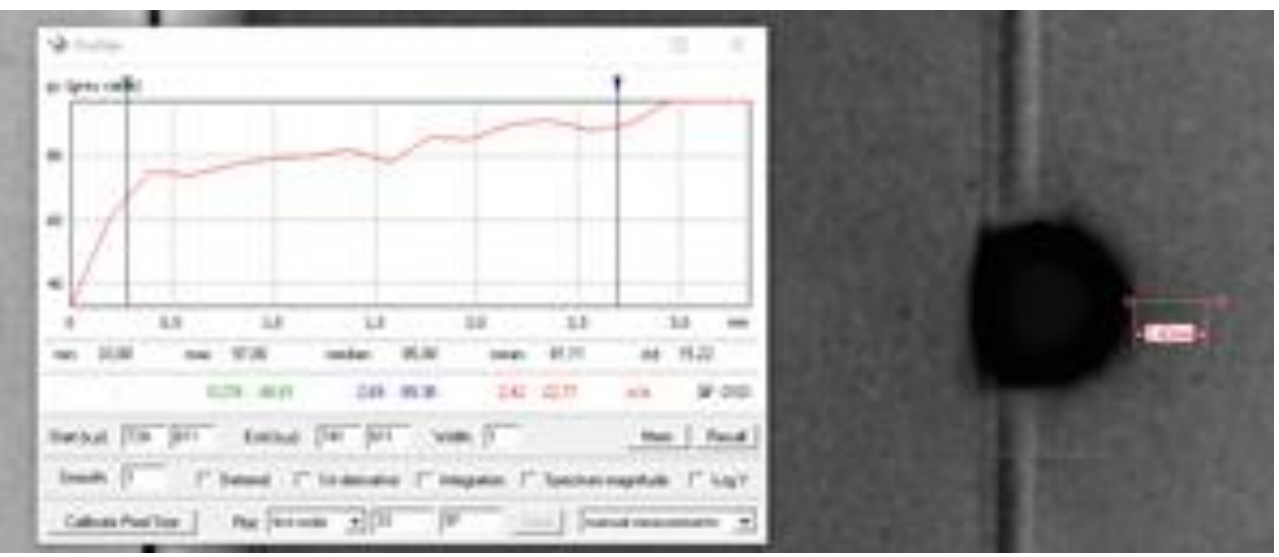

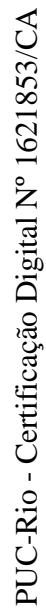

- $\mathrm{CP02}$

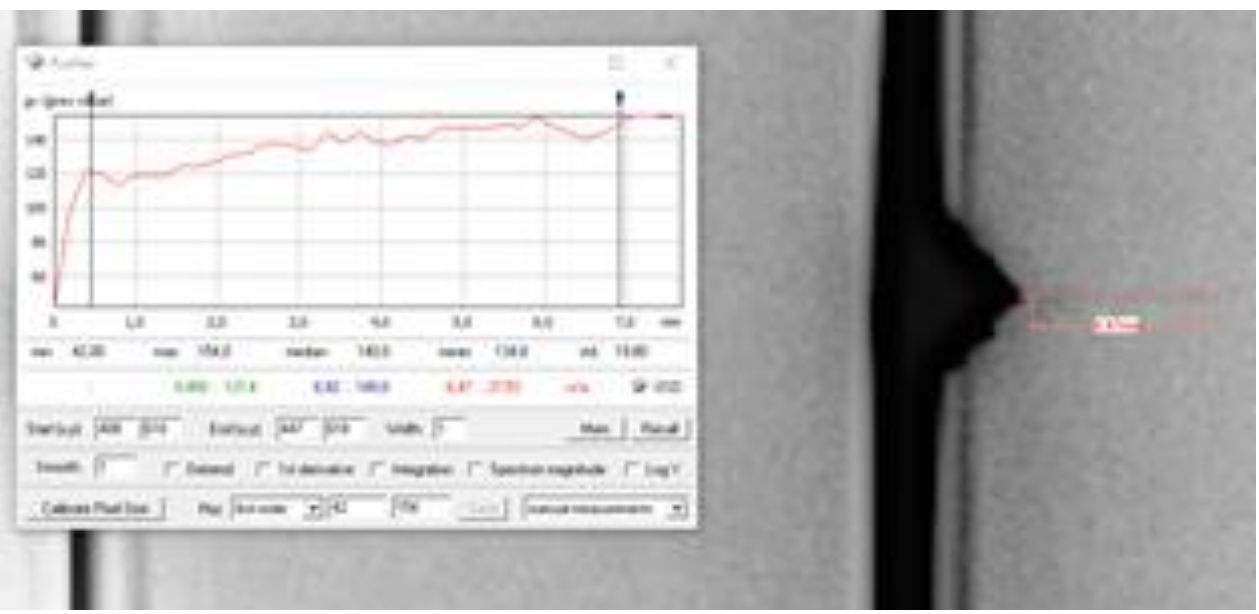


- $\mathrm{CP03}$

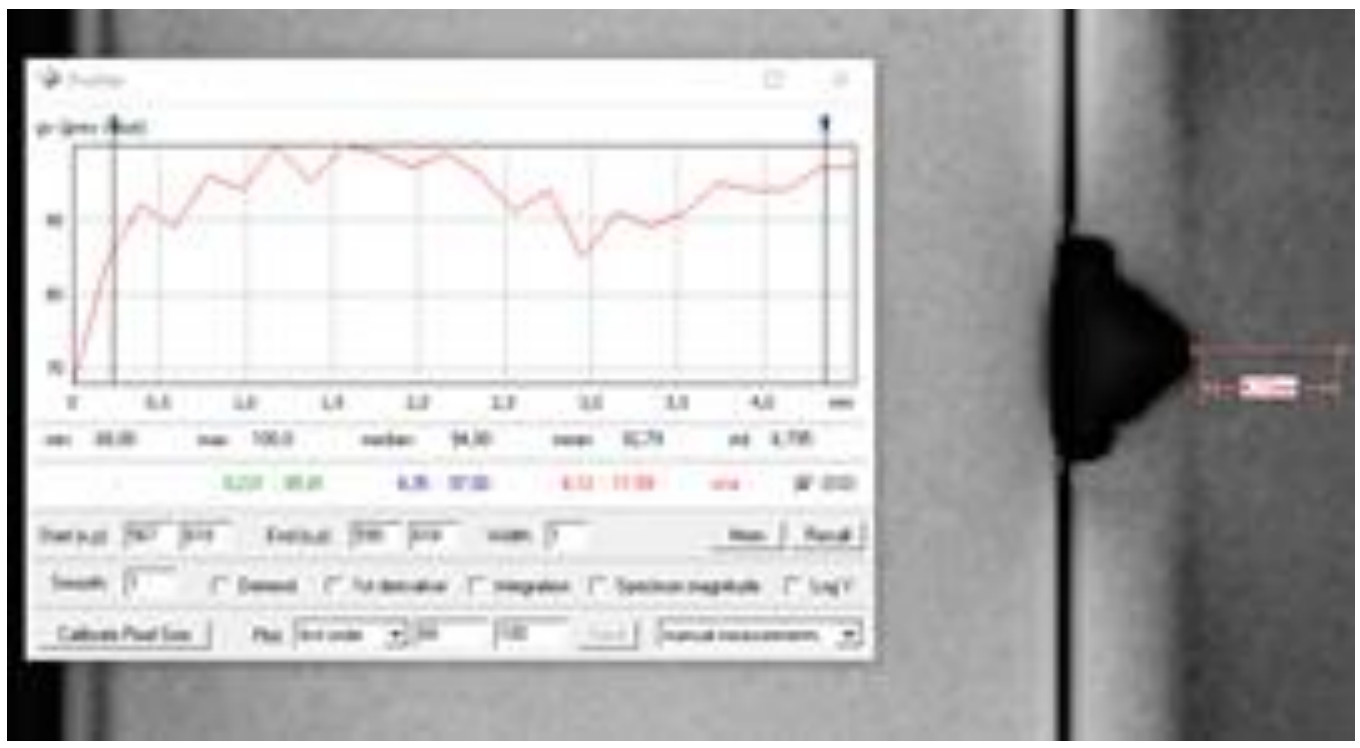

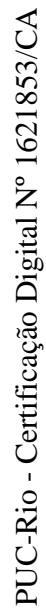

- CP04
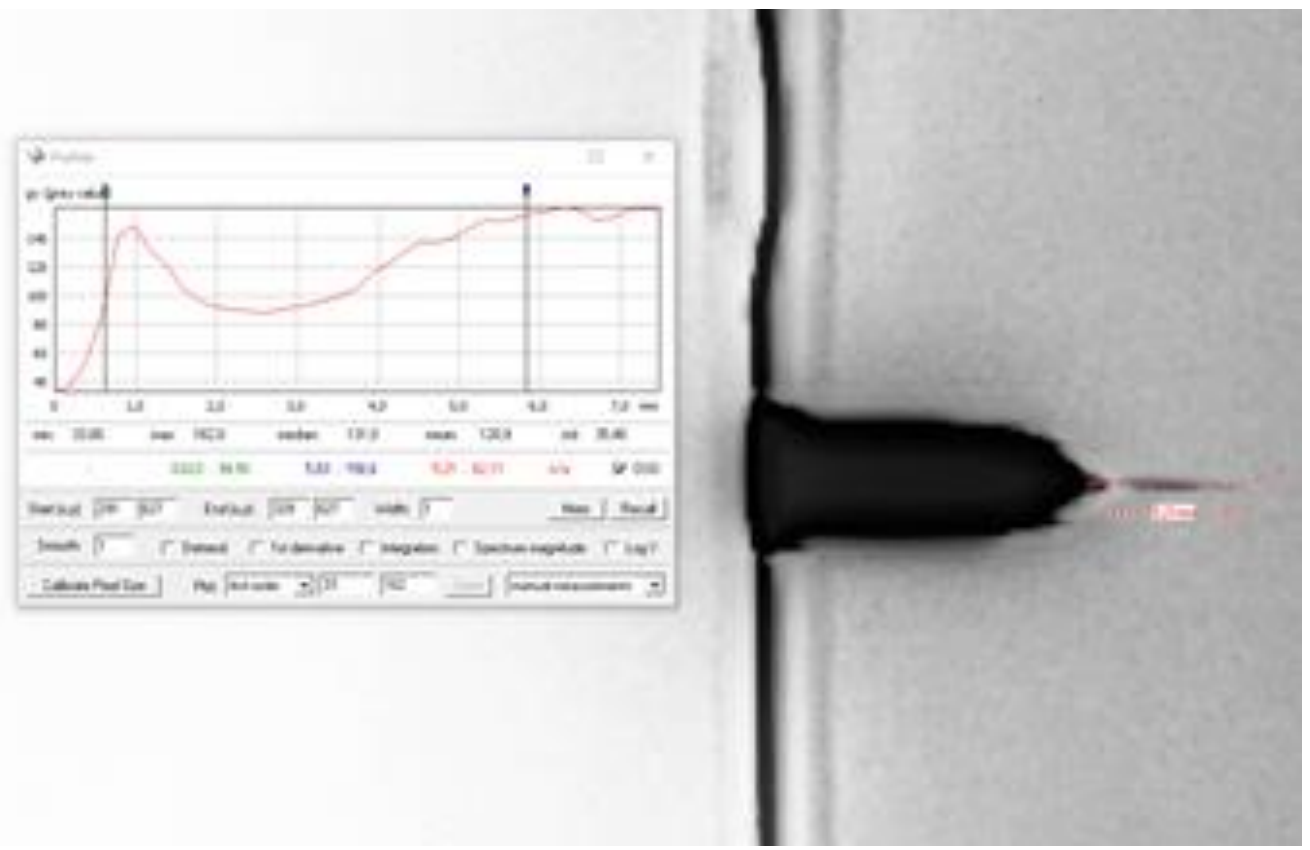
Anexo 04 - Resultados da TC:

- CP01

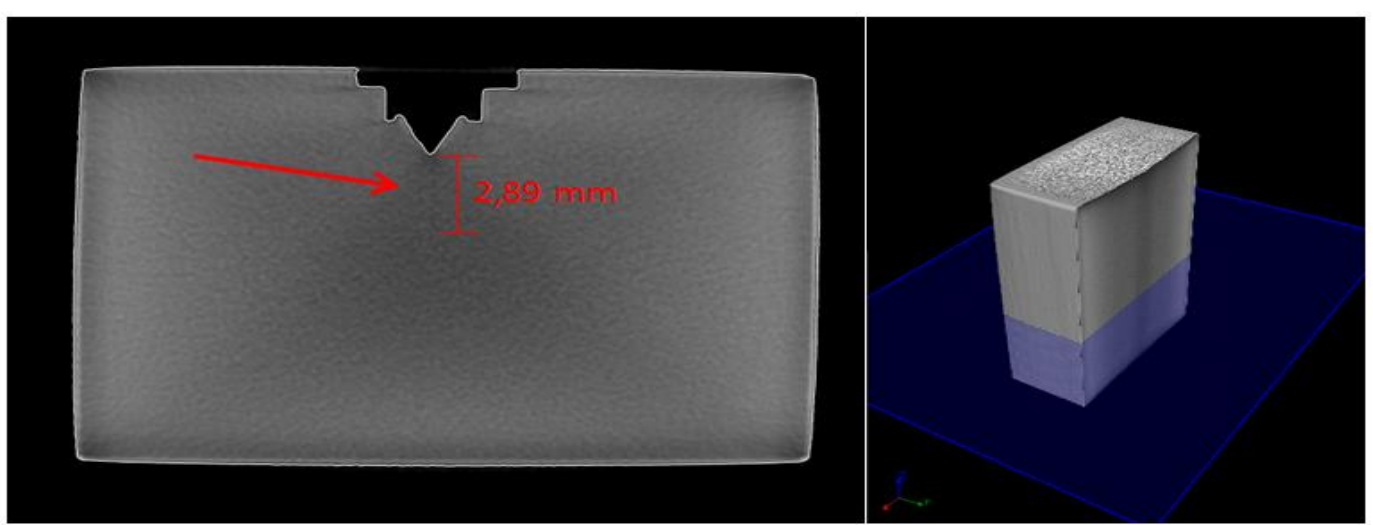

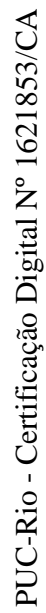
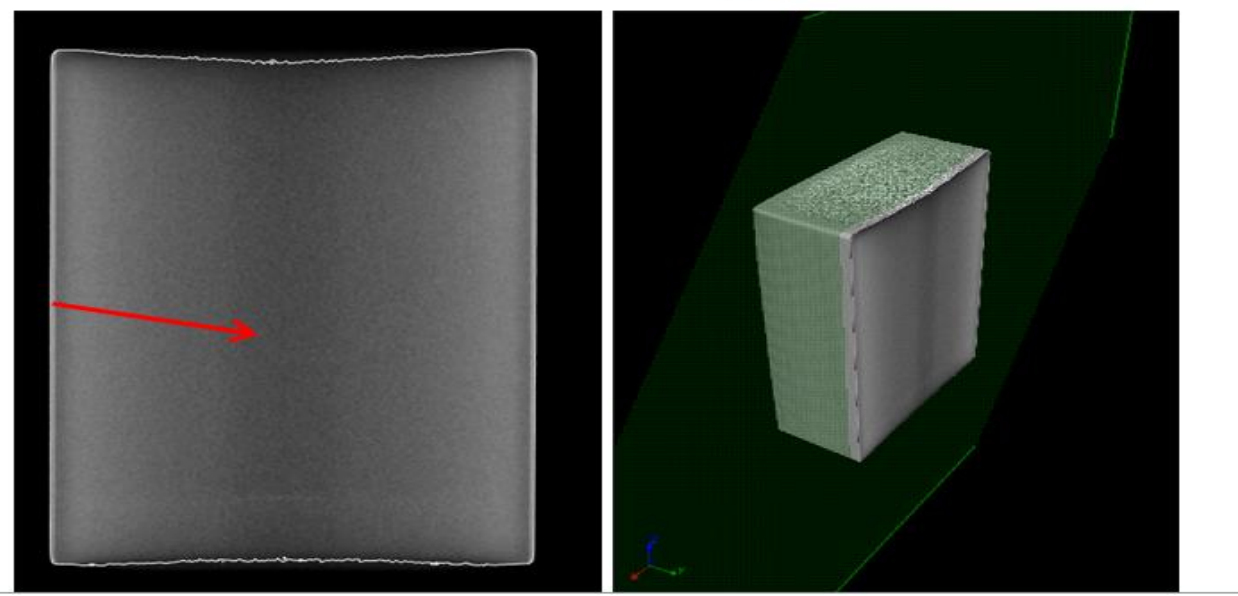
- $\mathrm{CP02}$
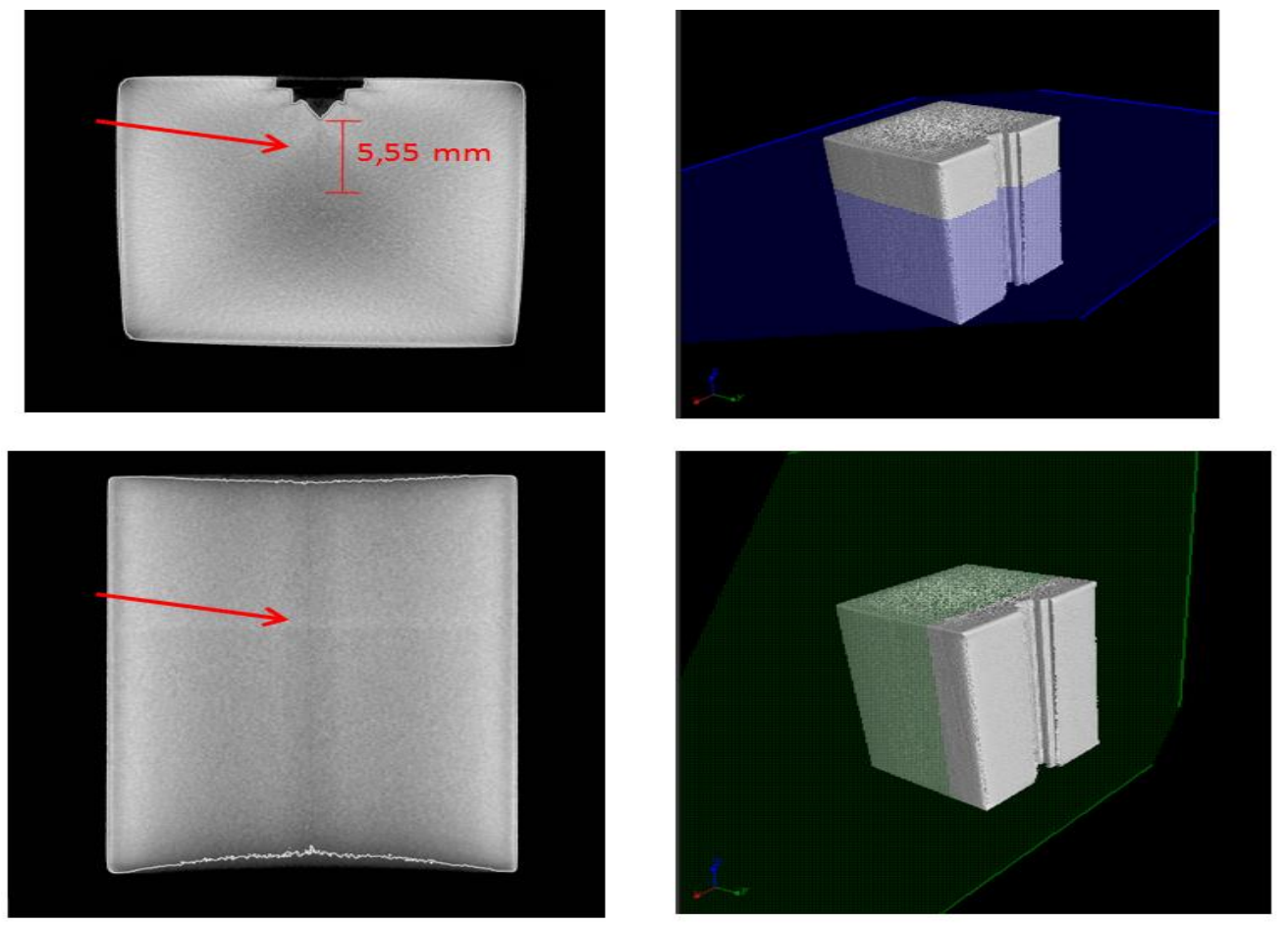

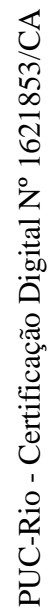

- $\mathrm{CP03}$
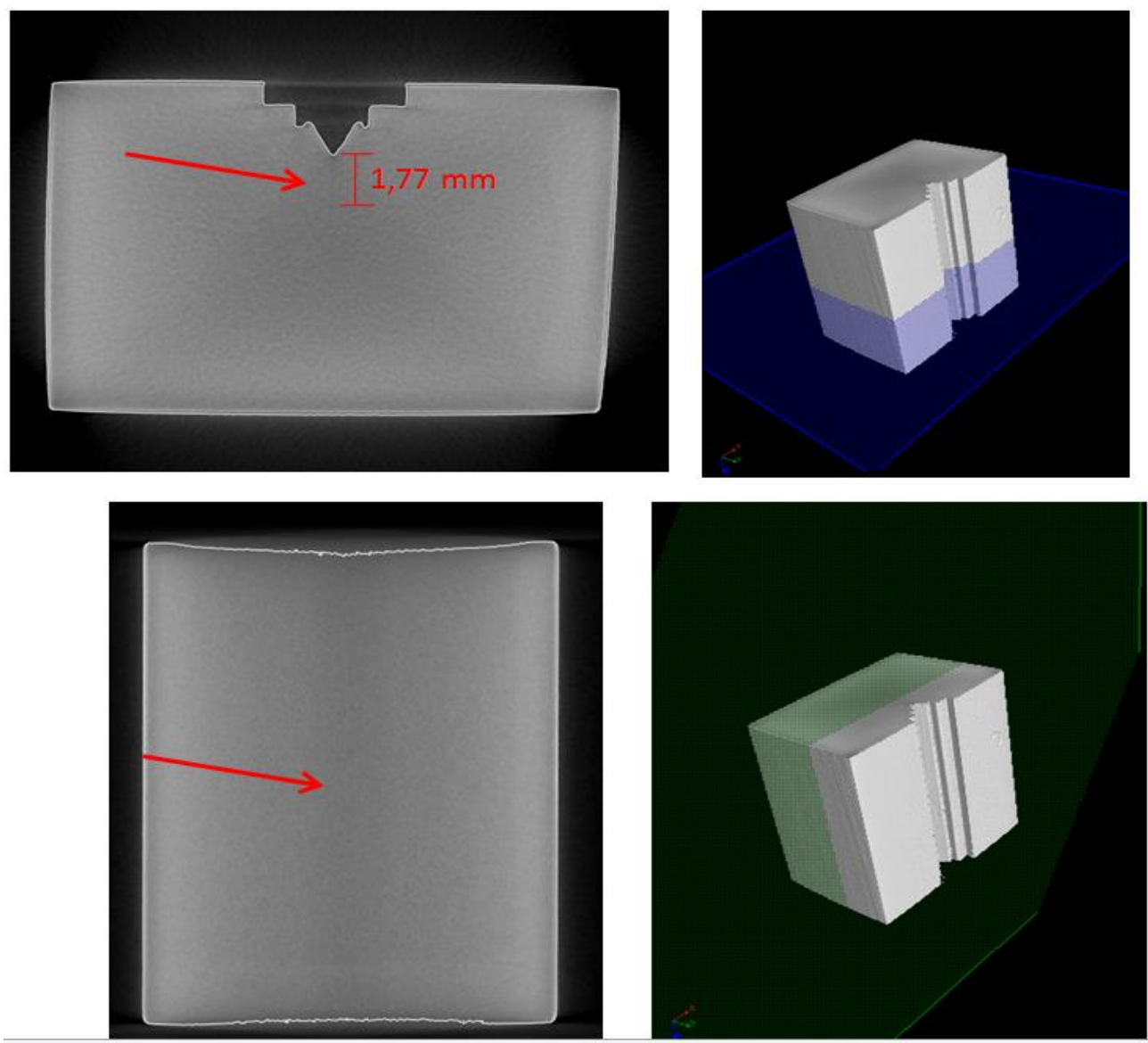


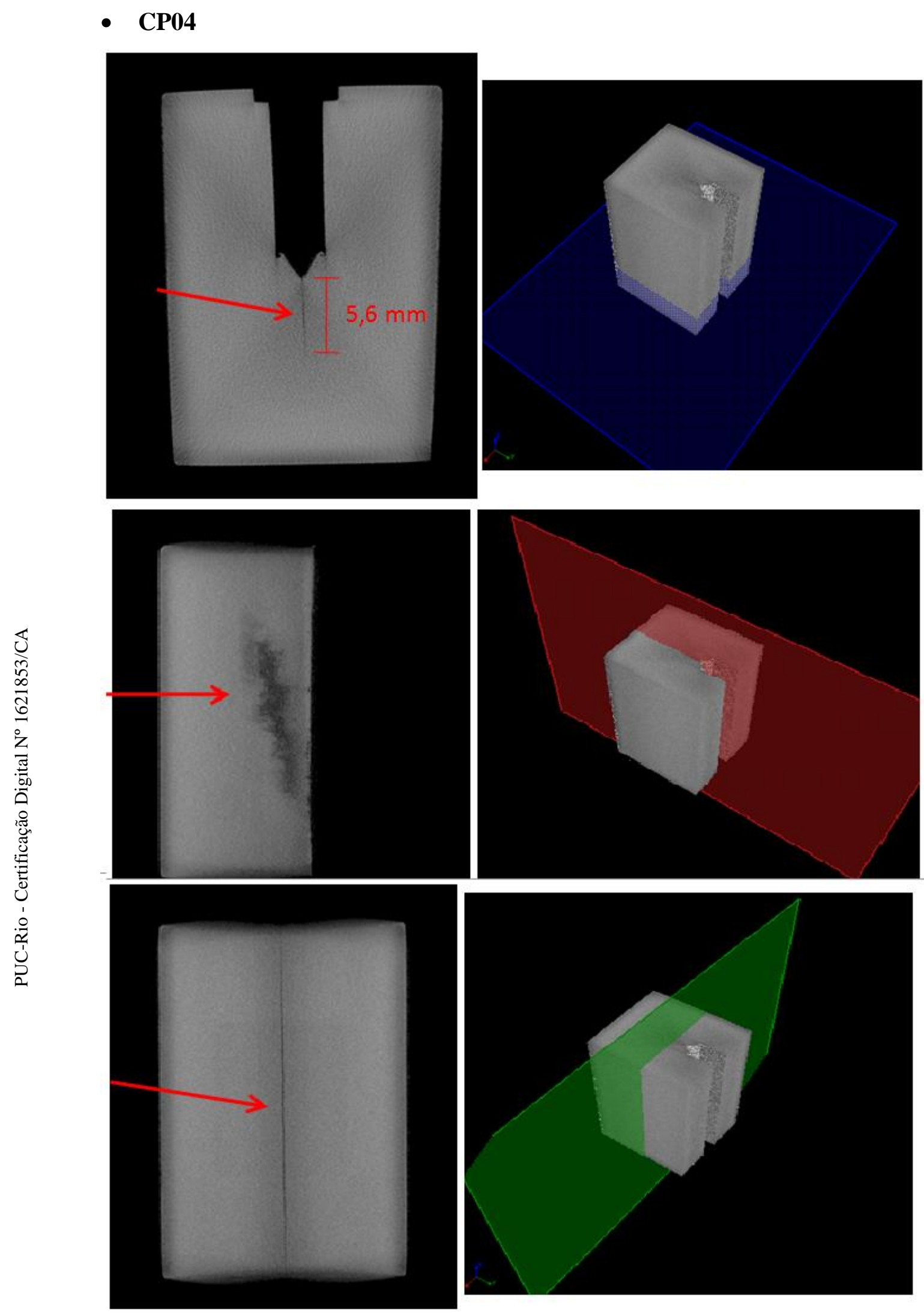

